\title{
THE JURY'S ROLE IN DECIDING NORMATIVE ISSUES IN THE AMERICAN COMMON LAW
}

\author{
Mark P. Gergen*
}

TABLE OF CONTENTS

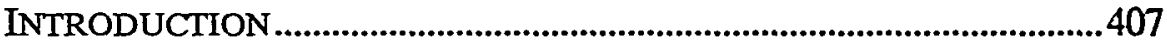

I. THE HISTORIC ROLE OF THE COMMON LAW JURY ..............417

II. PHYSICAL OR PERSONAL TORTS .............................................424

A. Negligence .................................................................................424

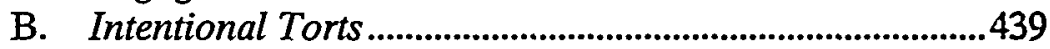

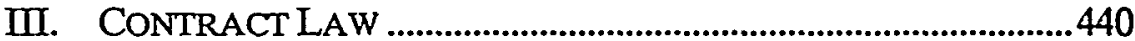

A. Classical Contract Law ...................................................442

B. Standards of Fair Dealing .....................................................451

IV. ECONOMIC TORTS AND RESTITUTION ...................................461

A. Improper Interference ............................................................463

B. Unjust Enrichment ...............................................................468

V. ABUSE OF CONFIDENTIAL RELATIONSHIP ..............................475

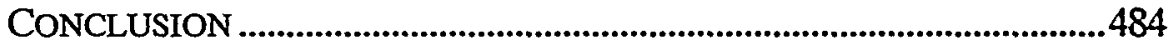

\section{INTRODUCTION}

TMAGINE that you have been given a scale and the task to use that scale to derive the values that underlie the division of power between judge and jury to decide normative issues in the American common law. You would probably start by putting on the scale the familiar costs and benefits of rules and standards.' These go on the

* Much of this Article is based on conversations with colleagues, including David Anderson, Steve Goode, Douglas Laycock, Sandy Levinson, Richard Markovits, William Powers, Alan Rau, David Robertson, Charles Silver, Steve Smith (now at McGill), Patrick Woolley, and Charles Alan Wright. An earlier version was presented at a workshop at Northwestern University School of Law.

1. This article defines rules and standards in the usual way. The following definition is typical: "Rules are legal norms that are formal and mechanical. They are triggered by a few easily identified factual matters and are opaque in application to the values they are designed to serve. Standards, on the other hand, are flexible, context-sensitive legal norms that require evaluative judgments in their application." Larry Alexander \& Ken Kress, Against Legal Principles, 82 Iowa L. Rev. 739, 740 (1997). Some commentators insist on a further division between standards that 
specify a value or goal and ask the decision-maker to administer the standard consistent with that value or goal, and those that leave it to the decision-maker to choose among diverse and sometimes conflicting values or goals. See Richard A. Posner, Reply to Critics of the Problematics of Moral and Legal Theory, 111 Harv. L. Rev. 1796, 1802-04 (1998) [hereinafter Posner, Reply]. Judge Learned Hand's definition of negligence (B < PL), see United States v. Carroll Towing Co., 159 F.2d 169,173 (2d Cir. 1947), is an example of a standard that seems predicated upon a fixed goal, see Posner, Reply, supra, at 1808, while the common form of jury instruction on the standard of care in negligence (the reasonably prudent person standard) is an example of a standard that allows the decision-maker to choose moral criteria. See infra part II.A. Posner's point raises the possibility of a standard that is administered on a scientific basis, thus calling into question the identification of standards with moral or value judgments. This raises questions about the meaning of moral or value judgments. A mechanical standard that leaves the decision-maker no choice regarding relevant values or their weight might better be labeled a "formula" to distinguish it from a standard requiring a value judgment. It is a gross misunderstanding of the law of negligence to claim that the standard of the reasonably prudent person can be reduced to the Hand formula without losing something vital.

P.S. A tiyah and Robert S. Summers distinguish highly formal or "hard and fast" rules and flexible rules, rather than rules and standards. See P.S. Atiyah \& Robert S. Summers, Form and Substance in Anglo-American Law: A Comparative Study of Legal Reasoning, Legal Theory, and Legal Institutions 71 (1987). There is considerable virtue in their terminology because it avoids giving the impression that there is a bright-line distinction between formal and flexible legal commands. By flexible rules the authors mean those where moral or value judgments-"substantive reasons"-are made at the point of application. See id. at 5-6,71,75.

Distinguishing rules and standards, as I do, by whether they involve factual or moral/value judgments, rather than by discretion or uncertainty in the judgment, is problematic for several reasons. First, treating a legal command as a rule that requires an evaluative, and therefore uncertain, factual judgment (such as a judgment about credibility) shears the definition of a "rule" from what is thought to be the key property of rules: that they can be administered in a mechanical fashion thereby producing predictable results. Cf. Neil MacCormick, Institutional Normative Order: A Conception of Law, 82 Cornell L. Rev. 1051, 1051-53 (1997) (commenting that often one can say with greater certainty what ought to be than what is). Second, some legal concepts, such as trade usage, require judgments that cannot strictly be classified as either factual or moral. See generally Ronald Dworkin, Darwin's New Bulldog, 111 Harv. L. Rev. 1718, 1733-35 (1998) (distinguishing anthropological inquiries into the moral beliefs of a group from moral reasoning). The inquiry into trade usage is sociological rather than moral if it is properly done, though the moral values of the decision-maker may creep in. The concept of "foreseeability" does not fit comfortably in either category because while it refers to states of the world (the states of probability of outcome and the mental capacity of the actor), its extreme vagueness makes it a natural vessel for moral judgment. Relatedly, views of the morality of the situation can influence factual judgments, making moral and factual judgments difficult to separate in practice.

The law is sensitive to the difficulty of compartmentalizing evaluative and factual judgments. In areas of the law where the jury is given no say on normative issues, there is a tendency to constrain the jury's power to decide factual issues. Fraud is a good example. Once the law accepts the concept of promissory fraud (i.e., the concept that making a promise with the intention to break it is fraudulent) then there is a possibility of a fraud claim in every suit for breach of contract, creating the risk that juries will find fraud in order to punish breach. The law responds by prohibiting the inference of fraud from the mere fact of breach or by requiring proof of fraud by clear and convincing evidence. See infra note 258 and accompanying text. 
scale because if you want a normative judgment ${ }^{2}$ to be made in the formulation of a common law rule it must be made by a judge. Conversely, fact-specific normative judgments made at the point of application of a standard will be made by the jury as an incident to fact finding. Most literature on the reasons for choosing standards or rules might lead one to think that these values are all that go on the scale because that literature pays virtually no attention to the judgejury issue. ${ }^{3}$ The implication is that while the choice between a rule or standard determines whether judge or jury decides a normative issue, this is a consequence of the choice and not a reason for choosing.

It is clear that other values must go on the scale if we are to give a proper account of the common law. It is common place in negligence law that the values of popular judgment factor significantly in the

2. The terms "normative judgment," "moral judgment," and "value judgment" generally are used interchangeably without regard to the subtle differences between them. Occasionally I do distinguish among these terms. These terms are used to denote judgments made on grounds of policy as well as judgments made on grounds of fairness. This is done mostly for convenience. Classifying policy judgment as a species of moral judgment does have the welcome side-effect of implying that policy judgment involves a moral choice. Some proponents of policy analysis would deny the moral element in policy analysis. In a recent exchange, Ronald Dworkin upbraids Judge Richard Posner for taking the view that judgments on pragmatic grounds are any less moral than judgments on other ethical grounds. See Dworkin, supra note 1, at 1718-19; Richard A. Posner, The Problematics of Moral and Legal Theory, 111 Harv. L. Rev. 1638, 1638-42 (1998) [hereinafter Posner, Problematics]; Posner, Reply, supra note 1 , at $1802-04$.

3. Analyses of the values of rules versus standards that give little or no consideration to the judge-jury issue include: Mark Kelman, A Guide to Critical Legal Studies 15-63 (1987); Richard A. Posner, The Problems of Jurisprudence 42-61 (1990) [hereinafter Posner, Problemis of Jurisprudence]; Louis Kaplow, Rules Versus Standards: An Economic Analysis, 42 Duke L.J. 557, $557-629$ (1992); Duncan Kennedy, Form and Substance in Private Law Adjudication, 89 Harv. L. Rev. 1685, 1685-1778 (1976). Understandably, in many instances the authors neglect the judgejury issue because they do not focus on the common law (Kennedy's article is the sole exception). See Kennedy, supra, at 1685-1778. Kaplow includes among the factors relevant to choosing between a rule and a standard considerations of which institution best resolves an issue. He says little about the judge-jury issue because he focuses on judges, legislatures, and specialized bodies as the relevant institutions. See Kaplow, supra, at 567, 608-611. Kaplow's approach, however, is quite different from that of this Article. He distinguishes between rules and standards by "the extent to which efforts to give content to the law are undertaken before or after individuals act." See id. at 560 (emphasis omitted). He argues that it is an error to assume rules must be simple while standards must be complex. See id. at 586-96. I take complexity to refer to the amount of information that must be considered in determining the law's command in a given situation and the difficulty of processing that information. Kaplow makes the point that rules need not be less complex than standards by reasoning that every complex standard can be reformulated as a "rule equivalent." Id. at 586. This seems true to me only if we exclude the possibility of a standard that allows the decision-maker to choose among different normative perspectives or different weightings of values within a single normative perspective each time the standard is applied. Unlike me, Kaplow puts little stock in the element of normative discretion in standards. 
choice to evaluate conduct under a standard that the jury administers. ${ }^{4}$ By the values of popular judgment I mean the values we place on having small groups of citizens, who are called together for a single case, decide a normative issue after collective deliberation. These values best explain some features of negligence law, the most striking of these features being the rule that the jury decides the reasonableness of conduct even when no fact is in doubt. ${ }^{5}$ Conversely, in contract law there are frequent appeals to the values of professional judgment: by these I mean the values we place on having normative determinations made by people with legal training and the perspective of judges. ${ }^{6}$ Accordingly, judges make some non-rule-bound decisions in contract law, even to the point of assuming the role of fact-finder. These values also help to explain the persistence of rules in contract law, much as the values of popular judgment help to explain the persistence of standards in negligence.

This began as an Article on the role of judge and jury in administering a body of standards lying in the border area between contract, tort, and restitution that require fair dealing in the marketplace. The question I sought to answer was what was the role of the jury in defining inappropriate conduct under these standards. I discovered that to answer this question I had to attempt to untangle the jury's role in identifying blameworthy conduct in negligence law, and to establish that the jury played no similar role in contract law. I also discovered that the concept of unjust enrichment in the law of restitution had properties similar to the concept of improper interference in the law of torts, a subject about which I have written in the past. ${ }^{7}$ My topic grew to encompass the role of the jury in making normative judgments across much of the common law ${ }^{8}$ and even

4. See infra part II.A.; see also infra part III (discussing the role of the judge and jury in contract law).

5. See infra note 121 and accompanying text.

6. See infra notes 33-35 and accompanying text.

7. See Mark P. Gergen, Tortious Interference: How It Is Engulfing Commercial Law, Why This Is Not Entirely Bad, and a Prudential Response, 38 Ariz. L. Rev. 1175 (1996) [hereinafter Gergen, Tortious Interference].

8. One part of the common law I do not cover is the law of property, though I suspect the law of nuisance would be a fertile area to investigate. Nuisance has a negligence-like standard, and nominally the jury decides what is reasonable. However, if my thesis is correct that the jury plays a small role in resolving normative issues when economic interests are at stake, then the jury should play a smaller role in nuisance than it does in negligence. I suspect that a study will show that the jury does play a limited role because equitable relief is usually sought in a nuisance suit. See Richard A. Epstein, A Clear View of the Cathedral: The Dominance of Property Rules, 106 Yale L.J. 2091, 2102 (1997). There is a deeper issue here that is not explored regarding the distinction between economic and property interests. Looking at negligence law, we would say that the jury decides normative issues regarding the reasonableness of conduct that foreseeably harms property interests but not economic interests. Many economic interests, however, can be described as property interests. Indeed, the trope of property is often invoked to describe interests in a job or in insurance benefits when the speaker wants to afford that interest greater legal 
beyond. 9

It may seem quixotic to try to give a principled account of the role of the jury in the American common law. The large role the jury plays in the American common law may best be explained as a natural phenomenon that grew out of planting the English common law in the very different social and political soil of this country. Much of the value in accounting for the role of the jury lies in giving order to what may now seem entirely arbitrary. The analysis provides justification for a rule, proposed in negligence law, that would permit a judge to take the issues of breach and legal cause from a jury only if he can express his decision in the form of a rule..$^{0}$ This rule is best explained as a product of the balance we strike in negligence between the value of popular judgment and the value of having rules. If blameworthy conduct cannot be defined by a rule, then the balance swings decisively in favor of popular judgment. My analysis also shows that the field in which this rule applies is limited. Outside of negligence law little or even negative value is placed on popular judgment. Positive value is placed on professional judgment that is independent of the value of having rules." We shall see that in contract law the value placed on professional judgment is so great that the judge

protection. I also do not discuss the jury's role in calculating damages, though moral considerations play a role here too, most prominently in the calculation of punitive damages.

9. I do not discuss equitable doctrines like unconscionability and estoppel, though they are vital supplements to the common law, because judges have retained the administration of these doctrines. This can be attributed to historical accident, though it is tempting to claim something fundamental in the commitment of equity power to the judge. Equity confers a power to override normal rules of law under broad standards of justice. It makes a great deal of sense to confine such awesome power to judges, because judges appreciate better than juries the gravity of overriding rules.

My approach can be used to buttress Phillip Areeda's argument that the jury ought to play a minor rule in deciding policy issues under the rule of reason strand of antitrust law, See Phillip E. Areeda \& Herbert Hovenkamp, Antitrust Law: An Analysis of Antitrust Principles and Their Application I 321 (1995). My general claim, that the jury plays a small role in evaluating conduct affecting only economic interests, supports Areeda. So, too, does common law doctrine. The rule of reason is grounded in the common law doctrine of restraint of trade. This doctrine is a part of the more general contract doctrine refusing to enforce contracts that violate public policy. Whether a contract violates public policy is a question for the judge. See infra notes 182-84 and accompanying text. I would be careful in extending the analysis too far beyond the common law. It is the nature of the common law that the interests on the defendant's side are primarily economic and private. A common law court cannot directly deprive people of life, liberty, or property. Nor can a common law court override the legislature. It is striking that the jury plays the largest role in deciding normative issues in tort law where interests in physical security are on one side and economic interests are on the other. Very different considerations may come to the fore if the public interest or the defendant's physical security or liberty is at stake.

10. See infra notes $114-15$ and accompanying text.

11. See infra parts III and IV. 
sometimes decides factual issues in making non-rule-based decisions. ${ }^{12}$

The study of the division of normative power between judge and jury in the law reveals areas in which power is contested. The most important of these contested areas is the concept of duty in negligence. Judges have reacted to a perceived liability explosion in negligence by using their power to define duty to rein in the jury. ${ }^{13}$ Another less noted contested area is the concept of abuse of a confidential relationship. The historic power of the jury in this area has become contested as pressure has been applied to expand the scope of the concept to cover ordinary business transactions. ${ }^{14}$ The standards of fair dealing - by these I mean the standard of good faith and fair dealing in contract and related standards in the law of duress and non-disclosure - are yet another contested area. ${ }^{\text {s }}$ So too is the standard of impropriety in the law of tortious interference. ${ }^{16}$ If juries were to play the same role in defining what conduct constitutes fair dealing, improper interference, or unjust enrichment that they historically they have played in defining what is inappropriate conduct in negligence the consequences would be profound. The power to define the legal morality of the marketplace would thereby be shifted from the judge to the jury.

A study of how power is allocated between judge and jury also tells us a great deal about the structure and substance of particular bodies of law. I challenge the view of the Restatement (Second) of Contracts that good faith cannot be reduced to rules and that it must be defined case by case. ${ }^{17}$ While the soul of the concept of good faith may lie in a standard of fair dealing, its corporeal body consists largely (but not entirely) of rules. It is through these rules that judges control the determination of fair dealing in specific circumstances. ${ }^{18}$ I also challenge the view of the Restatement (Second) of Torts that the concept of impropriety in the law of interference is like the concept of reasonableness in negligence. ${ }^{19}$ I argue that the concept of impropriety is more like the concept of unjust enrichment in the law of restitution. ${ }^{20}$ Both are non-categorical concepts defining inappropriate conduct and obligations in the economic arena that supplement bodies of law in which obligations otherwise are defined in categorical terms. ${ }^{21}$ Once the concepts are understood in this way it becomes clear that judges should define them in the first instance,

12. See infra notes $178-85$ and accompanying text.

13. See infra part II.

14. See infra part III.

15. See infra part III.B.

16. See infra part IV.A.

17. See Restatement (Second) of Contracts $\S 205 \mathrm{cmt}$. a (1981).

18. See infra part III.B.

19. See Restatement (Second) of Torts $\S 767 \mathrm{cmt}$. b (1979).

20. See infra part IV.

21. See infra part IV. 
even in cases where there is no established rule. Finally, this Article challenges the traditional view that the concept of abuse of a confidential relationship is an aspect of the law of fiduciary obligation. ${ }^{22}$ It argues that these concepts are best kept separate and that abuse of a confidential relationship should cover only the exploitation of trust for personal gain. Unlike breach of fiduciary duty, it should not cover mere neglect of the interests of another.

The study of the allocation of power between judge and jury also provides a glimpse of the deep chasm in the common law between the economic and personal sphere. Lately there has been a tendency among scholars to conflate these two spheres, and, in particular, to argue that non-physical economic interests ought to be afforded the same protection from injury as physical personal interests because of the importance of the former in the modern world. ${ }^{3}$ If economic interests are to be afforded precisely the same protection as physical interests, then we would give the jury the power to decide on a case by case basis what is inappropriate, harmful conduct in the economic arena. I am confident that few would want to give the jury that power, although many would at the same time defend the historic role of the jury as moral arbiter in the personal sphere, as well as defend the growing use of standards to define obligation in the economic sphere. What this suggests to me is that we tend to look at moral issues in these two spheres in fundamentally different ways. While we are willing to let ordinary intuitive morality define obligation in the personal sphere, a different, more instrumental morality reigns in the economic sphere.

Finally, this study provides a glimpse of the common law's deep ambivalence toward selfishness. ${ }^{24}$ Contract law embraces selfishness ${ }^{25}$

22. See infra part $\mathrm{V}$.

23. See Jay M. Feinman, Economic Negligence: Liability of Professionals and Businesses to Third Parties for Economic Loss $\$ 7.1$ (1995). Feinman advocates a "relational approach" that is very fact sensitive to determining liability for purely economic loss from negligence. See id. § 7.1, at 178 \& § 7.4, at 199-200. He never addresses in this 700-page book whether judge or jury will decide the relational issue. Feinman has good company. Robert $L$. Rabin provides an excellent analysis of the problem of economic loss in negligence that also ignores the issue of judge-jury. See Robert L. Rabin, Tort Recovery For Negligently Inflicted Economic Loss: A Reassessment, 37 Stan. L. Rev. 1513, 1513-38 (1985). Rabin organizes the law around a standard of "proportionality between act and responsibility" but does not address whether judge or jury would administer the standard. Id. at 1534.

24. That the common law harbors such ambivalent views on how people should behave is not surprising. The Crits called these sorts of things antinomies and celebrated them because they created the possibility that in the right hands the common law could be a tool for social reform. Roberto M. Unger's Knowledge \& Politics (1975), is perhaps the classic statement of this view. See id. at 76-100. Oddly, as far as I know the Crits never addressed the question of whether judge or jury had the power to define what precisely was inappropriate behavior in the marketplace.

25. For an unusually candid statement of this view, see C.R Bard, Inc. v. Wordtronics Corp., 561 A.2d 694 (N.J. Super. Ct. Law Div. 1989). The Bard court 
while tort law and the law of restitution demand that people respect the interests of others when their actions might cause injury, and that they not seek to profit from the mistakes or weaknesses of others. ${ }^{26}$ The narrow protection afforded economic interests in tort law signals the law's greater tolerance for selfishness when the interests affected are purely economic. ${ }^{27}$ One overlooked area in the law where the clash between these two attitudes toward selfishness is mediated is in the law on confidential relationships..$^{28}$ While a person is free to take advantage of strangers in commercial dealings (so long as he does not lie and respects a few other categorical rules of conduct), he may not take advantage of a confidant by exploiting his trust. Historically, the jury decides who are confidants. Thus, while the judge defines the legal morality of the marketplace, historically the jury has decided what relations rise above that morality.

I proceed on three assumptions. First, that we use different forms of reasoning to resolve different types of normative issues in the law. Philip Bobbitt's typology of the forms of legal argument is helpful in this regard..$^{29}$ Four of Bobbitt's six modalities of constitutional

stated:

We live, after all, in a society consumed by the desire to acquire wealth, enamored by entrepreneurship and enthralled by success. Competition is always the premise, winning always the goal. In such an environment, can one conclude that the means used by defendant in this case to compete with plaintiff were wrongful? I think not. Plaintiff's remedy is in the market place, not in the courts.

$I d$. at 698 . The decision rejects various tort claims brought against a firm for sending a letter with true harmful statements regarding a competitor to that firm's customers. See id.

26. Gregory $\mathrm{C}$. Keating makes this point nicely by contrasting the reasonableness standard of negligence with a rationality standard. See Gregory C. Keating, Reasonableness and Rationality in Negligence Theory, 48 Stan. L. Rev. 311, 311-12 (1996) ("When we act rationally, we pursue our self-interest in an instrumentally intelligent way. When we act reasonably, we restrain our pursuit of self-interest by acting in accordance with principles that fix fair terms of cooperation."); see also Meinhard v. Salmon, 164 N.E. 545, 548 (N.Y. 1928) (Cardozo, J.) ("A constructive trust is, then, the remedial device through which preference of self is made subordinate to loyalty to others.").

27. The economic-loss rule in negligence is the most obvious feature of the common law that has the effect of holding people to a lower standard of conduct when their actions affect only economic interests. There are many complementary features. For example, the concept of fiduciary relationship with its high standard of conduct implies that a lower standard of conduct applies outside fiduciary relationships, which generally exist only by undertaking.

28. See infra part $\mathrm{V}$.

29. See Philip Bobbitt, Constitutional Interpretation 11-22 (1991) (positing a theory of modalities in constitutional interpretation); see also Dennis Patterson, Conscience and the Constitution, 93 Colum. L. Rev. 270, 270-307 (1993) [hereinafter Patterson, Conscience] (reviewing Constitutional Interpretation and showing how Bobbitt's theory may be relevant to other areas of law); Dennis Patterson, The Pseudo-Debate over Default Rules in Contract Law, 3 S. Cal. Interdisc. L.J. 235, 23587 (1993) [hereinafter Patterson, Pseudo-Debate] (distinguishing "internal-to-law" arguments from "external-to-law" arguments). 
argument have significant analogs in the common law: doctrinal, textual, prudential, and ethical reasoning..$^{30}$ I set doctrinal and textual reasoning aside because, while these forms of reasoning resolve normative issues, they do not involve a value judgment at the point of application. In the terminology of Atiyah and Summers, textual and doctrinal reasons are formal and non-substantive. ${ }^{3}$

My second assumption is that legal education, experience, and the perspective of a judge make a judge better at some, but not all, forms of moral reasoning (they also make a judge better at doctrinal and textual reasoning). Following Fred Schauer and Virginia Wise, we might say these are forms of legal reasoning, though they also involve a value judgment. ${ }^{32}$ Professional training of a non-legal nature (such as training in economics and statistics) is useful but not essential for prudential reasoning. Professional training can be essential if an issue is complex. Training as a lawyer and experience in administering the

30. I put historical reasoning and structural reasoning to the side because their common law analogs are not clear. Bobbitt's typologies are framed with constitutional law in mind. According to Bobbitt, structural argument under the Constitution entails "inferring rules from the relationships that the Constitution mandates among the structures it sets up." See Bobbitt, supra note 29, at 12-13. The "structures" in the Constitution are institutional organisms- the states, the federal government, and the branches of the federal government-that the Constitution creates or that it assumes exist. See id. at 15-16. Common law structural reasoning might be concerned with the relation of different bodies of doctrine in the common law. Or perhaps the relevant structures are the institutions that administer the common law and not the doctrines within the common law. If structures are thought of as the latter, then my argument would be a structural one: we may imply from the assignation to the jury of the issue of breach in negligence that the perspective of ordinary intuitive morality is appropriate to resolving issues of breach. Historical reasoning in the common law might be concerned with the history of the common law, though perhaps not its doctrinal history. An example of a non-doctrinal historical argument is that the law should be changed to conform with actual practice.

31. See Atiyah \& Summers, supra note 1, at 5-8.

32. See Frederick Schauer \& Virginia J. Wise, Legal Positivism as Legal Information, 82 Cornell L. Rev. 1080, 1092 (1997). Schauer and Wise propose a way to differentiate legal and moral reasoning. They argue that whether there is a difference is finally an empirical question of a sociological nature, and that if there is a difference between legal reasoning and moral reasoning it lies in the fact that the information, education, and acculturation of lawyers cause them to reach different outcomes than non-lawyers (or, perhaps, to give different justifications for the same outcome). See id. To expand a bit, Schauer and Wise say that whether law or morality are separate depends on the empirical claim that legal decision-makers decide questions differently than they otherwise would for one of three categories of reasons. See id. at 1099-1108. First, a legal decision-maker may believe the law constrains the domain of reasons for a decision to a set of reasons that is not coterminous with all moral reasons. See id. at 1102 . They call this informational differentiation. See id. Second, the law may influence how a legal decision-maker evaluates relevant reasons. This they call methodological differentiation. See id. at 1100. Third, legal processes or legal culture may alter how a decision is made. This they call procedural and cultural differentiation. See id. at 1100-01; see also Stewart J. Schwab, Limited-Domain Positivism as an Empirical Proposition, 82 Cornell L. Rev. 1111, 1111-22 (1997) (discussing the breakdown of the boundaries between law and morality, which is leading to increased moral reasoning in legal reasoning). 
law makes judges better at prudential reasoning, and their institutional position makes them more inclined to want to resolve issues in a prudent way. Bobbitt defines ethical reasoning in such a way that it is honed by legal training and perhaps best done with philosophical training. ${ }^{33}$ If we instead define ethical argument as an appeal to the ethos of the community, ${ }^{34}$ as some have, and if we want the answer of ordinary intuitive morality, ${ }^{35}$ as sometimes we do, then legal training is not necessary and may even be a hindrance. On the other hand, legal training and the perspective of judges are highly conducive, and may even be essential to ethical analysis of a more systematic sort.

My third assumption is that the form of reasoning that we think ought to be brought to bear in resolving a normative issue should influence to which decision-maker an issue is allocated. In the area of factual inquiry, some issues are committed to judges because we think their legal training and experience are useful to the inquiry. The judge decides whether there was a reasonable basis for bringing a lawsuit in the area of abuse of process, ${ }^{36}$ and the judge decides some factual issues in a legal malpractice case because they require legal analysis. ${ }^{37}$ The United States Supreme Court recently held that the interpretation of a patent was an issue for the judge because patent construction "is a special occupation, requiring, like all others, special training and practice." 38 A rule that judges interpret written agreements has been justified on similar grounds ${ }^{39}$ In the rules that require expert testimony, we can also see an effort to assign issues to

33. See Bobbitt, supra note 29, at 20-21 (defining ethical argument in constitutional law as deriving rules from moral commitments that are reflected in the Constitution itself, in particular the concept of enumerated (and so limited) governmental powers).

34. See J.M. Balkin \& Sanford Levinson, Constitutional Grammar, 72 Tex. L. Rev. 1771,1785 (1994) (describing the ethos-based argument, which rests on "the idea of an 'ethos' that exemplifies the deep structural norms of a given culture").

35. See Robert P. Burns, The History and Theory of the American Jury, 83 Cal. L. Rev. 1477, 1488 (1995) (reviewing Jeffrey Abramson, We, the Jury: The Jury System and the Ideal of Democracy (1994)) (using the term "ordinary intuitive morality").

36. See Restatement (Second) of Torts $\S 673(1)$ (1977).

37. See Sturgis v. Skokos, 977 S.W.2d 217, 221-22 (Ark. 1998) (stating that the probable success of an appeal is a question of law to be determined by a judge and not a jury); Environmental Control Sys., Inc. v. Long, 703 N.E.2d 1001, 1008 (Ill. App. Ct. 1998) (determining that whether an appeal would have been successful involves legal analysis); Steeves v. Bernstein, Shur, Sawyer \& Nelson, P.C., 718 A.2d 186, 190 (Me. 1998) (stating that it is inappropriate for a jury to decide speculative causation issues in a legal malpractice case); Baker v. Fabian, Thielen \& Thielen, 578 N.W.2d 446, 45152 (Neb. 1998) (finding that the judge will determine the state of the law when that is relevant, even to the point of determining that a legal issue was sufficiently unsettled so that it could not be unreasonable for an attorney to fail to pursue it).

38. Markman v. Westview Instruments, Inc., 517 U.S. 370, $388-89$ (1996) (quotation omitted).

39. See Antilles S.S. Co. v. Members of Am. Hull Ins. Syndicate, 733 F.2d 195, 206-07 (2d Cir. 1984). 
people with the appropriate expertise to establish facts that are beyond the ken of both judge and jury. A qualified expert is necessary to establish a fact through scientific method ${ }^{*}$ and the standard of conduct for a professional must be established by the testimony of a person in that field."1 Assuming there is a similar correspondence on normative issues, that an issue is put to the jury indicates that we want (or at least are satisfied with) the answer of ordinary intuitive morality. That an issue is put to the judge indicates that we want an answer based on policy or principle. ${ }^{2}$ That normative decisions are made case by case should not dictate that they be made by the jury for sometimes we want even ad hoc decisions to be based on policy or principle.

\section{THE HISTORIC ROLE OF THE COMMON LAW JURY}

The federal and many state constitutional provisions that protect the role of the common law jury tell us to look to tradition to define the minimum role of the jury. These provisions command that we preserve the power the jury had at some earlier time, typically the date of the provisions' enactment. ${ }^{43}$ This command cannot be obeyed.44 Juries cannot have the power they had in the eighteenth

40. See Daubert v. Merrell Dow Pharm. Inc., 509 U.S. 579, 589-90 (1993). There is a raging debate about whether complex issues of science or economics ought to be taken from the jury entirely. For a balanced review of what little is known on the issue of jury competence in this regard, see Joseph Sanders, Scientifically Complex Cases, Trial By Jury, and the Erosion of Adversarial Processes, 48 DePaul L Rev. 355 (1998).

41. See Melville v. Southward, 791 P.2d 383, 389 (Colo. 1990) (holding that testimony of an orthopedic surgeon does not suffice in suit against podiatrist for malpractice in foot surgery).

42. In addition to facility, there is another reason for assigning policy issues to judges. Policy analysis assumes an instrumental conception of the law that usually measures the value of a decision by its effect on future behavior (I say usually because there can be instrumental value in the immediate effects of decisions in shifting wealth or terminating a dispute cheaply). If a decision is to regulate future behavior, then it must be rendered in a form that is likely to guide people-something that judges can do much better than juries.

43. The Seventh Amendment of the United States Constitution has been read as protecting only the jury's power as fact-finder. See e.g., Colgrove v. Battin, 413 U.S. 149,157 (1973) (stating that fact-finding is the essential function of the jury in civil cases). As a matter of interpretation, this is dubious. The first clause says "the right of trial by jury shall be preserved" without qualification; the second clause prohibits re-examination of facts other than in the manner of the common law. Id. at 150 n.2. As a matter of logic, it is essential, otherwise the Seventh Amendment would freeze the substantive common law as it existed in 1787. Fleming James, Jr. reports that all but two state constitutions preserve the right to a jury trial. See Fleming James, Jr., Right to a Jury Trial in Civil Actions, 72 Yale L.J. 655, 655 n.2 (1963) [hereinafter James, Right to a Jury Trial]. For evidence on the depth of the atlachment to the civil jury in the late eighteenth century, see Charles W. Wolfram. The Constitutional History of the Seventh Amendment, 57 Minn. L. Rev. 639, 653-56 (1973).

44. Fleming James, Jr. gives a devastating critique of the historical test for the right to a jury trial that pays particular focus to the law-equity distinction. See James, 
century for the law was very different in its procedure, substance, institutions, and, it seems, even in its ideology. In the eighteenth century, legal rules were scant but trial judges had a great deal of informal power over the jury. The trial judge could comment on the facts, ask a jury to explain a verdict, argue with the jury, admonish a jury that erred, and order a jury to re-deliberate. ${ }^{45}$ This informal power over juries disappeared in the early years of the nineteenth century and was replaced by substantive and procedural laws that hemmed in both judge and jury. ${ }^{46}$ Around the same time the power to decide the law was taken away from the jury. In the eighteenth century, juries were told that they had the right to "determine the law as well as the fact in controversy" in both civil and criminal cases. ${ }^{47}$ This practice ceased around the early years of the nineteenth century. ${ }^{48}$

Right to a Jury Trial, supra note 43, at 657-64. One point he makes is that doctrines have passed from equity to law and vice versa. See id. at 658-60. He adds that "[a]t no time in history was the line dividing equity from law altogether-or even largely-the product of a rational choice between issues which were better suited to court or to jury trial." Id. at 661 . Law and equity differed in other respects, including not just the obvious difference in remedies, but also procedure (parties could be compelled to testify in equity while evidence was presented orally before a trier of fact in law), and, on occasion, politics. See id. at 661-62.

45. See John H. Langbein, Historical Foundations of the Law of Evidence: A View From the Ryder Sources, 96 Colum. L. Rev. 1168, 1190-93 (1996). Renee B. Lettow describes the shift in the first half of the nineteenth century from a practice of judges informally questioning jurors to decide whether a new trial was in order to the more formal device of a special verdict or judges ordering a new trial based upon their own views without inquiring into the jury's reasoning. See Renee B. Lettow, New Trial for Verdict Against Law: Judge-Jury Relations in Early Nineteenth-Century America, 71 Notre Dame L. Rev. 505, 526-47 (1996).

46. The changes were not just procedural. See A.W. Brian Simpson, The Elusive Truth About Holmes, 95 Mich. L. Rev. 2027, 2036-37 (1997) [hereinafter Simpson, Elusive Truth] (observing that the common law in the nineteenth century was "expanding at the expense of jury discretion").

47. This famous instruction to the jury is from Georgia v. Brailsford, 3 U.S. 1,4 (1794). William E. Nelson concludes that the jury's "power to find law was virtually unlimited" in Massachusetts in the pre-revolutionary period. William E. Nelson, Americanization of the Common Law: The Impact of Legal Change on Massachusetts Society, 1760-1830, 28 (1975). Edith Guild Henderson argues that questions of law probably were not routinely put to the jury in civil cases in most states at the end of the eighteenth century. See Edith Guild Henderson, The Background of the Seventh Amendment, 80 Harv. L. Rev. 289, 299-320 (1966) [hereinafter Henderson, Background]. She bases this conclusion upon the existence of procedural devices that would have enabled judges to take legal questions from the jury. She finds Massachusetts to be an exception (along with Virginia). See id. at 318-19.

48. Nelson dates the removal from the jury of the power to decide the law to around 1805 to 1810 . He attributes this to procedural changes, one being a shift from conducting trials before a panel of three judges (who could give conflicting instructions) to conducting trials before a single judge, and another being more frequent grants of a motion for new trial on the ground a verdict was contrary to the law. See Nelson, supra note 47, at 165-71; see also Kermit L. Hall, The Magic Mirror: Law in American History 107-08 (1989) (touching on parallel developments in other states); Mark S. Brodin, Accuracy, Efficiency, and Accountability in the Litigation 
A variety of factors have been said to lie behind these changes, including a breakdown in what had been a common ethos, a desire for greater legal certainty, and the rise of a less moralistic view regarding commerce. $^{49}$ The development I think most closely associated with the decline in the role of the jury was the growing professionalization of the law in the United States.50 In the early colonial era, only a small percentage of judges had any legal education, ${ }^{\text {s1 }}$ litigation was usually handled without lawyers, ${ }^{52}$ legal training was haphazard, and legal literature was scant (even late in the colonial era a law library would consist of classic English treatises and yearbooks).. The number of lawyers and their role in litigation grew during the 1700 s, it has been said, in response to a dramatic increase in commercial litigation, which spurred demand for lawyers. ${ }^{54}$

The most thorough study of the legal profession in the colonial period is by William Nelson of Massachusetts.ss According to Nelson, in the 1700s, Massachusetts' lawyers and courts began to draw significantly on the common law. This infusion of law seems not to have reduced the role of the jury in the 1700 s. Nelson finds that in Massachusetts the effect was mostly procedural; pleadings came to follow common law forms. Juries, however, retained the ultimate power to decide the great majority of cases that were not resolved on the pleadings. ${ }^{56}$ The growth of the legal profession bore tangible institutional fruit in the immediate post-revolutionary period, roughly from 1780 to 1820 , when law schools, a legal professorate, and an

Process-The Case for the Fact Verdict, 59 U. Cin. L. Rev. 15, $30-32$ (1990) (providing further details); Lettow, supra note 45, at 526-47 (echoing Nelson's finding on the most critical points focusing on the development of power to grant a new trial in the 19 th century). Lettow argues that the jury had greater discretion on legal issues in the colonies than in England, see id. at 508-15, and that the American view that the jury had the right as well as the power to decide the law crystalized in the period prior to the revolution in reaction to perceived misdeeds of Crown judges. See id. at 517-18.

49. See Nelson, supra note 47, at 165-71.

50. See Comment, The Changing Role of the Jury in the Nineteenth Century, 74 Yale L. J. 170, 180-82 (1964) (making this point quite well).

51. See Peter Charles Hoffer, Law and People in Colonial America 39-41 (rev. ed. 1998). Three of 33 judges who served in Massachusetts from 1692 to 1776 were lawyers. See Comment, Changing Role of the Jury, supra note 50, at 171 n.6.

52. See Hoffer, supra note 51 , at 44 . Some colonies forbade lawyers from pleading; many limited the fees that could be charged. See id. at 45-46.

53. See Lawrence M. Friedman, A History of American Law 102 (2d ed. 1985).

54. See Hoffer, supra note 51, at 79-85, 93-97. He argues that there was also an increase in litigiousness, which he attributes to the clash between traditional mores and those of a burgeoning market. See id. at 83-88; see also Milton M. Klein, The Rise of the New York Bar: The Legal Career of William Livingston (1958), reprinted in Essays in the History of Early American Law 394 (David H. Flaherty ed., 1969) (telling a similar story of the career of a prominent New York lawyer in the colonial era, William Livingston).

55. See Nelson, supra note 47 , at $165-71$.

56. See id. at 69-88. 
indigenous American legal literature were created, ${ }^{57}$ and it became the norm for judges to be lawyers. ${ }^{58}$ It was during this later period that the power to decide the law was taken from the jury and trial procedure became formalized.

There was also a change in legal ideology around the same time. Eighteenth century writers grounded the power of the jury to decide the law on a theory of a natural law to which an ordinary man had access and that was preeminent over book law..$^{59}$ A quite different vision of law as a science was painted by Issac Parker in 1816. Parker was Chief Justice of the Supreme Judicial Court of Massachusetts and

57. See Friedman, supra note 53, at 322-23.

58. See Stephen Botein, "What We Shall Meet Afterwards in Heaven": Judgeship as a Symbol for Modern American Lawyers, in Professions and Professional Ideologies in America 49, 55 (Gerald L. Geison ed., 1983) (making the basic point but telling a more complex story). For lawyers (at least), Botein says, it was always the ideal that a judge be a lawyer. See id. at 49 . Further, their victory in the early 1800 s in professionalizing the judiciary was compromised in the middle years of the century by a popular drive to elect judges and in the early twentieth century by a drive for a power of recall. See id. at 54-55; see also Lettow, supra note 45, at 519-21 (putting special emphasis on changes in the structure of courts, in particular the creation of trial courts, that a single judge administered, and the creation of appellate courts).

59. See Comment, supra note 50 , at $172,178-79$. Judge Arnold describes the theory this way:

What kind of world allowed nonprofessionals to have this much power and authority? It was, I believe, a world in which law was regarded as a concrete, discoverable, and palpable fact. It was something that was discoverable by observation and by the application of moral minds to facts. Law, substantive law, was regarded as something organic and internal, not imposed from the outside by an external sovereign whose job it was to make it. Law, in fact, was not made, in the modern sense, not nearly to the same extent. Law was produced by discovery process, but a discovery process of a common-law character that could be resorted to, not just by judges, but also by lay persons-any moral person could do it. In that kind of world with that kind of concept of law, an untrammeled jury makes a lot of sense.

Morris S. Arnold, The Civil Jury in Historical Perspective, in The American Civil Jury 9, 13 (1987); see also Atiyah \& Summers, supra note 1, at 229-39 (1987) (considering that the American theory of law also adds a belief that the law ought to serve a purpose and that the law should be interpreted to suit its purpose).

Richard J. Ross ably tells a complex tale of the relationship between arguments over the printing of law and the rise of popular texts on the common law with contemporary theological and political debates and the effort by lawyers to establish professional status. He concludes:

Between the ascension of the Tudors and the Civil War the common law moved along a continuum, in the realm of perception, from a guild possession towards a national inheritance.... Changes in the communication and use of the common law weakened its late medieval identification as but the course of the royal courts or a national custom effectively committed to guild custody. For the common law was becoming "commoned" along the two interlinked dimensions of knowledge (who knew, could know, and was supposed to know the reasons, fictions, and judgment of the law?) and of ideology (to whom did the common law "belong"?).

Richard J. Ross, The Commoning of the Common Law, The Renaissance Debate Over Printing English Law, 1520-1640, 146 U. Pa. L. Rev. 323, 450 (1998). 
the first professor to hold a chair of law at Harvard. ${ }^{\infty}$ In a speech he gave at Harvard upon assuming the chair he described law as a "science [that was] worthy of a place in the University [and] worthy to be taught, for it cannot be understood without instruction."61 The metaphor of law as a science has multiple meanings all of which imply that the common man has little or no business in making law. Perhaps Parker had in mind legal science as the exegesis of legal texts. Perhaps he had in mind what Robert Gordon describes as Whig legal science in which lawyers distilled and preserved the customs and norms of the people. ${ }^{6}$ Today we might understand this as law as moral philosophy. Nowadays the metaphor of law as science (when it is not being used ironically) is likely to stand for an instrumental view of law as a tool to further the ends of commerce, human welfare, or some other good. The metaphor may also stand for the view that the proper way to study law is empirically.

The modern science of law-legal realism-has been hard on the view of law as doctrinal exegesis or as moral philosophy. At the same time, the modern scientific outlook has led to an increase in the power of the jury. The connection between the modern scientific outlook and the growth of the power of the jury lies in the shift from rules to standards, a change that legal realists championed. When engaged in law reform, the legal realists argued that the form and language of the law should reflect as best they could the substance of the decisions being made. ${ }^{64}$ Karl Llewellyn's work in commercial law is a famous example. 65 That one fruit borne from the realists' labors is a growth in the power of the jury is ironic, for that was not their goal. Indeed, among the realist numbers are two of the most fervent critics of the civil jury, Jerome Frank ${ }^{66}$ and Leon Green. ${ }^{67}$

The legal landscape continues to change rapidly, so it is dangerous

60. See Albert J. Harno, Legal Education in the United States 35-36 (1953). Parker's opinion in Mills v. Wyman, Mass. (3 Pick.) 207 (1825), suggests this turn away from natural law was not complete. Parker involed "principles of natural justice" in explaining why a promise to pay a debt barred by the statutes of limitations was enforceable without consideration. Id. at 209. But he held that a father's promise to pay for his ill son's emergency care was not binding though this was "a strong example of particular injustice sometimes necessarily resulting from the operation of general rules." Id.

61. Friedman, supra note 53, at 321.

62. See Robert W. Gordon, Legal Thought and Legal Practice in the Age of American Enterprise, 1870-1920, in Professions and Professional Ideologies, supra note 58 , at $70,84-87$.

63. See id.

64. See Brian Leiter, Rethinking Legal Realism: Toward a Naturalized Jurisprudence, 76 Tex. L. Rev. 267, 278-79 (1997).

65. See infra notes $160-61$ and accompanying text.

66. See Skidmore v. Baltimore \& Ohio R.R. Co., 167 F.2d 54, 61 (2d Cir. 1948); Jerome Frank, Courts on Trial: Myth and Reality in American Justice 108-25 (1949). Jury].

67. See Leon Green, Judge and Jury 395-417 (1930) [hereinafter Green, Judge and 
to assume that practices and arguments from even as recently as fifty years ago have the same meaning today. The growth of class actions and mass litigation put particularly great pressure on the jury because of the complexity of issues and the magnification of the effects of a single decision (a concern with the unrepresentativeness of a single jury is allayed by a belief that it takes the accumulated decisions of many juries to affect change). ${ }^{68}$ Other changes include the liberalization of damages, the expansion of rights, the development of the plaintiff's bar, and perhaps a growth in litigiousness and a decline in a common set of values (though complaints about growing litigiousness and declining morality are not unique to this age). ${ }^{69}$ The institution of the jury has itself changed in the last fifty years. Until the 1960s and 1970s the jury pool was selected through a "key man system" that was designed to select "men of recognized intelligence and probity." 70 Today the ideal jury is a cross-section of the community, though the development of the art (some think it a science) of jury selection cuts against this new ideal as well as the old one..$^{n}$ Changes in voting rules and the reduction in the size of the jury in some states may have changed the way the jury deliberates. ${ }^{n}$

But, for all these qualms about the relevance of past practices, we cannot avoid using them as the baseline in defining the role of the jury. They must be the baseline, in part, by default. As Fleming James observed forty years ago:

We lack any scientific way of telling what issues are best suited for jury or for court trial, and there is no general agreement (among judges, among politicians, within the profession, or in the community at large) about the matter or even about the underlying premises that should be assumed in making the evaluation. ${ }^{3}$

While recent studies have begun to cast light on how juries behave, ${ }^{74}$

68. See Developments in the Law-The Civil Jury, 110 Harv. L. Rev. 1408, 14891513 (1997) (summarizing the debate in a manner sympathetic to the jury).

69. The same has been said about the eighteenth century as well as the late nineteenth century.

70. See Jeffrey Abramson, We, The Jury 99 (1994).

71. See id. at 100-01.

72. See id. at $180-81$.

73. James, Right to a Jury Trial, supra note 43, at 691 (footnotes omitted); see also 9 Charles Alan Wright \& Arthur R. Miller, Federal Practice and Procedure $\$ 2302$ (2d ed. 1994) (commenting on the "inevitability" of some historical inquiry given the "essentially insoluble problems" posed because of changes such as the collapse of law and equity and the development of unusual kinds of actions).

74. See Richard Lempert, Civil Juries and Complex Cases: Taking Stock After Twelve Years, in Verdict Assessing the Civil Jury System 181, 234-35 (Robert E. Litan ed., 1993) (summarizing a dozen case studies and concluding that juries did a defensible job in fact-finding in complex cases and that errors were usually attributable to difficulty in understanding instructions or in evaluating conflicting expert testimony); see also Valerie P. Hans, The Jury's Response to Business and Corporate Wrongdoing, 52 Law \& Contemp. Probs. 177, 183-86 (1989) [hereinafter Hans, The Jury's Response] (summarizing the results of studies up to 1989, most 
fundamental questions of value remain. What value do we place on legal certainty? What value do we place on doing what people feel is just in a particular case? How much stock do we place on professional opinion about what is right and wrong? How much do we place on popular opinion? Ultimately, the balance one strikes between judge and jury may depend upon whether one thinks of law as social engineering or as a civil religion. The social engineer wants to limit the jury's role because of its unpredictability (it is no surprise that Holmes wanted to reduce the role of the jury); ${ }^{75}$ the civil priest celebrates the jury's role if he is of truly Protestant disposition.

A virtue of the common law method is that it enables us to proceed without resolving fundamental questions of value by limiting the issues on which conflicts in values are worked out to a manageable set that is fluid over time. A useful way to think of the common law is as a set of institutional mechanisms for resolving private disputes that attempts to be at once stable and mutable: stable, because of the high value placed within the system on tradition and conformity; mutable, because of the ineffable and fluid character of its rules, standards, and principles. ${ }^{76}$ Thus, what we look for from the law is a sense of the space in which the role of the jury is up for grabs today. What we do in that space is a matter of choice.

involving criminal trials). Hans concludes that studies of criminal trials generally gave juries high scores in evaluating evidence but low scores in understanding legal instructions. See id. at 184-85. Many studies echo these findings. See, e.g., Phoebe C. Ellsworth, Are Twelve Heads Better Than One?, 52 Law \& Contemp. Probs. 205, 22324 (1989) (finding that a simulation of juries deliberating in a murder trial based upon filmed trial reveals that juries did a good job of evaluating the facts and a poor job on the law, and also finding that deliberations influenced only one juror's position on the law). One case study of a complex antitrust case found that juries had a good grasp of primary facts but a poor grasp of economic effects. See Hans, The Jury's Response, supra, at 187 (citing A. Austin, Complex Litigation Confronts the Jury System: A Case Study (1984)).

75. See Baltimore \& Ohio R.R. Co. v. Goodman, 275 U.S. 66, 70 (1927) (trying to lay down rules to define the standard of conduct to no ultimate avail); Lorenzo v. Wirth, 49 N.E. 1010, 1011 (Mass. 1898) (Holmes, J.) (same); see also Oliver Wendell Holmes, The Common Law 123-29 (1881) (explaining his views on the jury's role in negligence).

76. See A.W. Brian Simpson, The Common Law and Legal Theory, reprinted in Legal Theory and Legal History 358, 367 (1987) [hereinafter Simpson, The Common Law] (describing the common law as a system of customary law in which the relevant customs are those of a professional elite because "ideas and practices exist only in the sense that they are accepted and acted upon within the legal profession"). In England, this way of thinking about the common law has (or, at least, used to have) conservative implications because there the common law is administered by a professional elite that is (or, at least, used to be) imbued with respect for legal doctrine. 


\section{PHYSICAL OR PERSONAL TORTS}

\section{A. Negligence}

Negligence law is the logical place to start in mapping the role of the jury in deciding normative issues in the common law for it is here that the jury has the most say. A danger in starting with negligence is that you will think it the norm. Do not. It is the exception. At the heart of negligence law is a standard of conduct of the reasonably prudent person. ${ }^{n}$ The jury administers this standard by making a normative determination of what constitutes appropriate conduct in a given situation along with a factual determination as to whether the defendant's conduct met the standard. ${ }^{78}$ The jury has a great deal of

77. One recent study of pattern jury instructions and cases found this standard used everywhere except Louisiana. See Stephen G. Gilles, The Invisible Hand Formula, 80 Va. L. Rev. 1015, 1023 n.21 (1994) [hereinafter Gilles, The Invisible Hand]. The continued and near universal use of the reasonably prudent person standard might be chalked up to inertia. Evidence that there is another factor at work can be found in the fate of a proposal in 1956 in California to modify the pattern jury instruction on negligence to a risk-utility standard. See id. at 1049 (citing 1 California Jury Instructions: Civil No. 101-H, at 236 (4th ed. 1956)). The proposal was dropped after the trial judges of Los Angeles expressed discomfort with the possible usurpation of the role of the jury. See id.

78. See Fleming James, Jr., Functions of Judge and Jury in Negligence Cases, 58 Yale L.J. 667, 676 (1949) [hereinafter James, Functions of Judge] ("On the whole the rules of accident law are so formulated as to give the jury considerable scope in deciding what the parties should have done, in each specific case, as well as what they did do. The cardinal concept is that of a reasonably prudent man under the circumstances...."); see also Brian J. Ostrom et al., A Step Above Anecdote: $A$ Profile of the Civil Jury in the 1990s, 79 Judicature 233, 234-35 (1996) (summarizing the types of civil cases juries actually decide). In the period examined by Ostram a huge percentage of jury trials (approximately 17,000 out of 22,000) were in cases involving automobile accidents, premises liability, and medical malpractice. See id. at 234.

It is often said that the standard of a reasonably prudent person presents a mixed question of law and fact. See Francis H. Bohlen, Mixed Questions of Law and Fact, 72 U. Pa. L. Rev. 111, 112 (1924). Bohlen defines general standards of conduct, and in particular the reasonableness standard of negligence, as "mixed questions of law and fact" because they do not involve finding facts, meaning "something which has happened or existed;" but neither do they involve declaring law, meaning "a body of principles and rules which are capable of being predicated in advance and which are so predicated." Id. at 112. The reasonableness standard of negligence "is more nearly akin to a declaration of law than to a finding of fact, since it does create obligatory standards, which, if created by the jury, are, it is true, binding in only the particular case then before it ...." Id. at 114. Bohlen describes this task as "administrative" and likens it to a ruling by an administrative board. Id. at 115-16; see also James B. Thayer, "Law and Fact" in Jury Trials, 4 Harv. L. Rev. 147, 171-73 (1890) (treating this standard as administrative). This label is misleading. A decision about what is prudent conduct in the circumstances is not law-like in any meaningful respect. Not only does it not produce an authoritative statement about how people ought to treat others (Bohlen's point), but it is not law-like in the sense that making a decision about what is prudent conduct requires the training, knowledge, or perspective of a lawyer or judge. 
normative discretion in deciding what is reasonably prudent conduct.

Most academic scholarship on negligence law passes over this feature of the law, I think, because it makes theorizing about how negligence cases ought to be decided seem academic. ${ }^{7}$ Stephen Gilles identifies some of the normative judgments that must be made in applying the standard..$^{\infty}$ These include judgments about the extent (if any) to which a person may legitimately prefer his interests over those of other people, whether to engage in a cost-benefit analysis, and, if so, what value to assign to injury and avoidance costs. ${ }^{81}$ The jury must decide what weight, if any, to give to custom. It may be swayed by deontological rules or biases of the sort collected and displayed by Leo Katz like so many exotic butterflies (for example, rules distinguishing direct and indirect effects and action and inaction). There is evidence that juries hold corporations to a higher standard of responsibility than individuals. ${ }^{84}$ Juries may in practice apply a principle akin to strict liability in which an injurer is liable unless avoidance is so costly as to be impractical. ${ }^{8}$ Logically, there must be room within the reasonably prudent person standard for every plausible normative theory of negligence law (otherwise it would not be a plausible theory), and there are many such theories. ${ }^{85}$ In practice,

79. See Patrick J. Kelley, Who Decides? Community Safety Conventions at the Heart of Tort Liability, 38 Clev. St. L. Rev. 315, 379-82 (1990) (offering a theory of tort law that puts the jury at the center); Catharine Pierce Wells, Tor Law as Corrective Justice: A Pragmatic Justification for Jury Adjudication, 88 Mich. L Rev. $2348,2386-90$ (1990) (giving an account of negligence law that puts the jury at the center). Kelley's theory is that tort law redresses private injustices by enforcing preexisting norms of conduct. See id. at 319. This will not do as a global theory even of negligence law, where the theory is most accurate. In many negligence cases there is no pre-existing norm, and when there is a clear pre-existing norm in the form of a customary rule of behavior it is not conclusive.

80. See Gilles, The Invisible Hand, supra note 77, at 1029-30.

81. See id.

82. Custom is relevant when deciding what is reasonably prudent conduct but it is not decisive. See T.J. Hooper, 60 F.2d 737, 740 (2d Cir. 1932). The area of professional malpractice is an exception. See infra note 139.

83. See generally Leo Katz, Ill-Gotten Gains: Evasion, Blackmail, Fraud and Kindred Puzzles of the Law 1-264 (1996) (exploring the different features of the basic rules by which people apportion blame for wrongdoing).

84. See Valerie P. Hans, The Contested Role of the Civil Jury in Business Litigation, 79 Judicature 242, 244 (1996) [hereinafter Hans, The Contested Role] (reporting findings of study using mock juries and surveys).

85. See Gilles, The Invisible Hand, supra note 77, at 1021-27; see also Keating, supra note 26, at 324 (offering a spirited defense of this as a principle of reasonableness grounded on the proposition that of the two interests at odds in accident cases - on the plaintiff's side, the interest in personal security and on the defendant's side, the interest in freedom of action-the plaintiff's interest is weightier).

86. See Gary T. Schwartz, Mixed Theories of Tort Law: Affirming Both Deterrence and Corrective Justice, 75 Tex. L. Rev. 1801, 1802-10 (1997) [hereinafter Schwartz, Mixed Theories] (presenting a thoughtful argument for a view of tort law with a focus on accident law that mixes the goal of deterrence (which is historically, but not necessarily, connected to an economic perspective) and the goal of corrective justice 
the normative discretion of the jury goes beyond that permitted by the standard. It is said that juries tend to impose the cost of an injury on whomever can best absorb that cost-on whoever has the deepest pockets-without regard to whether this person was in any way at fault or even whether he caused the injury.7 But it is difficult to claim this as a normative judgment that the jury is entitled to make within negligence law.

Breach is not the only issue put to the jury in negligence that requires a normative judgment. Normative judgment is necessary when the jury decides the harmful consequences from breach for which the breacher may fairly be held liable under the issue of legal cause, an issue generally treated as one for the jury.8s It is necessary when the jury apportions responsibility among parties under a system of comparative fault, for apportionment requires weighting deviations from the standard and other variables. ${ }^{89}$ And a subjective value judgment is necessary when a jury decides what is fair monetary compensation for non-economic injury. A judge may take these issues away from the jury, but only if he believes the answer is not in doubt, or, in the case of damages for personal injury, if the jury's answer seems manifestly unjust or a product of passion or prejudice.90

A striking testament to the role of the jury in negligence law is the

(which is concerned with righting wrongs)).

87. See Hans, The Contested Role, supra note 84, at 243; see generally Jennifer H. Arlen, Should Defendants' Wealth Matter?, 21 J. Legal Stud. 413 (1992) (arguing that it should be relevant on economic grounds).

88. See Cruz-Mendez v. ISU/Ins. Servs. of S. F., 722 A.2d 515, 525 (N.J. 1999) (citation omitted) (treating legal cause as an issue for the jury); Atkinson v. Scheer, 508 S.E.2d 68, 71 (Va. 1998). The judge may play a greater role when the issue is intervening cause. See Lefthand v. City of Okmulgee, 968 P.2d 1224, 1226 (Okla. 1998) (using a spurious rule of intervening cause to dismiss a claim); Restatement (Second) of Torts $\S 453$ (1965) (making proximate cause an issue for the judge insofar as it turns on a determination whether foreseeable intervening conduct absolves an actor from liability). But see McCoy v. American Suzuki Motor Corp., 961 P.2d 952, 957 (Wash. 1998) (putting the issue of intervening cause to the jury under a standard couched in terms of foreseeability).

89. Comparative fault gives the jury greater normative discretion along several dimensions. One new dimension is apportioning responsibility where a party is negligent per se because his actions violate state law. See Bailey v. Black, 394 S.E.2d 58,61 (W. Va. 1990) (asking the jury to allocate responsibility between a patron and a bar where the patron wrecked his car after leaving the bar drunk). In Bailey, the bar violated state law by selling the patron liquor, and the patron violated the law by driving while intoxicated. See id. at 59. The practice in some states of leaving the jury in the dark about the legal consequences of how fault is apportioned is inexplicable under a theory that conceives of the jury as moral arbiter as well as fact-finder. See Dilaveris v. W.T. Rich Co., 673 N.E.2d 562, 565 (Mass. 1996) (holding that instruction is at the discretion of the trial judge but that it is abuse of discretion not to advise the jury of the effects of the verdict where the jury seems to be speculating about the matter).

90. See Berry v. Risdall, 576 N.W.2d 1, 4 (S.D. 1998); Pope v. Moore, 711 S.W.2d 622,624 (Tex. 1986). 
influence the jury has had on the basic structure of negligence law.9 Leon Green, Fleming James, and Robert Keeton tell of times in the history of negligence law when popular values expressed through repeated jury verdicts have changed the position of the law in important regards. ${ }^{2}$ They say that the willingness of juries to reach a compromise verdict in cases of contributory negligence presaged and laid the groundwork for the shift to comparative fault.93 They say that the juries' sympathy for workers injured on the job led to the demise of the unholy trinity of doctrines that barred recovery for on-the-job injuries and the adoption of workers' compensation. ${ }^{*}$ They also say that the inclination of juries to ignore the issue of fault and insist that those with deep pockets compensate the people whom they injure presaged a shift to strict liability (and perhaps even to a system of social insurance if juries care little about causation).9s Perhaps a future generation of legal scholars will look back to this era and say that juries changed the legal relationship between employers and employees by demanding that employers demonstrate good cause for firing an employee whatever the formal legal rights of the employee.\%

Of course, judges are not without power, even in negligence law. Duty is the most significant issue in the prima facie negligence case that the judge decides even if he believes the answer is doubtful." $A$

91. It is important to not overstate the role of the jury in bringing about these changes. Juries could not have done these things by themselves. Juries have to act with the complicity of judges who choose to submit a case to the jury that the judge might well have decided himself under the law on the books. The presence of the jury enables judges who question the morality of the law on the books to validate their moral views by passing the issue to the jury. It also enables judges to undermine laws they find offensive without challenging them directly. And, perhaps, trial judges learn from juries or are influenced by the moral views of juries.

92 See Green, Judge and Jury, supra note 67, at 395-417; Robert E. Keeton, Venturing To Do Justice 74-75 (1968); James, Functions of Judge, supra note 78, at 686-87.

93. See Keeton, supra note 92; see also Frank, supra note 66, at 110-11 (observing the same phenomenon with a more jaundiced eye than Keeton).

94. See Green, Judge and Jury, supra note 67, at 122-23; James, Functions of Judge, supra note 78, at 686-87.

95. See James, Functions of Judge, supra note 78, at 687-90.

96. See Mark P. Gergen, $A$ Grudging Defense of the Role of the Collateral Torts in Wrongful Termination Litigation, 74 Tex. L. Rev. 1693, 1726-37 (1996) [hereinafter Gergen, Grudging Defense] (summarizing studies of outcomes in wrongful termination litigation and examining outcomes in reported Texas cases, and concluding that the Texas cases bear out the perception that employees fare much better with juries than they do with judges).

97. See, e.g., Palka v. Servicemaster Management Servs. Corp., 634 N.E.2d 189, 192 (N.Y. 1994) ("Unlike foreseeability and causation, which are issues generally and more suitably entrusted to fact finder adjudication, the definition of the existence and scope of an alleged tortfeasor's duty is usually a legal, policy-laden declantion reserved for Judges to make prior to submitting anything to fact-finding or jury consideration."). The Restatement does not speak much of duty. Rather, it says that the judge defines the standard of conduct, and, if the conduct required in a given circumstance can be expressed through a rule, then the judge states the rule. See 
judge may dismiss a negligence claim by finding that the defendant was under no duty. ${ }^{98}$ A judge may also limit the factual or normative issues put to the jury by defining duty in limiting terms. ${ }^{99}$ The issue of duty has been relegated to the margins of tort law to a set of "limited duty" or "no duty" rules that apply to claims for purely emotional100 or purely economic injury ${ }^{101}$ and claims where the defendant's negligence lay in failing to control or warn about another person ${ }^{102}$ or in failing to act more generally. ${ }^{103}$ For much of this century, courts pushed out the boundaries of liability under these limited-duty rules, usually by crafting new bright-line rules. ${ }^{104} \mathrm{~A}$ few states adopted standards instead of bright-line rules to define the scope of liability in these

Restatement (Second) of Torts § 285(c) cmt. e (1965).

98. See Kentucky Fried Chicken, Inc. v. Superior Ct., 927 P.2d 1260, 1262 (Cal. 1997).

99. See Baltimore \& Ohio R.R. Co. v. Goodman, 275 U.S. 66, $69-70$ (1927)

(Holmes, J.) (finding that a highway traveler who came to a railroad had a duty only to stop, look, and, if the view of the track was obstructed, get out of his vehicle).

100. See Restatement (Second) of Torts $\$ \S 313 \& 436 A$.

101. See Louisiana ex rel. Guste v. M/V Testbank, 752 F.2d 1019, 1023 (5th Cir. 1985); Local Joint Executive Bd. v. Stern, 651 P.2d 637, 638 (Nev. 1982); Stevenson v. East Ohio Gas Co., 73 N.E.2d 200, 201-03 (Ohio Ct. App. 1946) (discussing many of the leading early cases).

102. See Restatement (Second) of Torts $\$ \$ 315-20$.

103. See id. $\S \S 314,314$ A \& 314B.

104. Consider the law regarding bystander claims for mental anguish experienced in perceiving an accident. A few decades ago, courts began to recognize such claims when the bystander was closely related to the victim and near the accident in time and space. See Dillon v. Legg, 441 P.2d 912, 920-21 (Cal. 1968) (defining the scope of the new duty by vague guidelines of foreseeability and proximity that the court implied judges were to work out in later cases). Later cases tend to define the scope of the duty by bright-line rules, the most common being a rule that requires that the bystander be present at the scene of the accident or arrive immediately thereafter. See, e.g., Krouse v. Graham, 562 P.2d 1022, 1031-32 (Cal. 1977) (ruling that sensory and contemporaneous observance of an accident are not necessary to recover damages for emotional distress as long as observance is almost contemporaneous with the accident); Barnhill v. Davis, 300 N.W.2d 104, 108 (Iowa 1981) (stating that to recover for emotional distress caused by witnessing peril to a victim, the bystander must be located near the scene of the accident); Dziokonski v. Babineau, 380 N.E.2d 1295,1302 (Mass. 1978) (concluding that recovery will be granted where "the parent either witnesses the accident or soon comes on the scene while the child is still there"); Corso v. Merrill, 406 A.2d 300, 306 (N.H. 1979) (requiring a relatively close connection in time and geography between the negligent act and the resulting injury); Portee v. Jaffee, 417 A.2d 521, 527 (N.J. 1980) ("[O]bserving the death or serious injury of another while it occurs is an essential element of a cause of action for the negligent infliction of emotional distress."); Gabaldon v. Jay-Bi Property Management, Inc., 925 P.2d 510, 510 (N.M. 1996) (ruling that to recover there has to be a contemporaneous sensory perception of the accident by the parent of the child); Sinn v. Burd, 404 A.2d 672, 686 (Pa. 1979) (allowing recovery for a mother who witnessed the violent death of her small child); Kinard v. Augusta Sash \& Door Co., 336 S.E.2d 465, 465 (S.C. 1985) (ruling that plaintiff bystander must contemporaneously perceive an accident in order to recover damages for emotional trauma); Gates v. Richardson, 719 P.2d 193, 199 (Wyo. 1986) (stating that in order to recover damages for emotional distress the person must witness the serious accident or its aftermath). 
areas of limited duty. Among these, some turned the application of the standard over to the jury ${ }^{105}$ while others kept it as an issue for the judge..$^{106}$

Looming behind the limited-duty rules is a general duty to take reasonable care in conduct that might foreseeably harm other people or their property.107 The authority for such a general duty is thin, ${ }^{123}$

105. See Tommy's Elbow Room, Inc. v. Kavorkian, 727 P.2d 1038, 1045 (Alaska 1986); State v. Eaton, 710 P.2d 1370, 1378 (Nev. 1985); McAllister v. Ha, 496 S.E.2d 577, 582-83 (N.C. 1998). These cases involve bystander liability.

106. See Masaki v. General Motors Corp., 780 P.2d 566, 576 (Haw. 1989) (involving bystander liability); Bowen v. Lumbermens Mut. Cas. Co., 517 N.W.2d 432, 443 (Wis. 1994) (characterizing the issue of limitation as one of public policy rather than duty).

107. Heaven v. Pender, 11 Q.B.D. 503 (Eng. C.A. 1883), is the original expression of this principle. The author (Lord Esher) added in Le Lievre v. Gould, 1 Q.B. 491 (Eng. C.A. 1893), that this principle held only if the defendant engaged in an affirmative act. Percy $\mathrm{H}$. Winfield explores the history of the concept of duty in negligence. See Percy H. Winfield, Duty in Tortious Negligence, 34 Colum. L. Rev. 41, 51 (1934). Winfield explains that the concept of duty did not appear until the middle of the nineteenth century. See id. It first appeared and then was developed in cases where the defendant was under a duty to someone other than the plaintiff by contract or statute. The question was whether the plaintiff who was injured by misperformance had a cause of action. See id. at 49-53. Let me suggest a different interpretation of the story told by Winfield. In the pre-nineteenth century cases of liability for inadvertent injury (which involved neglect by inn-keepers, common carriers, professionals, people in a common calling, public officials, bailees, and people who controlled dangerous things) there was no need for a concept like that of duty because it was self-evident that persons in the defendant's class were obligated to take care to protect people in their charge or to control the thing in their charge. The concept of duty emerges with claims where it is not so clear whether the defendant should be under a legal obligation to watch out for the plaintiff's interests. Striking evidence of a belief that duties to others were limited is found in what Winfield describes as a seminal case in introducing the concept of duty, Langridge $v$. Levy, 150 Eng. Rep. (Ex. 1837). The plaintiff pled a general duty to use reasonable care in handling dangerous instruments, to which the judges responded: "[W] think this action may be supported without laying down a principle which would lead to that indefinite extent of liability ...." Id. at 530; see also Winfield, supra, at 53-55.

Winfield does not explain why the plaintiff in Langridge pled a duty when the concept was not yet in the law. The answer to this mystery may be found in $M$. Prichard's Scott v. Shephard (1773) and the Emergence of the Tort of Negligence. Prichard argues that the concept of a general duty of care emerged as an artifact of the rules of pleading. See M. Pritchard, Scott v. Shephard (1773) and the Emergence of the Tort of Negligence 30-33 (1976). In cases where the claim was neglect in the performance of an undertaking (Prichard's primary example is claims against common carriers), the plaintiff would plead that the defendant breached an obligation that existed under the custom of the realm and not an obligation in contract in order to avoid the harsh rules of joinder in contract. See id. at 31. Plaintiffs came to plead a general duty rather than a specific custom because their suit would be dismissed if they plead the wrong custom. See id.

108. One of the most famous duty cases of the last generation, Tarasoff $v$. Regents of Univ. of CaL, 551 P.2d 334 (Cal. 1976), which held that a psychiatrist was under a duty to warn a third party of a danger from a patient, found that duty analysis should begin with the "fundamental principle" stated in Heaven v. Pender, 11 Q.B.D. 503 (Eng. C.A. 1883), and that courts should depart from it only upon a careful balancing of concerns of policy and fairness. See Tarasoff, 551 P.2d at 342. The Tarasoff court followed Rowland v. Christian, 443 P.2d 561 (Cal. 1968), which held that "no such 
surprisingly so given its fundamental significance. One consequence of the "bottom-up" nature of the common law is that fundamental principles can be left unsaid because they are rarely put in issue. In a growing number of cases, judges take the evaluation of conduct that would seem to fall within this general duty away from the jury, sometimes by announcing a particularized no-duty rule, ${ }^{109}$ and sometimes by an ad hoc no-duty decision. ${ }^{110}$ These cases are part of the on-going conservative counter-revolution in torts.

Thirty years ago, Judge (then Professor) Robert Keeton observed that "[o]ne of the current riddles of tort law, of pervasive significance, is whether any general principle is emerging concerning this problem of allocating responsibility for evaluative findings as distinguished from findings of physical facts and events."111 In negligence, to solve this riddle we must distinguish issues of duty from issues of breach and legal cause. This is no easy task because duty analysis is said to be a function of the same broad considerations of policy, fairness, and reasonableness that guide breach and legal cause-analysis. ${ }^{12}$

exception [to the general principle of duty] should be made unless clearly supported by public policy." Id. at 564 . In Rowland, however, the court formulated the general duty differently to cover only affirmative acts. See id. at 565-69; see also Stagl v. Delta Airlines, Inc., 52 F.3d 463, 469 (2d Cir. 1995) (arguing that under New York law "the judicial power to modify the general rule [of Heaven $v$. Pender] ... is reserved for very limited situations" (citations omitted)).

109. See William Powers, Jr., Judge and Jury in the Texas Supreme Court, 75 Tex. L. Rev. 1699, 1719 (1997) (observing that the Texas Supreme Court has increased the role of judges and diminished that of the jury by announcing particularized rules of duty (or of no duty)). Powers cites Caterpillar, Inc. v. Shears, 911 S.W.2d 379 (Tex. $1995)$, a products liability case involving a front-end loader with a removable protective cage that the employer detached, leading the plaintiff to be injured. See Powers, supra, at 1704-05. The plaintiff argued that to have a removable cage was a design defect, and the jury agreed. See Shears, 911 S.W.2d at 381. The court reversed by announcing a particularized duty rule: a manufacturer has no duty to design a multipurpose machine in a way that makes it impossible to use one of its intended settings (the cage had to be removed to work between decks). See id. at 384-85. Powers also cites Smithkline Beecham Corp. v. Doe, 903 S.W.2d 347 (Tex. 1995), where the court ruled that a drug tester had no duty to warn about the risk of false positives. See Powers, supra, at 1708. Powers notes that the issue would have gone to the jury had duty been defined broadly as a duty "to refrain from imposing foreseeable, unreasonable risks." Id. at 1708. Powers relates these developments to a debate between Leon Green and Page Keeton. See id. at 1719. Keeton defined duty broadly as a duty to act "reasonably" and relied on the jury to define the scope of the duty by deciding the issues of proximate cause and breach. See id. at 1701 . Green wanted to give trial judges (not appellate) greater authority by moving more questions of scope of liability from proximate cause to duty. See id. at 1701-03; see also Gary T. Schwartz, The Beginning of the Possible End of the Rise of Modern Tort Law, 26 Ga. L. Rev. 601, 659-63 (1992) [hereinafter Schwartz, The Beginning] (describing the onslaught of no-duty decisions).

110. See Stagl, 52 F.3d at 468; Salazar v. South Suburban Metro. Recreation and Park Dist., 614 P.2d 910, 911 (Colo. App. 1980); Kenney Mfg. Co. v. Starkweather \& Shepley, Inc., 643 A.2d 203, 206 (R.I. 1994).

111. Keeton, supra note 92 , at $72-73$.

112. See, e.g., Taco Bell, Inc. v. Lannon, 744 P.2d 43, 46 (Colo. 1987) ("No one 
Indeed, many assume that the law of duty has no useful doctrinal substance. ${ }^{113}$ The solution to the riddle identified by Keeton is important in negligence law. If only the label distinguishes an issue of duty from an issue of breach or legal cause, then no good argument exists within negligence law to confront judges eager to cut back on the jury's role as moral arbiter by recasting issues of breach and legal cause as issues of duty. Putting the same point less dramatically, the solution, if one exists, will define the sorts of normative issues that the jury ought to resolve as a matter of negligence law. A possible solution to this riddle and two justifications for it follow. To solve the riddle, we must separate the power to decide normative issues that the jury enjoys as incident to its role as fact-finder from the power that it enjoys because we believe that it has something useful to say on a normative issue.

The best distinction I know of between duty determinations and breach and legal-cause determinations is a rule requiring that a duty determination take the form of either a general standard or of a

factor is controlling, and the question of whether a duty should be imposed in a particular case is essentially one of fairness under contemporary standards - whether reasonable persons would recognize a duty and agree that it exists."); Hopkins v. Fox \& Lazo Realtors, 625 A.2d 1110, 1116 (N.J. 1993) ("The actual imposition of a duty of care and the formulation of standards defining such a duty derive from considerations of public policy and fairness."). Furthermore, in Palka v. Servicemaster Management Servs. Corp., 634 N.E.2d 189 (N.Y. 1994), the court held that:

[D]uty is not something derived or discerned from an algebraic formula.

Rather, it coalesces from vectored forces including logic, science, weighty competing socioeconomic policies and sometimes contractual assumptions of responsibility. These sources contribute to pinpointing and apportioning of societal risks and to an allocation of burdens of loss and reparation on a fair, prudent basis.

Id. at 192.

On the laundry list of considerations relevant to these issues administrative considerations appear on the duty list but not on the breach and proximate cause list. See D'Ambra v. United States, 338 A.2d 524, 527-28 (R.I. 1975). This follows from an elusive difference between judge and jury. Judicial decisions can have a legal effect beyond the immediate case so judges ought to consider how their decision will influence future behavior by judges and other actors within the legal system. The actions of a jury have no legal effect beyond the immediate case and so do not seem to raise the administrative concerns. The difference is elusive because a jury's decision may affect people's behavior. Indeed a jury counts on this when it tries to "send a message" through a verdict.

113. See W. Page Keeton et al., Prosser and Keeton on the Law of Torts $\$ 53$, at 357-58 (5th ed. 1984). Other scholars of the era when Prosser first wrote, who treated the law more carefully than Prosser, were equally disdainful of the concept of duty. See Buckland, The Duty to Take Care, 51 L.Q. Rev. 637, 639 (1935) (concluding that the concept of duty is "an unnecessary fifth wheel on the coach, incapable of sound analysis and possibly productive of injustice"); see generally Winfield, supra note 107, at 41-66 (reviewing the history and uses of the concept of duty in negligence and concluding that we would be better off without it though it was probably too engrained at that point to eliminate). Winfield and Buckland assume that an action for negligence lies only for conduct causing an injury to person or property. They do not address the question of what concept limits the negligence action other than duty. 
categorical rule that applies beyond the immediate case. ${ }^{114}$ This rule does not require that statements of duty take the form of rules. Duties can be expressed in the form of a standard, the most famous such standard being the duty of reasonable care under the circumstances. Nor is the rule an absolute prohibition on ad hoc noduty determinations by a judge under a standard. A judge could dispose of a claim under a standard without formulating a rule or a more precise standard if he thought there was no factual or normative doubt regarding the answer under the existing standard. The rule can be restated as follows: for a judge to dispose of a negligence claim by finding no duty, he must state a rule or a standard that applies beyond the immediate case and that contains no factual or moral element that is open to doubt.115 The precise degree of doubt at which an issue must go to the jury is a function of the general standard for summary judgment, directed verdict, and judgment notwithstanding the verdict. The federal standard is reasonable doubt. Some states have a lower

114. See David W. Robertson et al., Torts, $186-88$ (2d ed. 1998) (focusing their definition on the need to frame no-duty rules to facilitate summary judgment, Robertson concludes that to serve this purpose, a no-duty rule must take the form of a "rule of law of enough breadth and clarity to permit the trial judge in most cases raising the problem to dismiss the complaint or award summary judgment for the defendant on the basis of the rule"); see also Stagl, 52 F.3d at 469 (Calabresi, J., dissenting) ("where, as here, the applicable duty relationship is well established, we do not believe New York law condones the limitation of a familiar liability rule simply to avoid placing a disproportionate burden on a defendant in a particular case"); Bolieu v. Sisters of Providence, 953 P.2d 1233, 1241 (Alaska 1998) (responding to dissenting argument that hospital should have duty to protect spouses of staff from infectious diseases only in the case of unusual and severe diseases and concluding that "such fact-intensive inquiries pertain to the issues of breach, causation, and damages, not the threshold legal question of whether a duty exists."); Hopkins, 625 A.2d at 1116 ("The analysis is both very fact-specific and principled; it must lead to solutions that properly and fairly resolve the specific case and generate intelligible and sensible rules to govern future conduct."); Peterson v. Spink Elec. Coop., Inc., 578 N.W.2d $589,592-93$ (S.D. 1998) (arguing that it was inappropriate to deny a claim for lack of duty on grounds that risk was not foreseeable because the determination is fact intensive); Nivens v. 7-11 Hoagy's Corner, 943 P.2d 286, 294 (Wash. 1997) (Sanders, J., dissenting) ("The majority confuses the general duty of care with the plaintiff's specific theory of liability.").

115. A no-duty rule would take the form "If $n_{1}, n_{2}, \ldots n_{n}$, then no duty," where $n$ is the presence or absence of a fact that usually can be resolved on the basis of the pleadings. It is a mistake to tie the definition of duty rule exclusively to summary judgment for a duty rule might resolve the issue of breach without disposing of other issues in a negligence claim. Such a rule would take the form "If $n_{1}, n_{2}, \ldots n_{n}$, then breach." See Baltimore \& Ohio R.R. Co. v. Goodman, 275 U.S. 66, 69-70 (1927) (Holmes, J.) (finding that a highway traveler who came to a railroad had a duty to stop, look, and, if the view of the track was obstructed, get out of his vehicle). What a duty rule cannot contain is a standard-like element that asks for an evaluative judgment. Thus, the standard of "reasonably prudent care under the circumstances" cannot properly be described as a duty rule because it contains the element of reasonableness, which requires an evaluative judgment. To be more precise, a duty rule cannot on its face require an evaluative non-factual judgment, and, in particular, it cannot on its face require a normative judgment. 
standard, requiring only a "scintilla" of evidence"16 to establish factual doubt. One problem with the scintilla standard is that it is not an intelligible measure of normative doubt.

Under this rule, while similar normative considerations bear on a judge's analysis of duty and a jury's analysis of breach and legal cause, in duty analysis these considerations bear (or at least ought to bear) on the formulation of a rule or standard, while in breach and legal cause analyses they bear directly on the decision of the case. Put in such naked terms the argument seems unrealistic (judges are likely to have the case at hand foremost in mind in formulating a duty rule) and at odds with the common law method (in which rules are always provisional). But these seem to me quibbles. If we thought that normatively doubtful claim-disposing duty determinations ought to be cast in rule form, then we would dishonor a judge who made up a rule to dispose of a case knowing that the rule was good only for the specific case.

The concern to preserve the role of the jury as fact-finder coupled with the procedural difficulty of separating issues of fact from normative issues in administering a standard is the most obvious justification for this rule..$^{117}$ The special verdict and the general verdict with special interrogatories are the devices available to obtain specific factual findings from the jury in advance of the normative determination by the judge. (If the judge is to make the normative determination of what is inappropriate conduct in advance of the jury's factual findings we are back to where we started, for he must formulate a rule or standard that the jury can apply."15) But these devices are not well suited to getting the information that is necessary to evaluate conduct into the hands of a judge. The usual reasons for evaluating conduct by a standard rather than a rule is that the judgment is fact-dependent, meaning that there are a large number of potentially relevant variables, the relation among these variables is complex, and/or important variables cannot be specified in advance. ${ }^{119} \mathrm{~A}$ standardized special verdict form or special

116. See, e.g., Cobo v. Robo, 195 S.E.2d 362 (N.C. 1998) (stating North Carolina standard on efficiency of evidence to support verdict); Stafford v. Stafford, 726 S.W.2d 14, 16 (Tex. 1987) (stating Texas standard).

117. See Stephen A. Weiner, The Civil Jury Trial and the Law-Fact Distinction, 54 Cal. L. Rev. 1867, 1922 (1966) (arguing that the jury should administer reasonableness standards).

118. On the use of these devices in federal court and a description of the mixed success of states with special verdicts, see 9 Wright \& Miller, supra note 73, at \$2502. See also Edmund M. Morgan, A Brief History of Special Verdicts and Special Interrogatories, 32 Yale L.J. 575, 576-77, 588 (1923) (concluding that "the special verdict had its origin in the desire of the jury to avoid the responsibility of determining questions of law" because it originated in a time when the jury could be punished for rendering a false verdict even when the error went to an obscure point of law).

119. Some of the literature is collected. See supra note 1 and accompanying text. 
interrogatories would have to be of Byzantine complexity to account for all possible variables and their relation in the usual negligence case, and the form still would not be complete. Counsel and the trial judge might try to winnow out questions about irrelevant variables and add questions, but this process would be cumbersome. It would invite side arguments and create opportunities for strategic behavior by counsel, and opportunities for reversible error. This point should not need belaboring because it seems self-evidently desirable to keep together the task of fact-finding and the task of evaluating conduct when the evaluation of conduct is intensely fact-dependent. ${ }^{120}$

But the concern to preserve the role of the jury as fact-finder does not quite justify the proposed rule and is not sufficient to explain how power is allocated between judge and jury in negligence law. This concern requires putting the issue of what is reasonable conduct to the jury only in cases where normative doubt is coupled with factual doubt. Where there is only normative doubt about what is reasonable conduct, a judge could decide the issue without intruding on the role of the jury as fact-finder. This possibility most clearly arises in a case where the facts are undisputed but breach is contested. In negligence law, the issue of breach goes to the jury in such a case. ${ }^{121}$

There are more far-reaching implications to justifying the power of a jury to administer a standard solely on the principle that the jury should decide doubtful facts. Consistent with this principle a judge could dispose of a claim without specifying how precisely he resolved a doubtful normative issue so long as he was confident that his answer did not depend on a doubtful fact. The significance of allowing judges such a power can be seen in a Washington case involving a customer

120. One way to deal with this problem would be to have the judge and jury deliberate together under ground rules that allow the jury to take the lead in constructing a narrative about what occurred, with the judge advising the jury about what points to address in the narrative and stating the legal conclusion.

121. See Rail Road Co. v. Stout, 84 U.S. 657, 663-65 (1873) (involving the question whether a railroad was negligent in maintaining a turntable that children could play on, and answering it with one of the most famous eulogies to the moral wisdom of juries); see also Ellington v. Tolar Constr. Co., 227 S.E.2d 336, 338 (Ga. 1976) ("Even where there is no dispute as to the facts, it is, however, usually for the jury to say whether the conduct in question met the standard of the reasonable man." (citation omitted)); Mitchell v. Ankney, 396 N.W.2d 312, 313 (S.D. 1986) (stating that a jury should determine whether defendants breached any duty of reasonable care); Restatement (Second) of Torts § 328(c) (1965) (considering the determination of "(a) the facts [and] (b) whether the defendant has conformed to the standard of conduct required by the law" to be separate functions of the jury). But see Smith v. Kerns, 931 P.2d 717, 719 (Mont. 1997) ("A district court is only to determine whether a defendant is negligent when evidence is undisputed or susceptible to only one conclusion by reasonable people."); O'Connor v. Corbett Lumber Corp., 352 S.E.2d 267,270 (N.C. Ct. App. 1987) ("What is negligence is a question of law and when the facts are not disputed, the court must say whether negligence does or does not exist."). 
robbed and hurt outside a store.12 The customer claimed that it was unreasonable for the store not to post a security guard. ${ }^{13}$ The majority held that there was no duty on the facts, but it did not lay down a bright-line rule, recognizing that prior experience at the store, the character of the neighborhood, the time of day, and the character of the clientele might make it reasonable to post a guard. ${ }^{124}$ If the decision is questionable, it is so on normative grounds: people might well disagree about how much responsibility merchants have to protect their customers from danger from outside elements. But once the majority decided that the degree of responsibility was slight, there was no factual doubt regarding the outcome in the specific case because it seems to have been undisputed that there had been no prior incidents near the store. ${ }^{125}$ If our only concern was that judges not infringe on the role of the jury as fact-finder in making duty determinations, then this sort of ad hoc no-duty determination would be appropriate given the absence of factual doubt.

That the issue of breach is put to the jury even when facts are free of doubt shows that in negligence law independent value is put on the jury deciding what is reasonable conduct when the normative issue is open to debate. This is where what I call the values of popular judgment come into play. The many celebrations of the jury's role in negligence focus more on the jury's role in deciding normative issues than the jury's role in deciding factual issues. ${ }^{125}$ The civil jury's virtues are said to include (with considerable overlap):127 (1) keeping the law

122. See Nivens v. 7-11 Hoagy's Corner, 943 P.2d 286, 294 (Wash. 1997) (Sanders, J., dissenting).

123. See id. at 288.

124. See id. at $293-94$

125. See id at 288.

126. Many observers have concluded that the institution of the jury is dificult to explain as a product of a desire for accuracy in fact-finding. Instead, they find the value of the jury in securing popular judgment. See Atiyah \& Summers, supra note 1, at 174-75; see also Wolfram, supra note 43, at 671-72 (arguing that this was also the view of the anti-federalists who fought for the seventh amendment, and concluding that " $[t]$ hose who favored the civil jury were not misguided tinkerers with procedural devices; they were, for the day, libertarians who avowed that important areas of protection for litigants in general, and for debtors in particular, would be placed in grave danger unless it were required that juries sit in civil cases." (footnote omitted)). Wolfram tells a nuanced story drawing on reports from the state constitutional conventions. He observes that the defense of the right to jury trial was usually joined with pleas for debtors oppressed by non-local creditors, with no one ever explicitly arguing that the jury was to protect the creditors. See Wolfram, supra note 43 , at 673 77. He concludes that the speakers were troubled by the prospect of the jury finding against the law. See id. at 704-05.

127. See 9 Wright \& Miller, supra note 73, § 2301 (collecting some classic culogies to the jury); Leon Green, Jury Trial and Mr. Justice Black, 65 Yale LJ. 482, 483-88 (1956) [hereinafter Green, Jury Trial] (stating eloquently many of these arguments). Of course, there are corresponding vices to giving the jury a large role, including cost, the accompanying formalization of trial procedures and restrictions on evidence, bringing more passion and prejudice into the administration of the law, unpredictability, and the burden on jurors themselves of service. See Paul D. 
in touch with popular values;,128 (2) serving as a guard against excessive rigidity in the law;129 (3) independence; (4) the symbolic value of rule by the people; $;^{130}(5)$ the advantage of numbers in decision-making:;11 (6) the expertise ordinary people bring ${ }^{132}(7)$ providing judges political cover for unpopular decisions; ;133 (8) education of the people about the law through jury service, ${ }^{134}$ and (9) the greater drama a jury trial brings to the administration of justice. ${ }^{135}$ The first two virtues rest almost

Carrington, The Seventh Amendment: Some Bicentennial Reflections, 1990 U. Chi. Legal F. 33, 39-41 (stating well the case against the civil jury).

128. See Abramson, supra note 70 , at $2-13$ (making an eloquent and thoughtful non-academic defense of the jury as an institution of deliberative democracy); Green, Jury Trial, supra note 127, at 483 ("It offers an assurance of judgment by neighbors who understand the community climate of values... and a means of softening the cold letter of the law in cases of hardship."); James, Functions of Judge, supra note 78, at 685-87 (emphasizing that the jury's virtue is in its ability to keep the law in touch with popular culture).

129. See Bohlen, supra note 78, at 116; Guido Calabresi \& Philip Bobbitt, Tragic Choices 57-64 (1978) (identifying a related virtue and some accompanying vices that are a product of the combination of the unexplained nature of jury decisions and the representativeness of the jury). Their basic point is that we as a society are uncomfortable with the choices among competing values in difficult decisions, and so we prefer that decisions be unexplained. See Calabresi \& Bobbitt, supra, at 57 (" $[G]$ iving no reasons, it avoids, or at least mitigates, the conflict between the wish to recognize differences and the desire to affirm egalitarianism in all its forms."). The authors argue that this arrangement is unstable if decisions recur because either the decisions will form a pattern revealing the rationale or they will come to seem arbitrary.

A related argument is that moral judgments in negligence are given to the jury because we believe that there are multiple valid moral viewpoints from which to resolve negligence claims. See Wells, supra note 79, at 2402-03. Wells argues that through group deliberation and the need for consensus the jury counteracts individual perceptive biases and diverse moral viewpoints, (hopefully) producing results that meet a criteria she labels "local objectivity," meaning that people with different viewpoints will come to agree on the outcome in the specific case. See id. at 2408-10. Wells focuses on differences in moral viewpoints among individuals. See id. at 240203. Calabresi and Bobbitt consider the conflict internal to the individual. See Calibresi \& Bobbitt, supra, at 17-28.

130. See Green, Jury Trial, supra note 127, at 483 (arguing that the jury is "a symbol of political freedom, emphasizing the dignity of the citizen and the power of the local community").

131. See Michael J. Saks, Do We Really Know Anything About the Behavior of the Tort Litigation System-And Why Not?, 140 U. Pa. L. Rev. 1147, 1237-39 (1992) (emphasizing this and the next factor in explaining why "[a] considerable body of research both on actual juries and in well controlled trial simulations supports the conclusion that juries make reasonable and rational decisions" (footnote omitted)). Saks's main point is that we know very little about the operation of the tort system and much that we think we know is probably wrong. See id. at 1149.

132. See Railroad Co. v. Stout, 84 U.S. 657,664 (1873).

133. See Green, Jury Trial, supra note 127 , at 483 ("[T] jury verdicts relief from making embarrassing judgments and protection against the criticism that arises from an unpopular outcome of a trial.").

134. See Alexis De Tocqueville, Democracy in America, Vol. I 291-297 (Henry Reeves trans., as rev. by Francis Bowen, Vintage Books 1945) (1835).

135. See Green, Judge and Jury, supra note 67, at 395 (making this argument superbly); Marc Galanter, The Regulatory Function of the Civil Jury, in Verdict: 
entirely on the jury acting as moral arbiter and very little on it acting as fact-finder; while the next five rest at least partially on the jury acting as moral arbiter. P.S. Atiyah puts much of this in a nutshell in observing that the unusual significance of tort law in America and the large role played by the jury is a product of American anti-statism, distrust of centralized power, and distrust of rule by elites. ${ }^{135}$

Were we to accept that a commitment to popular judgment requires that doubtful normative issues be put to the jury in negligence law, the implications would be significant. It would mean that a judge could not replace the reasonably prudent person standard with the Hand formula unless he thought that this was not open to moral debate. Also, a judge could not decide the issue of breach even though he could formulate a bright-line rule to justify his decision unless he thought the underlying normative judgment was not in doubt. Negligence law does not go this far. A few courts have said that before a rule of conduct can be laid down there must be a careful balancing of concerns of policy and fairness, ${ }^{13}$ and that the rule must be "clearly supported by public policy."13s But this is as far as courts have gone in suggesting that judges ought to leave normatively difficult issues for the jury to resolve, given the intended purposes of juries. Usually courts seem untroubled by the reduction in the normative discretion of a jury resulting from the substitution of a rule of conduct or a less open-ended standard for the reasonably prudent person standard. There are areas within accident law where the standard of fault is cast in terms that do ask for a less open-ended moral inquiry. In professional malpractice the standard is custom. ${ }^{139}$ In products liability the dominant standard for design and warning defects is risk-utility. ${ }^{140}$ There has not been a hew and cry that these

Assessing the Civil Jury System 61, 89 (1993) ("Juries impede the collapse of individualized decisionmaking into the stereotyping, cooperation and trade-offs of routine processing ....").

136. See P.S. Atiyah, Tort Law and the Alternatives: Some Anglo-American Comparisons, 1987 Duke L.J. 1002, 1017-18, 1043-44.

137. See Tarasoff v. Regents of Univ. of Cal., 551 P.2d 334, 342 (Cal. 1976).

138. Rowland v. Christian, 443 P.2d 561, 564 (Cal. 1968).

139. The practical effect of the standard is that a plaintiff must produce expert testimony from a person within the defendant's specialty or school of medicine. See Melville v. Southward, 791 P.2d 383, 391 (Colo. 1990) (holding that testimony of an orthopedic surgeon does not suffice in suit against podiatrist for malpractice in foot surgery).

140. See Prentis v. Yale Mfg. Co., 365 N.W.2d 176, 184 (Mich. 1984) (describing risk-utility as "merely a detailed version of Judge Learned Hand's negligence calculus"); Restatement (Third) of Torts: Products Liability $\$ 2$ (1998). Oddly, several cases hold that it is not reversible error to fail to give a negligence instruction where the plaintiff brings a negligence claim as well as a design defect claim because the risk-utility instruction covers the same ground. See Lovick v. Wil-Rich, 588 N.W.2d 688, 699 (Iowa 1999); Estate of Hunter v. General Motors Corp., 729 So. 2d 1264, 1277 (Miss. 1999); see also St. Germain v. Husqvarna Corp., 544 A.2d 1283, 1286 (Me. 1988) (holding that it was not reversible error to fail to submit design defect claim to the jury because negligence instruction expressed standard as risk-utility). It 
standards intrude upon the moral discretion of the jury. And when judges have tried to formulate rules to define the standard of conduct in a given situation, the usual complaint is that the rules do not work, and not that the very enterprise of formulating a rule intrudes upon the role of the jury as moral arbiter. ${ }^{141}$

To justify this odd pattern - the jury decides fault even when no fact is in doubt but there is no impediment to a judge taking the normative issue from the jury by laying down a rule or a more precise standardit is useful to think of power being allocated between judge and jury by weighing competing values on a scale. On one side of this scale are the values of popular judgment. On the other side are the values of satisfying what Lon Fuller described as the demands of the "inner morality of law"-"make the law known, make it coherent and clear, see that your decisions as an official are guided by it, etc." ${ }^{142}$

Once the matter is thought of in this way it makes a great deal of sense why a judge can decide what is inappropriate conduct in a case where people could reasonably disagree on the matter only if he can do so by formulating a rule or standard that applies beyond the immediate case. The inability to resolve a doubtful normative issue through a rule or standard that reduces doubt and discretion in future cases removes Fuller's values from the balance, and so swings the scale decisively in favor of having the jury decide what is inappropriate conduct because of the value we place on popular judgment. Coming at it from the other side, we place such a high store on Fuller's values that the value of having a rule or a more certain standard will always swamp the value of popular judgment. Those courts that go further and insist that a normative issue can be taken from a jury only if the answer is "clearly supported by public policy" can be thought of as placing more relative value on popular judgment on difficult normative issues and less relative value on making the law known, coherent, and clear.

As we leave negligence law to examine other areas of law we will find that judges often do make ad hoc decisions regarding culpability or obligation. This begins right at the boundaries of negligence. Some courts in replacing one of the traditional no-duty rules with a standard have left it to the judge to administer the standard. ${ }^{143}$ These decisions will seem less idiosyncratic after we examine contract law

is difficult to square these cases with cases holding that it is reversible error to give a reasonableness instruction in a design defect case because the manufacturer is entitled to a risk-utility instruction. See Ford Motor Co. v. Miles, 967 S.W.2d 377, 386-88 (Tex. 1998).

141. See Pokora v. Wabash Ry. Co., 292 U.S. 98, 102-03 (1934) (criticizing the "stop, look, and listen" rule laid down by Justice Holmes in Baltimore \& Ohio Railroad Co. v. Goodman, 275 U.S. 66, 69 (1927), without faulting Holmes for having infringed on the role of the jury).

142. Lon L. Fuller, The Morality of Law 42 (rev. ed. 1969).

143. See supra notes $97-110$. 
for in contract law the jury is given virtually no say on normative issues. Traditionally, this has been so even when an issue is resolved on an ad hoc basis. I infer from this that in the realm of contract law professional judgment on normative issues is valued over popular judgment for reasons that, in some respects, are independent of the value of having a rule. Juries are also given no say on normative issues in administering doctrines in tort and restitution that protect economic interests, with the singular exception of the doctrine of abuse of a confidential relationship.

\section{B. Intentional Torts}

Historically, the jury has had little say on normative issues in administering the torts of battery, assault, trespass, and conversionthe primary torts redressing intentional physical injuries-except in assessing punitive damages (admittedly a rather big exception). This is because these torts take the form of categorical rules that, on their face, ask for no normative judgment at the point of application. Normative considerations can, and probably do, influence decisions made in the administration of these rules in cases where the terms of the rule apply ambiguously. It is assumed that judges resolve these definitional issues. For example, the judge decides whether grabbing a tray out of a person's hand is a touching of their person that could be a battery ${ }^{144}$ and whether emitting light or gas on a person's land is a sufficient physical invasion to be a trespass. ${ }^{145}$

When an intentional tort to person or property takes a form that does ask for normative judgment at the point of application, the normative issue is given to the jury. For example, one definition of battery makes the offensiveness of a touching an element. ${ }^{165}$ This issue is for the jury. ${ }^{147}$ The issue of what is outrageous conduct under the tort of intentional infliction of emotional distress is also given to the jury in most states. ${ }^{148}$ The willingness to turn these issues over to the jury suggests that the small role the jury has played historically in deciding normative issues under the intentional physical torts is a product of the law's form, or, more precisely, our desire for rules, and

144. See Fisher v. Carrousel Motor Hotel, Inc., 424 S.W.2d 627, 629 (Tex. 1967).

145. See Martin v. Reynolds Metals Co., 342 P.2d 790, 797-98 (Or. 1959); Amphitheaters, Inc. v. Portland Meadows, 198 P.2d 847, 858 (Or. 1948). This presents a bit of a puzzle. How is the determination that an event is a "touching" different from the determination that an event is "foreseeable," which is assumed to be a question for the jury? I think the difference is that the term "foreseeability" is vague through and through while the term "touching" seems to have a determinate meaning until we are confronted with a doubtful case. We think that in defining touching in the odd case the judge is refining the rule even though the odd case may not recur.

146. See Restatement (Second) of Torts § 18(1) (1965).

147. See Whitley v. Andersen, 551 P.2d 1083, 1085 (Colo. Ct. App. 1976); Snyder v. Turk, 627 N.E.2d 1053, 1058 (Ohio Ct. App. 1993).

148. See Gergen, Grudging Defense, supra note 96, at 1703-13. 
nothing else. We seem comfortable with ordinary intuitive morality in this area once we choose to forego rules.

The history of the tort of intentional infliction of emotional distress has another lesson to teach. ${ }^{149}$ Before the infliction tort was created judges stretched the torts of battery, assault, and trespass to provide redress for outrageous conduct that inflicted severe mental anguish. ${ }^{\text {sso }}$ Advocates of the infliction tort argued that one of its virtues was its transparency. The decisions stretching the categorical torts had a spurious quality because judges were seen as manipulating rules based on moral judgments that had no referent in the terms of the rules. Transparency seems an unalloyed good. But the law is littered with spurious rules. Years ago, Leon Green said that the law of fraud had this character. ${ }^{151}$ Green could have said the same thing about much of contract law in his day (particularly the parol evidence rule, about which this can still be said ${ }^{152}$ ) or the law of negligence regarding the obligations of landowners. ${ }^{153}$ A sometimes overlooked virtue of spurious rules is that they enable the judge to decide factual or normative issues that might otherwise have to go to the jury. If we are to do away with spurious rules without turning a great deal of power over to the jury, then we must separate who decides an issue from the form in which the decision is cast.

\section{CONTRACT LAW}

In classical contract law, the jury had no normative role in deciding obligation. Because the key issues of assent, meaning, and damages

149. See Keeton, supra note 92, at 64-69 (discussing the effects of the shift from "particularized" to "generalized" doctrine).

150. See Gergen, Grudging Defense, supra note 96 at 1704-06.

151. See Green, Judge and Jury, supra note 67, at 311 ("[T] he elaborate formula with its multitude of sub-formulas with their variations which have been evolved, permit the judge to range as freely as his judgment dictates.").

152. The concepts of integrated agreement, completely integrated agreement, and inconsistent and collateral terms all have an elastic meaning and are issues for the judge. See John Henry Wigmore, Wigmore on Evidence $\$ 2426$ (1940). Section 2426 states in part:

[T] he rigid control of the jury influenced the judges, indirectly, by leading them to keep from the jury all alleged oral transactions which might be misused by them to overturn the words of the writing.... If the parties were allowed to put in averments extraneous to the writing, it must go to the jury, and there was no telling what the jury might do; but if the judges took See id.

exclusive charge, they could better control the situation.

153. See Prosser \& Keeton, supra note $113, \S 62$, at $432-34$ (commenting that while the traditional rules were seen as "harshly mechanical, unduly complex, and overly protective of property interests," the movement to abolish them "came to a screeching halt" in 1979, in part due to dissatisfaction with the "shifting of the decisional balance of power to the jury from the judge"); see also James A. Henderson, Jr., Expanding the Negligence Concept: Retreat from the Rule of Law, 51 Ind. L.J. 467, 468-69 (1976) [hereinafter Henderson, Expanding] (warning that principled decision-making may be replaced with decisions by whim). 
are, at their core, issues of fact, we might have expected the jury to play a large role in deciding obligation in contract. ${ }^{\text {ss }}$ But everywhere in classical contract law the jury was hemmed in by rules. The classical law of offer and acceptance consisted of a set of highly formal rules that enabled the judge to decide the issue of assent in many cases. The mirror image rule, which requires that an acceptance precisely mirror an offer to be effective, was a familiar example of such a rule. ${ }^{155}$ The doctrine of indefiniteness ${ }^{156}$ and the doctrine requiring that damages be proven with reasonable certainty's both enabled a judge to take from the jury the issues of interpretation and damages when he thought that there was too much uncertainty about the answer. These doctrines have weakened considerably in this century. ${ }^{158}$ Still, some formal rules persist. For example, the Statute of Frauds eliminates entire categories of claims that the "common man" might be sympathetic to, most obviously in the employment area. ${ }^{199}$

154. Some quasi-factual issues are decided by the judge. One of these is the existence of consideration to support enforcing a promise. See State v. Larsen, 515 N.W.2d 178, 181 (N.D. 1994); Brownwood Ross Co. v. Maverick County, 936 S.W.2d 42, $45-46$ (Tex. App. 1996); Beesley v. Harris, 883 P.2d 1343, 1351 (Utah 1994); Lloyd's Credit Corp. v. Marlin Management Servs., Inc., 614 A.2d 812, 815 (Vt. 1992); Nationwide Mut. Fire Ins. Co. v. Watson, 840 P.2d 851, 860 (Wash. 1992). But see Hill v. Chubb Life Am. Ins. Co., 894 P.2d 701, 707 (Ariz 1995) (stating that the adequacy of consideration is a factual question). Under the bargain theory, consideration should be a factual issue.

Another, more normative, issue decided by the judge is whether reliance is such that justice requires enforcement of a promise not supported by consideration. See Cohen v. Cowles Media Co., 479 N.W.2d 387, 392 (Minn. 1992) (holding that justice required enforcement of a reporter's promise of confidentiality to source); Hoffman v. Red Owl Stores, Inc. 133 N.W.2d 267, 275 (Wis. 1965). The historic roots of promissory estoppel in equity have led some courts to treat the entire matter as an issue for the judge.

155. See Restatement (Second) of Contracts $\S 59$ (1979).

156. See Weddington Prods., Inc. v. Flick, 71 Cal. Rptr. 2d 265, 278 (Ct. App. 1998) (holding that uncertainty was too great to make contract enforceable); Oceanmark Bank, F.S.B. v. Stubblefield, 496 S.E.2d 465, 467 (Ga. Ct. App. 1998) (same); America's Favorite Chicken Co. v. Samaras, 929 S.W.2d 617, 621 (Tex. App. 1996) (holding that the essential terms were sufficiently definite to enforce the contract); Shetney v. Shetney, 181 N.W.2d 516, 521-22 (Wis. 1970) (holding that uncertainty was too great to make the contract enforceable). But see Management Computer Servs., Inc. v. Hawkins, Ash, Baptie \& Co., 557 N.W.2d 67, 75 (Wis. 1996) (stating that issue of indefiniteness may be decided by judge or jury).

157. See Chicago Coliseum Club v. Dempsey, 265 Ill. App. 542, $549-50$ (1932) (holding that a plaintiff was not allowed to use expert testimony to prove lost profits on a boxing match because the matter was too speculative); Coonis v. Rogers, 429 S.W.2d 709, 714 (Mo. 1968) (holding the same for commercial businesses); Cell, Inc. v. Ranson Investors, 427 S.E.2d 447,450 (W. Va. 1992) (holding the same for grocery sales). It is difficult to find a recent decision in which a judge takes the question of damages from the jury on this ground where there is some evidence of damages.

158. Robert A. Hillman reviews the history of the decline of rules and the ascendance of standards in contract law this century by tracing the ongoing conflict between contextualists (proponents of standards) and neo-formalists (proponents of rules). See Robert A. Hillman, The Richness of Contract Law 125-71 (1997).

159. Courts that follow the Restatement (Second) of Contracts section 139 by 
Karl Llewellyn, the principal author of the Uniform Commercial Code, advocated a less rule-bound and more flexible approach to determining assent, meaning, and damages, and his views are reflected in the text and commentary of the Code. ${ }^{160}$ Llewellyn understood that such an approach placed greater reliance on the fact-finder and so he proposed using merchant juries to resolve disputes between merchants. His proposal was rejected. ${ }^{161}$ A significant issue facing contract law in the future is whether the shift from rules to standards will increase the jury's role so that eventually the jury will play a significant role in shaping the morality of contract law. ${ }^{162} \mathrm{~A}$ related issue is whether fear of the jury will induce judges to embrace an overly rule-bound approach.

\section{A. Classical Contract Law}

Interpretation is the logical place to start in analyzing the division of power between judge and jury to decide obligation in contract law, for it is here that the issue is faced most squarely. While interpretation is a question of fact, it can be influenced by the values of the interpreter. Judge Cardozo famously made this point in holding that a term should not be interpreted as a condition when it would result in disproportionate forfeiture. ${ }^{163} \mathrm{He}$ observed that "[f]rom the conclusion that promises may not be [so] treated... without a sacrifice of justice, the progress is a short one to the conclusion that they may not be so treated without a perversion of intention."164 The fact that interpretation can be influenced by the values of the

making an exception to the Statute of Frauds to protect reliance treat the question of whether justice is furthered by making an exception as for the judge. See, e.g., Stearns v. Emery-Waterhouse Co., 596 A.2d 72, 74 (Me. 1991) (holding that justice is not furthered by making an exception to protect an employee who alleged an oral promise of job security).

160. See U.C.C. $\S 1-106(1) \mathrm{cmt} .1$ (1999) ("[R] jeject[ing] any doctrine that damages must be calculable with mathematical accuracy."); id. \$ $1-205 \mathrm{cmt}$. 1 (stating that courts should look to "commercial context" to "explain and supplement even the language of a formal or final writing"); id. \$ 2-202 cmt. 1 (rejecting the "plain meaning" rule and the "four-corners" rule in interpretation); id. \$ 2-204(3) (stating that a contract shall not fail for indefiniteness so long as there is a reasonably certain basis for a remedy); id. §2-207 (abolishing the "mirror-image" rule).

161. See generally Dennis M. Patterson, Good Faith, Lender Liability, and Discretionary Acceleration: Of Llewellyn, Wittgenstein, and the Uniform Commercial Code, 68 Tex. L. Rev. 169, $202-09$ (1989) [hereinafter Patterson, Good Faith] (telling Llewellyn's story); Zipporah Batshaw Wiseman, The Limits of Vision: Karl Llewellyn and the Merchant Rules, 100 Harv. L. Rev. 465, 512-15 (1987) (same).

162. See Atiyah \& Summers, supra note 1, at 83-88 (observing the shift from rules to standards in American contract law); Melvin Aron Eisenberg, The Responsive Model of Contract Law, 36 Stan. L. Rev. 1107, 1167 (1984) ("[I]n modern times, contract theory has evolved away from the rigidities of the classical model, into a supple instrument consisting of principles that are intellectually coherent but also responsive to intentions and circumstances.").

163. See Jacob \& Youngs, Inc. v. Kent, 129 N.E. 889, 891 (N.Y. 1921).

164. Id. 
interpreter is not thought to give the jury the prerogative to impose its values through interpretation. Quite the opposite. In fact, a concern that the personal values of jurors may influence interpretation is thought to be a reason for constraining the role of the jury in interpretation. ${ }^{165}$

The assumption that the jury should not impose its values in interpreting contracts underlies the distinction Corbin drew between contract interpretation and contract construction. Corbin defined interpretation as deciding what the parties actually intended and construction as deciding what, as a matter of policy or fairness, was reasonable. ${ }^{166}$ Thus, he treated gap-filling as contract construction because terms were implied based on what was reasonable, rather than on what the parties intended. ${ }^{167}$ Corbin said that construction is always a matter for the judge ${ }^{16 s}$ while interpretation is sometimes for the jury..$^{169}$

Power is allocated between judge and jury in contract interpretation primarily by rules that restrict the evidence used in interpretation and give the judge power to interpret certain types of evidence. At one extreme is the infamous "four-corners" rule, which forbids looking beyond a written agreement when it is not ambiguous on its face, making the interpretation of an unambiguous writing an issue for the judge. ${ }^{170}$ The four-corners rule and its cousin, the "plain meaning" rule, which holds that words of plain and unequivocal meaning are so construed without regard to the parties' actual intent, ${ }^{\text {nh }}$ have fallen

165. See Charles T. McCormick, The Parol Evidence Rule as a Procedural Device for Control of the Jury, 41 Yale L.J. 365, 366-69 (1932).

166. See 3 Arthur L. Corbin, Corbin on Contracts \& 534, at 9 (1960) [hereinafter Corbin, Corbin on Contracts] ("By 'interpretation of language' we determine what ideas that language induces in other persons. By 'construction of the contract,' as that term will be used here, we determine its legal operation. ..."). Later statements show that Corbin thought that construction was driven by concerns of social policy. See id. § 534, at 14. The gray zone between interpretation and construction is where the parties' understanding is determined by imaginatively putting oneself in their position and asking how one would feel. See id. $\S 536$, at 34-35. Corbin calls this "interpretation" though he concedes that the meaning chosen was probably "that [which] some imaginary reasonable, prudent, and intelligent man would have had." Id. § 536, at 35; see also Lawrence A. Cunningham \& Arthur J. Jacobson, Corbin on Contracts $\S 554 \mathrm{~B}$, at 357 (Supp. 1999) ("Some doctrines of contract interpretation are not designed to find the intentions of the parties, but to advance social policies which are in need of judicial protection."); Edwin W. Patterson, The Interpretation and Construction of Contracts, 64 Colum. L. Rev. 833, 837-38 (1964) [hereinafter Patterson, Interpretation] (following Corbin in insisting on the usefulness of the distinction between interpretation and construction). Patterson gives as an example of construction determining whether a term is unfair, which, he says, is a court's exclusive function. See id. at 838 . Another example of construction is the principle of contra proferentem. See id. at 835.

167. See 3 Corbin, Corbin on Contracts, supra note 166, $\S 534$, at 11-12.

168. See id. $\$ 554$, at 227.

169. See id. \& 554, at 222-23.

170. See Air Safety, Inc. v. Teachers Realty Corp., 706 N.E.2d 882, 884 (IIl. 1999).

171. See 2 William F. Elliott, Elliott on Contracts, \& 1506, at 775 (1913) (giving a 
out of favor in most states. ${ }^{172}$ Even with the demise of the "fourcorners" rule the role of the jury in interpretation is constrained in various ways. Some states allow a judge to consider extrinsic evidence in deciding whether a writing is ambiguous. ${ }^{173}$ Broadening the evidence considered tends to eliminate ambiguity for often doubt about the meaning of words is eliminated once they are put in context. Interpretation becomes an issue for the judge on the general principle that the judge decides factual issues about which there is no doubt. ${ }^{174}$ Some states make the interpretation of even an ambiguous written agreement an issue for the judge when extrinsic evidence is not relevant. 175 Other states make interpretation an issue for the judge

strong statement of this rule). Critics of the objective interpretation rule have argued that the rule was grounded on a naïve view of language. See, e.g., Arthur L. Corbin, The Interpretation of Words and the Parol Evidence Rule, 50 Cornell L.Q. 161, 187 (1965) [hereinafter Corbin, Interpretation] (advocating the use of extrinsic evidence for contractual interpretation). The old treatises do not bear this out. The rule is justified instead by necessity: there is no better evidence. See Wm. L. Clark, Jr., Clark on Contracts $\$ \$ 240-44$, at 564-65 (1894). Pollock develops this argument more fully. He argues that the rule gets at the parties' actual understanding in nearly all cases and that it is better to live with the occasional injustice than to open up the issue of interpretation in all cases. See Frederick Pollock, Pollock on Contracts 260-61 (8th ed. 1911).

172. See U.C.C. \& 2-202 cmt. 1(b) (1999) (rejecting the plain meaning rule); Restatement (Second) of Contracts $\S \S 202(1), 214$ (c) (1979) (same); 3 Corbin, Corbin on Contracts, supra note 166, at $\S 542 ; 4$ Samuel Williston \& Walter H. E. Jaeger, A Treatise on the Law of Contracts $\S 600 \mathrm{~A}$, at 299 (3d ed. 1961) ("In interpreting contracts or clauses set forth in 'clear and unambiguous' language, the courts do not confine themselves to a mere inspection of the document. Before committing themselves, the courts carefully examine the surrounding circumstances, prior negotiations, and all other relevant incidents bearing on the intent of the parties.").

The First Restatement of Contracts adopted an objective standard for interpreting unambiguous writings. See Restatement (First) of Contracts $\$ 230$ (1932). A writing was read from the perspective of an intelligent observer even though that reading diverged from the parties' actual understanding so long as the meaning was unambiguous. See id. $\S 230 \mathrm{cmts}$. b, h. But it rejected the plain meaning rule. See id. The observer was assumed "to have knowledge of all operative usages [ ] as well as of other accompanying circumstances." Id. $\S 230 \mathrm{cmt}$. a. Ambiguous writings were interpreted under the same standard as unwritten contracts by taking account of the parties' actual understanding. See id. \$§ 231 \& 233.

173. See Pesino v. Atlantic Bank of N.Y., 709 A.2d 540, 545 (Conn. 1998); Freelander v. G. \& K. Realty Corp., 258 N.E.2d 786, 788 (Mass. 1970); Moller v. State Farm Mut. Auto. Ins. Co., 566 N.W.2d 382, 385 (Neb. 1997); Border States Paving, Inc. v. State, 574 N.W.2d 898, 902 (S.D. 1998); Coker v. Coker, 650 S.W.2d 391, 393 (Tex. 1983); United Ry. Supply \& Serv., Ltd. v. Boston \& Maine Corp., 535 A.2d 325, 327 (Vt. 1987); W.J. Schafer Assocs., Inc. v. Cordant, Inc., 493 S.E.2d 512, 515 (Va. 1997).

174. See 3 Corbin, Corbin on Contracts, supra note $166, \S 554$.

175. Under this rule, the judge interprets an ambiguous written agreement if no probative extrinsic evidence is introduced. See Schoemer v. Hanes \& Assocs., 693 N.E.2d 1333, 1339 (Ind. Ct. App. 1998); Univ. Nat'l Bank v. Wolfe, 369 A.2d 570, 575 n.7 (Md. 1977); Tumer v. Alpha Phi Sorority House, 276 N.W.2d 63, 66 (Minn. 1979). This seems to be the position of the Restatement (Second) of Contracts. See Restatement (Second) of Contracts $\S 212(2)$ (stating that the interpretation of an integrated agreement is to be determined as a question of law unless "it depends on 
even if extrinsic evidence is relevant so long as there is no issue of credibility. ${ }^{176}$ Overlaying these rules defining the role of judge and jury are other rules limiting the interpretive discretion of both judge and jury. One such rule requires that an obligation implied from trade usage or custom be fairly specific and that it be proven by objective evidence. ${ }^{17}$

the credibility of extrinsic evidence or on a choice among reasonable inferences to be drawn from extrinsic evidence"); see also 4 Williston, supra note $172, \S 616$, at 663 (taking the same position as the Restatement).

Justice Newman's concurrence in Antilles S.S. Co., v. Members of American Hull Insurance Syndicate is a thoughtful attempt to justify this rule. See 733 F.2d 195, 20405 (2d Cir. 1984). He makes several arguments. According to Judge Newman, the judge is making law by saying how certain words will be read. See id. Corbin derided the view that in interpreting contracts judges gave words a legal meaning. See 3 Corbin on Contracts, supra note 166, § 554, at 219 n.60. His view was that legal precedent was relevant to interpretation only if there was a reason to believe the parties had that precedent in mind in contracting. See id. Better arguments made by Judge Newman include the need for certainty in contract, the expertise of judges, and the non-factual character of many contract disputes. See id. at 220. Judge Newman notes the contrast of the practice in contract law with that in negligence law, and justifies it by the greater need for certainty in contract law. In Antilles, he stated that:

On the contrary, rather than wish for the leavening influence of a jury to decide in tort cases under what circumstances a person's conduct should render him liable for another's injuries, we should deem it in the public interest in contract cases to have as much certainty as possible as to the meaning of contracts, especially those involving terms used by others beyond the contracting parties. And, unlike most tort cases, the facts of a contract breach are frequently undisputed, requiring determination only of the applicable standard to be derived from the words of the contract.

Antilles, 733 F.2d at 206-07. A variation on this rule does not restrict it to the interpretation of a writing. The judge interprets an agreement whether it is written or oral when interpretation involves giving meaning to words and the words themselves are not in dispute. Clear statements of this rule can be found in old treatises. See Clark, supra note 171, § 240; Elliott, supra note 171, $\$ 1564 ; 4$ William Herbert Page, Page on the Law of Contracts $\$ 2061$ (2d ed. 1920).

176. Under this rule the judge interprets an agreement where all the evidence is documentary even if extrinsic evidence is relevant. See Parsons v. Bristol Dev. Co., 402 P.2d 839, 842 (Cal. 1965) (en banc); Jordan v. Patterson, 35 A. 521, 522-23 (Conn. 1896); Mallad Constr. Corp. v. County Fed. Sav. \& Loan Ass'n, 344 N.Y.S.2d 925, 932 (1973); see also R \& R Energies v. Mother Earth Indus., Inc., 936 P.2d 1068, 1077 (Utah 1997) (discussing situations where no extrinsic evidence is necessary). This rule and the preceding rule may differ little in practical consequence from a rule that turns interpretation over to a jury once a writing is found to be ambiguous. It is natural, once a writing is found to be ambiguous, to ask the parties what they thought it meant. The issue then becomes one of credibility, which makes it one for the jury.

177. See Nanakuli Paving \& Rock Co. v. Shell Oil Co., 664 F.2d 772, 806 (9th Cir. 1981) (Kennedy, J., concurring) (making this point succinctly in a concurring opinion to one of the more liberal decisions in the area). In Nanakuli, Judge Kennedy wamed:

Our opinion should not be interpreted to permit juries to import price protection or a similarly specific contract term from a concept of good faith that is not based on well-established custom and usage or other objective standards of which the parties had clear notice.... In my view, these are necessary predicates for either theory of the case, namely, interpretation of 
The jury plays an even smaller role in contract construction. It is well-established that the judge decides whether to excuse a contract due to changed circumstances under the doctrines of impracticability, ${ }^{178}$ impossibility, ${ }^{179}$ and frustration of purpose; ${ }^{180}$ whether a stipulated damages clause is unenforceable as a penalty; ${ }^{181}$

the contract based on the course of its performance or a finding that good

faith required the seller to hold the price.

Id. at 806. The majority opinion echoes this in explaining the role of usage in interpretation. See id. at 794-805. It laid down two guidelines: "First, the court must allow a check on usage evidence by demanding that it be sufficiently definite and widespread to prevent unilateral post-hoc revision of contract terms by one party." Id. at 803 . Second usage may only "qualify" the express terms of the agreement, meaning to "cut down" express terms although not to negate them entirely. Id. at 805 . Some cases require that usage be proven by clear and convincing evidence. See Joseph H. Levie, Trade Usage and Custom Under the Common Law and the Uniform Commercial Code, 40 N.Y.U. L. Rev. 1101, 1102 n.5 (1965) (collecting pre-UCC cases).

178. See Opera Co. of Boston Inc. v. Wolf Trap Found. for Performing Arts, 817 F.2d 1094, 1102-03 (4th Cir. 1987) (stating that foreseeability of an event is determined by the judge); T.S.I. Holdings, Inc. v. Jenkins, 924 P.2d 1239, 1248 (Kan. 1996) ("Whether a party should be excused from its obligations under a written agreement because of impracticability of performance is a question of law."); Restatement (Second) of Contracts ch. 11, introductory note, at 309-10 (1979) (stating that the availability of the defense of impracticability is a question to be decided by the court); E. Allan Farnsworth, Contracts $\S 9.6$, at 544 (2d ed. 1990) ("Although these requirements involve questions of fact, courts have sometimes been reluctant to entrust the granting of excuse on this ground [impracticability] to a jury.").

Some cases give the jury a larger role in deciding mutual mistake. See Inland Wetlands and Watercourses Agency v. Landmark Inv. Group, Inc., 590 A.2d 968, 971 (Conn. 1991) ("Whether there has been [a mutual] mistake is a question of fact."). Probably this derives from the large role that subjective understanding plays in the doctrine of mutual mistake. A contract will be voided on grounds of mutual mistake only if the parties shared an understanding about a material fact that was not true. What the jury decides in a mutual mistake case has been cut more finely. See Thompson-Arthur Paving Co. v. Lincoln Battleground Assocs., 382 S.E.2d 817, 822 (N.C. Ct. App. 1989) (stating that whether party assumed the risk of a mistake because he knew or had limited knowledge on the matter is a question for the jury). Davenport Bank and Trust Co. v. State Cent. Bank, 485 N.W.2d 476, 480 (Iowa 1992), holds that whether a party agreed to bear the risk of a mistake is a question of law. See id. at 481 . This is possible because in Iowa the interpretation of a written contract is a question for the court. See id. at 480 . Matters other than the parties' subjective understanding tend to be decided by the judge. See Sunshine v. M. R. Mansfield Realty, Inc., 575 P.2d 847, 848-49 (Colo. 1978) (en banc) (stating and applying the rule that when there is a mutual mistake the determination of the contract's meaning is an issue of law for the judge and one upon which a court of appeals may freely pass).

179. See Sunflower Elec. Coop., Inc. v. Tomlinson Oil Co., 638 P.2d 963, 969 (Kan. Ct. App. 1981) (holding that the availability of the defense of impossibility is a question of law). But see Meuse-Rhine-Ijssel Cattle Breeders v. Y-Tex Corp., 590 P.2d 1306,1312 (Wyo. 1979) ("[T]he issue of impossibility of performance is a question normally most suitable for determination by the trier of fact.").

180. See Mitchell v. Ceazan Tires, Ltd., 153 P.2d 53, 54 (Cal. 1944) ("The excuse of frustration ... is a conclusion of law."); Washington State Hop Producers, Inc. v. Goschie Farms, Inc., 773 P.2d 70, 75 (Wash. 1989) (en banc) ("Application of the doctrine of frustration is a question of law and not a question of fact.").

181. See Liberty Life Ins. Co. v. Thomas B. Hartley Constr. Co., 375 S.E.2d 222, 
and whether a contract violates public policy.12 None of these doctrines take the form of bright-line rules. Indeed some are difficult to put into words. The jury's role under these doctrines is limited to finding specific facts when a decision is seen as turning on specific contested facts. For example, under the doctrine voiding contracts against public policy, the jury may be asked to determine the motive behind the contract when the motive is relevant. ${ }^{183}$ Thus, the jury

223 (Ga. 1989) (holding that the enforceability of liquidated damages clauses is a question of law; in deciding it, however, the trial court must make a "tripartite inquiry" which "requires the resolution of questions of fact"); Aurora Bus. Park Assocs., L.P. v. Michael Albert, Inc., 548 N.W.2d 153, 155 (Iowa 1996) ("Whether a contract provision is a valid liquidated damages clause or an unenforceable penalty is a question of law for the court."); Wasserman's Inc. v. Township of Middletown, 645 A.2d 100, 110 (N.J. 1994) ("Although the question is one of law, it may require resolution of underlying factual issues."); Phillips v. Phillips, 820 S.W.2d 785, 788 (Tex. 1991) (stating that the enforceability of a liquidated damages clause is a question of law that nonetheless requires the resolution of predicate factual issues, such as the amount of actual damages); Highgate Assocs. v. Merryfield, 597 A.2d 1280,1282 (Vt. 1991) (same). Because of the factual nature of the issue, some appellate courts defer to the judgment of the trial judge. See Illingworth v. Bushong, 688 P.2d 379, 390 (Or. 1984) (en banc) (stating that because the reasonableness of liquidated damages is a question of fact, the appellate court should defer to the trial judge's findings on the issue); Reliance Ins. Co. v. Utah Dep't of Transp., 858 P.2d 1363,1367 (Utah 1993) (same); Wassenaar v. Panos, 331 N.W.2d 357, 361 (Wis. 1983) (same).

182. See Missouri, Kan. \& Tex. Ry. Co. v. Harriman, 227 U.S. 657, 672 (1913) (holding that the reasonableness of provisions for shortened claims periods in contract of carriage is a question of law); W.R. Grace \& Co. v. Mouyal, 422 S.E.2d 529,531 (Ga. 1992) (discussing the reasonableness of a restrictive covenant in an employment contract); Stearns v. Williams, 240 P.2d 833, 837 (Idaho 1952) (discussing agreement to give part interest in real estate to a govermment official); Trotter $v$. Nelson, 684 N.E.2d 1150, 1152-55 (Ind. 1997) (discussing validity of alleged referral fee agreement); Straub v. B.M.T., 645 N.E.2d 597, 599 (Ind. 1994) (discussing mother's prenatal promise to release the father from his child-support duties); Brignull v. Albert, 666 A.2d 82, 84 (Me. 1995) (discussing reasonableness of noncompetition covenant); Ploen v. Union Ins. Co., 573 N.W.2d 436, 441-42 (Neb. 1998) (discussing coverage restrictions in a motorist insurance policy); Jewel Box Stores Corp. v. Morrow, 158 S.E.2d 840, 843 (N.C. 1968) (discussing reasonableness of a covenant not to compete); Hargrave v. Canadian Valley Elec. Coop., Inc., 792 P.2d 50, 58-59 (Okla. 1990) (discussing rate discrimination by a public utility); Peyton v. Margiotti, 156 A.2d 865, 868 (Pa. 1959) (discussing validity of a contingent fee agreement made with an attorney to secure release from prison); Durapin, Inc. v. American Prods., Inc., 559 A.2d 1051, 1053 (R.I. 1989) (discussing reasonableness of non-competition covenant); Jasper v. Smith, 540 N.W.2d 399, 403 (S.D. 1995) (discussing the attachment of an attorney's lien to an alimony award); Littlefield $v$. Schaefer, 955 S.W.2d 272, 274 (Tex. 1997) (stating that whether a release is sufficiently conspicuous to be enforceable is a question of law); Travel Masters, Inc. v. Star Tours, Inc., 827 S.W.2d 830, 832 (Tex. 1991) (discussing the reasonableness of a covenant not to compete); Rollins Burdick Hunter of Wis., Inc. v. Hamilton, 304 N.W.2d 752, 756 (Wis. 1981) (stating that the reasonableness of a restrictive covenant is question of law though it is fact-sensitive and not amenable to "per se" rules).

183. See Merchants Nat'l Bank of Mobile v. Cotnam, 34 So. 2d 122, 130 (Ala. 1948) (holding that where the consideration must be inferred, the consideration's legality is a question of fact for the jury); Bell v. Pierson, Morris 29, 32 (Iowa 1839) (holding that jury decides only on the truth of the facts allegedly constituting illegality); First 
decides the factual question whether a contract between lovers was a bargain for sex, which would violate public policy (though I suspect in these cases that judges put the factual question to the jury partly out of their discomfort with the moral issues raised). ${ }^{184}$ Similarly, when a contractor seeks to recover additional expenses, the question whether he had assumed the risk of the overrun by the terms of the contract, therefore barring recovery, may be put to the jury if the answer to that question is not apparent from the agreement itself. ${ }^{185}$

The law of contract construction looks like the photo negative of negligence law. The jury has a say only when an outcome flows from the facts as a matter of rule. Non-rule-based decisions are made by the judge. That this is not thought to intrude on the role of the jury as the fact-finder is attributable to the rules on contract interpretation. Many factual issues, such as the foreseeability of an event, will not turn on credibility, and so need not be put to the jury. Those that might turn on credibility, principally issues about the parties' understanding, often are resolved from objective evidence under the rules on interpretation.

The jury's role in classical contract law most resembles its role in negligence law when it is asked to decide whether there is an impliedin-fact contract. ${ }^{186}$ The question of the existence of an implied-in-fact contract is understood to be highly fact-sensitive and not amenable to rules. ${ }^{1{ }^{17}}$ It is well-established that it is a question for the jury. ${ }^{188}$ But

Nat'l Bank of Lewis v. Strawn, 67 P.2d 589, 592 (Kan. 1937) (holding that whether a note was given to stop prosecution of a criminal charge is a question of fact for the jury); Berg v. Plitt, 12 A.2d 609, 614 (Md. 1940) (holding that the legality of designating one person as a bidder for a group at an auction depends on the group's intent, which is a question of fact for the jury); Cirulli v. Licata, 77 A.2d 288, 290-91 (N.J. Super. Ct. App. Div. 1950) (holding that it is a question for the jury to determine if the motive for making a loan was for a legal purpose); Grover v. Bruere, 9 N.J.L. 319,321 (1827) (holding that whether payment was made to abandon criminal proceedings or to adjust other liabilities is a question of fact for the jury); Vodopest $v$. MacGregor, 913 P.2d 779, 785 (Wash. 1996) (en banc) (holding that whether defendant's conduct occurred in furtherance of a medical research project is a question of fact).

184. See Green v. Richmond, 337 N.E.2d 691, 696 (Mass. 1975) (holding that when the facts surrounding the making of a contract are in dispute, it is a fact question for the jury whether a promise to make a will was in consideration for sexual intercourse); Hill v. Westbrook's Estate, 247 P.2d 19, 21 (Cal. 1952) (en banc) (same); Stewart v. Waterman, 123 A. 524, 526 (Vt. 1924) (same).

185. See Hensel Phelps Const. Co. v. King County, 787 P.2d 58, 61-62 (Wash. Ct. App. 1990) (holding that the question of whether the contractor assumed the risk of the overrun is one for the jury, unless the answer is based on whether it was apparent on the face of the agreement, in which case the question is for the judge).

186. Another jury issue, similar to the breach issue in negligence, is whether a person exercised ordinary care in failing to read a written agreement. See Hanson v. American Nat'l Bank \& Trust Co., 865 S.W.2d 302, 307 (Ky. 1993); Cowart v. Honeycutt, 125 S.E.2d 382, 387 (N.C. 1962) (holding that the question of whether the failure to read a release that was fraudulently induced was one for the jury); Parks $v$. Morris Homes Corp., 141 S.E.2d 129, 132 (S.C. 1965) (same).

187. See Leikvold v. Valley View Community Hosp., 688 P.2d 170, 174 (Ariz. 1984) 
even here the jury is given nothing resembling the normative discretion it has in negligence cases. The question of the existence of an implied-in-fact contract is not put to the jury in the same general terms that the question of reasonableness is put to the jury in negligence. For example, in a claim for payment for services rendered without an express contract, the judge instructs the jury that it can find an obligation only if the defendant requested the services or they were rendered with his consent and it was reasonable for the plaintiff to believe that the defendant would pay for the services. ${ }^{189}$ The jury is not asked whether it would be reasonable or fair for the defendant to pay for what he received.

The character of the instruction flows from the basis of obligation in contract. A person's belief that he was under a moral obligation is not a basis for finding a contract. ${ }^{190}$ The basis of contract is the understanding (actual or apparent) that conduct entails a contractual obligation. ${ }^{191}$ The difference between moral and contractual

(en banc) (holding that the question of whether a policies manual was part of an employment contract is a question of fact for the jury).

188. The most striking cases that endorse this uncontroversial proposition submit to the jury the issue of whether there was an implied-in-fact term protecting an employee from an arbitrary firing based on an employment manual and past practice. See id. at 174; Morriss v. Coleman Co., 738 P.2d 841, 848 (Kan. 1987). Some courts struggle to avoid giving this issue to the jury. It has been held that no reasonable person could find a contract when a manual has a disclaimer, even when the disclaimer is inconspicuous. See Sanderson v. First Sec. Leasing Co., 844 P.2d 303, 306 (Utah 1992); see also Garcia v. Uniwyo Fed. Credit Union, 920 P.2d 642, 645 (Wyo. 1996) (treating the issue as one of interpreting the manual and keeping it from the jury if the manual is not ambiguous on its face). To establish an implied contract by usage or custom, some cases require proof of clear and convincing evidence of a regular practice. See Bailey v. Sewell Coal Co., 437 S.E.2d 448, 451 (W. Va. 1993) (rejecting claim for severance pay on this basis).

189. See Danforth v. Ruotolo, 650 A.2d 1334, 1335 (Me. 1994).

190. For the moment, I put aside the question whether the inquiry regarding implied-in-law contracts is similarly morally obtuse. The short answer is that it is not, but to appreciate that answer and its significance it is useful to consider the general concept of unjust enrichment in restitution and the specific concept of abuse of a confidential relationship.

191. It is tempting to substitute "beliefs about legal obligation" for "beliefs about contractual obligation," but that would not be faithful to contract law. Generally, if people manifest an intention to enter into an agreement of the type that the law enforces-that is, a contract-they are obligated without regard to whether they believed the agreement was legally binding. See Restatement (Second) of Contracts $\$$ 21 (1979) ("Neither real nor apparent intention that a promise be legally binding is essential to the formation of a contract, but a manifestation of intention that a promise shall not affect legal relations may prevent the formation of a contract."). Plainly intention to be legally bound is not sufficient to create a contract. That is the upshot of the abolition of the seal and the rejection of "peppercorn." If you take the Restatement at face value, a shared intent not to be bound does not prevent a contract from arising. But why, then, is a disclaimer effective under the second clause? If an expressed understanding can negate obligation, why does a shared subjective understanding fail to do so?

Cohen v. Cowles Media Co., 457 N.W.2d 199 (Minn. 1990), suggests a more subtle problem in insisting that beliefs about legal obligation are irrelevant. The case holds 
obligations is irrelevant to most implied-in-fact contracts because the conduct gives rise to both sorts of obligation. But this difference can be crucial. It is crucial when unmarried mates end a long-term relationship and one claims a contractual right to assets held in the name of the other. There is a moral obligation to treat one's longtime mate fairly, even in ending a relationship. In most states, however, this belief does not by itself serve as a basis for finding an implied-in-fact contract. ${ }^{292}$ Courts that choose not to throw out such claims entirely on policy grounds (which they treat as a question for the judge), ${ }^{193}$ struggle to say just what is required. A popular formulation requires a finding of an understanding that services would be paid for (a hard claim to make out) or property shared (an easier claim, particularly when the plaintiff contributed money or labor to the acquisition of the property). ${ }^{194}$

People criticize as naïve the view that contract law is simply about enforcing the agreements that people make because contract law supplies terms to fill gaps in agreements and limits the agreements that the state will enforce. That criticism is apt if we look at what judges do in administering contracts. But when we look at what juries do, there is considerable truth in the naïve view. Under classical contract law, the jury makes factual findings to assist in enforcing the agreements people make. I turn now to the question of whether the loosening of contract law through the interjection of standards of fair dealing has altered the picture.

that an agreement between a reporter and his source to keep the identity of the source confidential is not legally binding, although the agreement was a morally binding bargain. See id. at 203. The court reasoned that the parties could not have understood the agreement as legally binding. See id. The case raises the broader question of what contract law's position should be regarding agreements that traditionally the law has not enforced but where a legal obligation is not expressly disclaimed. The early employment manual cases posed the same problem. In an earlier era, courts dismissed these claims because of indefiniteness, inability to prove damages, lack of consideration, or lack of a writing. The erosion of these barriers brings to the fore the question of whether intent to be bound is necessary for the formation of a contract. Cohen has a checkered history. The United States Supreme Court reversed it, reasoning that the Minnesota Supreme Court erred in resting its decision on the First Amendment. See Cohen v. Cowles Media Co., 501 U.S. 663, 672 (1991). On remand, the reporter prevailed. See Cohen v. Cowles Media Co., 479 N.W.2d 387, 388 (Minn. 1992).

192. But see Marvin v. Marvin, 557 P.2d 106, 121 (Cal. 1976) (missing the point when the court held that: "[I]n any event the better approach is to presume ... 'that the parties intended to deal fairly with each other"' (citation omitted)).

193. See Morone v. Morone, 413 N.E.2d 1154, 1155-56 (N.Y. 1980).

194. See Carroll v. Lee, 712 P.2d 923, 927 (Ariz. 1986); In re Estate of Alexander, 445 So. 2d 836, 837-39 (en banc) (Miss. 1984); Beal v. Beal, 577 P.2d 507, $510-11$ (Or. 1978); Watts v. Watts, 405 N.W.2d 303, 314 (Wis. 1987) (pushing the boundary of this approach by finding an implied-in-fact contract upon a tacit understanding of a vague nature that the parties would share the property equally); Shaw v. Smith, 964 P.2d 428, 436 (Wyo. 1998). 


\section{B. Standards of Fair Dealing}

The standards of fair dealing-the most important of these being the standard of good faith and fair dealing - might seem to belie the claim that the jury plays no role in deciding normative issues in contract law. The Restatement (Second) of Contracts expresses the dominant view that the standard of good faith is very much like the reasonableness standard in negligence. The Restatement says that the meaning of good faith cannot be defined by rules because it varies contextually with the touchstone finally being "community standards of decency, fairness or reasonableness."195 While the Restatement does not say whether good faith is an issue for judge or jury, the logical implication given this conception of good faith is that it is an issue for the jury. Several cases draw this conclusion. ${ }^{196}$ Other courts, drawing the same conclusion, reject the doctrine of good faith for the stated reason that it gives the jury too much power. ${ }^{19}$ This same concern, while unstated, may underlie some of the many decisions that shear the doctrine of much of its power. ${ }^{198}$

This part shows that the jury does not play as large a role in administering the standard of good faith as is supposed. I expand the argument to include the doctrines of duress and non-disclosure for they raise a similar issue. This part demonstrates that while the spirit of these doctrines may be captured by a standard of fair dealing, their

195. Restatement (Second) of Contracts $\S 205 \mathrm{cmt}$. a.

196. See Amoco Oil Co. v. Ervin, 908 P.2d 493, 499 (Colo. 1995) (en banc); Sons of Thunder, Inc. v. Borden, Inc., 690 A.2d 575, 584 (N.J. 1997); Brown v. Weis, 871 P.2d 552, 564 (Utah Ct. App. 1994); Carmichael v. Adirondack Bottled Gas Corp., 635 A.2d 1211, 1217 (Vt. 1993); see also John D. Calamari \& Joseph M. Perillo, Contracts $\S 11-38$ (c), at 511 (3d ed. 1987) (drawing the same conclusion); Steven J. Burton, Breach of Contract and the Common Law Duty to Perform in Good Faith, 94 Harv. L. Rev. 369, 370 n.6 (1980) (drawing the same conclusion). But see 3 Corbin, Corbin on Contracts, supra note 166, at $\S 654 \mathrm{~B}$ (stating that while "[g]ood faith always involves questions of fact. ... it often involves questions of law").

197. See English v. Fischer, 660 S.W.2d 521, 522 (Tex. 1983).

198. Some cases insist that the doctrine of good faith may not be used to supplement or to alter the obligations expressed in a contract. Under this view, the doctrine exists only to ensure that parties to a contract performed their obligations in good faith. See, e.g., Comcoa, Inc. v. NEC Tels., Inc., 931 F.2d 655, 665 (10th Cir. 1991) (considering express language and good faith together); Alan's of Allanta, Inc. v. Minolta Corp., 903 F.2d 1414, 1429 (11th Cir. 1990) (rejecting claim that implied covenant was a contract term); Government St. Lumber Co. v. AmSouth Bank, 553 So. $2 \mathrm{~d} 68,73$ (Ala. 1989) (finding that a party cannot be required to surrender a right he possesses in the name of good faith); Gilbert v. El Paso Co., 575 A.2d 1131, 1143 (Del. 1990) (stating that the implied covenant of good faith "cannot override the literal terms of an agreement"); Brehany v. Nordstrom, Inc., 812 P.2d 49, 55 (Utah 1991) (preventing implied covenant of good faith from substantively limiting employer's right to discharge); Badgett v. Security State Bank, 807 P.2d 356, 360 (Wash. 1991) (en banc) (finding that requirement of good faith does not inject substantive terms in the contract); see also Tanner v. Church's Fried Chicken, Inc., 582 So. 2d 449, 452 (Ala. 1991) (refusing to enforce an express good faith clause in a contract on the bizarre reasoning that the duty of good faith is "directive, not remedial"). 
corporeal bodies consist largely of rules. Judges use these rules in determining what is fair dealing. The limited role the jury plays in deciding what is inappropriate conduct under these doctrines can be explained entirely as a product of the procedural difficulty of separating factual and normative issues on a case by case basis. Unlike negligence law, no independent value is placed on popular judgment regarding what is inappropriate conduct.

The claim that the law of duress is shaped around a set of rules that define inappropriate conduct in categorical terms should ruffle few feathers. Unlike good faith, there is as yet no general norm that is thought to encapsulate all of duress. ${ }^{199}$ Dawson proposed such a norm in a justly renowned Article a half century ago when he argued that duress is best understood as protecting against the extraction of excessive gain from the exercise of an imbalance of bargaining power. 200 His re-conceptualization of the doctrine never caught on, though his concept of "economic duress" did. ${ }^{201}$ The heart and soul of the law of duress is in the definition of improper threat. ${ }^{202}$ Most types of improper threats are defined by rules that do not require a

199. See Restatement (Second) of Contracts $\$ 176$ (stating seven rules or standards to define an improper threat).

200. See John P. Dawson, Economic Duress: An Essay in Perspective, 45 Mich. L. Rev. 253, 282-90 (1947).

201. See Totem Marine Tug \& Barge, Inc. v. Alyeska Pipeline Serv. Co., 584 P.2d 15, 23-25 (Alaska 1978) (finding duress where buyer withheld amounts due under contract to coerce seller who was in desperate financial straits to settle for much less).

202. Duress requires an improper threat that leaves the victim no reasonable alternative but to accept the threat-maker's terms. Whether the victim had a reasonable alternative is usually treated as a jury question. See Reiver v. Murdoch \& Walsh, P.A., 625 F. Supp. 998, 1013-14 (D. Del. 1985); Totem Marine Tug \& Barge, 584 P.2d at 22 ("What constitutes a reasonable alternative is a question of fact, depending on the circumstances of each case."); Louisville Title Ins. Co. v. Surety Title \& Guar. Co., 132 Cal. Rptr. 63, 77-78 (Ct. App. 1976) ("The determination of whether there is a reasonable alternative is made by ascertaining as a question of fact whether a reasonably prudent person would follow the alternative course."); Blubaugh v. Turner, 842 P.2d 1072, 1074-75 (Wyo. 1992) ("Whether particular facts are sufficient to constitute economic duress is a question of law.... What constitutes a coercive act or reasonable alternative is a question of fact depending upon the circumstances of each case.").

The old psychological theory of duress lingers on in a few places. See In re Marriage of Baltins, 260 Cal. Rptr. 403, 414 (Ct. App. 1989); Balling v. Finch, 21 Cal. Rptr. 490, 493-94 (Dist. Ct. App. 1962); Willms Trucking Co. v. JW Const. Co., 442 S.E.2d 197, 202 (S.C. Ct. App. 1994). The psychological theory asks whether the victim was bereft of the free exercise of his will power. See Willms Trucking, 442 S.E.2d at 202. Some versions of the psychological theory treat the nature of the threat as irrelevant. See Central Acceptance Corp. v. Nash Bluefield Motor Co., 139 S.E. 654, 656 (W. Va. 1927). Other versions require in addition that the threat be unlawful. The psychological theory has been subjected to scathing criticism, most famously by Holmes and Robert Hale. See Robert Hale, Bargaining, Duress, and Economic Liberty, 43 Colum. L. Rev. 603, 616-18 (1943). A theory of duress that is pitched entirely on the state of mind of the victim makes the issue intensely factual and thus, according to many cases that define duress in purely psychological terms, an issue that is usually for the jury. 
normative judgment at the point of application. Among these are rules that cover a threat to commit a crime or tort, a threat to bring baseless litigation, and a threat to do an act that would inflict a loss on the victim that is grossly disproportionate to the benefit to the threatmaker from doing the act (the last rule covers blackmail).20 While the last rule is moralistic in tone, the only non-factual judgment required in its application is in the determination of whether the balance of harm and benefit is grossly disproportionate. Only a few of the rules that define improper threats call for a normative judgment at the point of application. The most important of these addresses coercive contract modifications: a bad-faith threat to breach a contract is improper. ${ }^{204}$ Another rule defines a threat as improper if the threatmaker obtained his position of power by a prior course of unfair dealing. ${ }^{205}$ Determining whether a threat to breach a contract is in bad faith (not every threat to breach is improper) and whether a prior course of dealing is unfair calls for a normative judgment.

The law of fraudulent non-disclosure is similar in form to the law of duress. There is no general principle defining when disclosure is obligatory. Rather, disclosure is required in several discretely defined circumstances. ${ }^{206}$ No evaluative judgment is necessary in determining when most of these circumstances exist.207 Two of the circumstances in which disclosure is obligatory are defined by open-ended standards that call for a normative judgment at the point of application. I put the discussion of one of these standards - a confidential relationshipoff until later because it is of broader significance. The other openended standard requires disclosure when it reasonably might be expected by the ignorant party. The usual reason for requiring disclosure under this standard is that the ignorant party could not feasibly obtain the information on his own. ${ }^{209}$ It is upon this standard

203. See Philippine Export \& Foreign Loan Guarantee Corp. v. Chuidian, 267 Cal. Rptr. 457, 468 (Ct. App. 1990); Silsbee v. Webber, 50 N.E. 555, 556 (Mass. 1898) (J. Holmes) (involving a threat by an employer to disclose embarrassing information about a young employee to the lad's ill father in order to coerce the mother to pay off the lad's debt).

204. See Totem Marine Tug \& Barge, 584 P.2d at 22.

205. See Andreini v. Hultgren, 860 P.2d 916, 921-22 (Utah 1993).

206. See Restatement (Second) of Contracts $\$ 161$ (1979) (stating four general circumstances when disclosure is required); Restatement (Second) of Torts $\S 551$ (1977) (stating five circumstances where disclosure is required); see also Mattingly v. First Bank of Lincoln, 947 P.2d 66, 70 (Mont. 1997) (stating even more circumstances).

207. These include the duty to disclose that the other party has made an error in interpreting a contract, see Restatement (Second) of Contracts $\S 161(c)$, the duty to correct past assertions that have become untrue, see id. $\$ 161$ (a), the duty to exercise reasonable care in communicating or obtaining the correct information, see Restatement (Second) of Torts $\S 552(1)$, and the duty of a fiduciary to disclose, see id. $\S 552(2)(a)$.

208. See infra part IV.

209. See United Jersey Bank v. Kensey, 704 A.2d 38, 43-44 (N.J. Super. Ct. App. 
and for this reason that sellers and brokers have been required to disclose hidden defects in what they sell, particularly in the sale of residential real estate. ${ }^{210}$

Putting confidential relationships to the side, the common practice under the law of duress and non-disclosure is that the judge decides what is inappropriate conduct under the open-ended standards. Almost universally, the judge decides when disclosure reasonably might be expected by the ignorant party. ${ }^{211}$ As for duress, there are many statements like the following: "[w]hile what constitutes duress is a question of law, whether duress exists in a particular case is a question of fact."'12 This does not require a judge to ground his

Div. 1997) (posing the question as "one of fairness and policy that 'involves identifying, weighing, and balancing several factors-the relationship of the parties, the nature of the attendant risk, the opportunity and ability to exercise care, and the public interest in the proposed solution"" (citations omitted)); Restatement (Second) of Torts $\S 551(2)(\mathrm{e})$ (stating that where disclosure is required because of "the customs of the trade or other objective circumstances, [the other] would reasonably expect a disclosure"); see also Restatement (Second) of Contracts $\$ 161$ (b) (requiring disclosure if "non-disclosure of the fact amounts to a failure to act in good faith and in accordance with reasonable standards of fair dealing").

210. See Hill v. Jones, 725 P.2d 1115, 1118-20 (Ariz. Ct. App. 1986); Reed v. King, 193 Cal. Rptr. 130, 131-32 (Ct. App. 1983); Lynn v. Taylor, 642 P.2d 131, 134 (Kan. Ct. App. 1982); Obde v. Schlemeyer, 353 P.2d 672, 674-75 (Wash. 1960); Ollerman v. O'Rourke Co., 288 N.W.2d 95, 100 (Wisc. 1980). But see Swinton v. Whitinsville Sav. Bank, 42 N.E.2d 808, 808 (Mass. 1942) (finding that when acting at arms length or when there is no fiduciary relationship between the parties then, there is no duty to disclose non-apparent defect).

211. The Second Restatement of Torts states:

Whether there is a duty to the other to disclose the fact in question is always a matter for the determination of the court. If there are disputed facts bearing upon the existence of the duty, as for example the defendant's knowledge of the fact, the other's ignorance of it or his opportunity to ascertain it, the customs of the particular trade, or the defendant's knowledge that the plaintiff reasonably expects him to make the disclosure, they are to be determined by the jury under appropriate instructions as to the existence of the duty.

Restatement (Second) of Torts $§ 551 \mathrm{cmt}$. m. See Frazier v. Southwest Sav. and Loan Ass'n, 653 P.2d 362, 368 (Ariz. Ct. App. 1982) (treating this as an issue for the judge); Mallon Oil Co. v. Bowen/Edwards Assocs., 940 P.2d 1055, 1059 (Colo. Ct. App. 1996) (same); Sinnard v. Roach, 414 N.W.2d 100, 106 (Iowa 1987) (same); Carter LincolnMercury, Inc. v. EMAR Group, Inc., 638 A.2d 1288, 1294 (N.J. 1994) (same); Delgado v. Costello, 580 P.2d 500, 503, (N.M. Ct. App. 1978) (same); First Nat'l Bank \& Trust Co. of Racine v. Notte, 293 N.W.2d 530, 532 (Wis. 1980) (same). Only Alabama (which is out of the mainstream on many issues) seems committed to the view that this is a jury question. See Foremost Ins. Co. v. Parham, 693 So. 2d 409, 422-23 (Ala. 1997) (treating the issue as one for the jury); Ballard v. Lee, 671 So. 2d 1368, 1373-74 (Ala. 1995) (same). But see Union Sec. Life Ins. Co. v. Crocker, 667 So. 2d 688, 692 (Ala. 1995) (treating the issue as one for the judge).

212. Clement v. Buckley Mercantile Co., 137 N.W. 657, 661 (Mich. 1912); see also Meyer v. Guardian Trust Co., 296 F. 789, 792 (8th Cir. 1924) ("What constitutes duress is a matter of law. Whether such duress exists as to a particular transaction is a matter of fact."); Slone v. Purina Mills, Inc., 927 S.W.2d 358, 370 (Mo. Ct. App. 1996) ("Whether the facts alleged are sufficient to support a claim of duress is a question of law for the court."); Cheshire Oil Co., Inc. v. Springfield Realty Corp., 385 A.2d 835, 
decision on a rule that applies beyond the immediate case: if the facts are undisputed he may rule on the facts. ${ }^{213}$ Judges would do better if they remembered this, for occasionally they cloak their decisions in spurious rules, such as the "rule" that a party cannot claim duress when his tight situation is a product of his own circumstances or market conditions and not the conduct of the defendant, ${ }^{214}$ or the "rule" that the assertion of a contractual right can never be duress.215 Only a handful of cases put the questions to the jury, under a general instruction, of whether a threat to breach was in bad faith or whether there was a prior unfair course of dealing to the jury. ${ }^{216}$

839 (N.H. 1978) ("The elements to a finding of duress are questions of law; whether the facts exist to establish those elements in a particular case is an issue for the trial court, and its findings will not be disturbed unless unreasonable."); Production Credit Ass'n of Minot v. Geving, 218 N.W.2d 185, 195 (N.D. 1974) ("[T] he ruling as to what constitutes duress is one of law and not a finding of fact."); Oregon Bank v. Nautilus Crane \& Equip. Corp., 683 P.2d 95, 103 (Or. Ct. App. 1984) ("Whether particular facts are sufficient to constitute a defense of economic duress or business compulsion is a matter of law for the courts, while the question of whether the facts alleged actually exist is a matter for the jury."); Windham v. Alexander, Weston \& Poehner, P.C., 887 S.W.2d 182, 185 (Tex. Civ. App. 1994) ("Although what constitutes duress is a question of law, whether duress exists in a particular situation is generally a question of fact dependent upon all the circumstances surrounding the situation."); Galusha v. Sherman, 81 N.W. 495, 498-99 (Wis. 1900) (discussing elements of duress).

213. Decisions granting summary judgment on duress claims are legion. Sometimes courts characterize the issues of whether there was bad faith or a prior unfair course of dealing as factual in character but then proceed to decide the issue on the ground that it was not in doubt. See, e.g., Evans v. United Air Lines, Inc., 986 F.2d 942, 943-45 (5th Cir. 1993) (rejecting the claim of duress when a seller of package tours relied on an airline for discount tickets, without finalizing the contract, and then was refused a discount when the airline entered into a price war and ticket prices were slashed); First Nat'l Bank and Trust Co. of Vinita v. Kissee, 859 P.2d 502, 503 (Okla. 1993) (deciding case on basis that bad faith was not in doubt); Blubaugh v. Tumer, 842 P.2d 1072, 1074 (Wyo. 1992) (rejecting claim of duress when a fired employee was given a choice between $\$ 31,000$ if he refused to sign release and $\$ 35,000$ with "outplacement" counseling if he would sign release).

214. See Strickland Tower Maintenance, Inc. v. AT\&T Communications, Inc., 128 F.3d 1422, 1426-27 (10th Cir. 1997); Selmer Co. v. Blakeslee-Midwest Co., 704 F.2d 924, 928 (7th Cir. 1983) (quoting Johnson, Drake, \& Piper Inc. v. United States, 531 F.2d 1037, 1042 (Ct. Cl. 1976)) ("The mere stress of business conditions will not constitute duress where the defendant was not responsible for the conditions.").

215. See Teachers Ins. and Annuity Ass'n v. Wometco Enters., 833 F. Supp. 344, 348 (S.D.N.Y. 1993); see also Dawson, supra note 200, at 287 ("No single formula has achieved so wide a circulation in the duress cases as the statement that 'It is not duress to threaten to do what there is a legal right to do.' Certainly no other formula is anything like so misleading. Its vice lies in the half-truth it contains.").

216. In Applied Genetics Int'h, Inc. v. First Affiliated Sec. Inc., 912 F.2d 1238, 1242 (10th Cir. 1990), a company that had tried to go public claimed duress to get out of a release it gave its underwriter. It wanted to sue the undenwriter for breach of a "firm commitment" underwriting agreement, which is a promise by the underwriter to buy any stock that could not be sold to the public. See id. at 1240. The underwriter had refused to go forward with the stock offering at the last moment and then offered to make the company a loan to provide needed capital if the company would sign the release. See id. The underwriter also threatened to inform the Securities Exchange Commission of a violation of securities law in the planned offering. The court held 
The pattern in the law of good faith is similar though less clear because of the misapprehension that there are no rules to go by in this area but instead only a standard of "decency, fairness, or reasonableness."217 Actually, the great majority of good faith cases ground on fairly concrete rules. At its most concrete, good faith means honesty.218 Beyond dishonesty, it is bad faith to feign dissatisfaction to get out of a contract that is conditioned on satisfaction. ${ }^{219}$ More broadly, it is bad faith to exercise a discretionary power under a contract for an improper purpose $e^{220}$ or to fail to fulfill a condition for a strategic reason. ${ }^{21}$ For example, it is bad faith to fire an at-will employee to avoid paying him a promised year-end bonus, ${ }^{22}$ and it is bad faith to neglect to apply for a mortgage in order to get out of a contract that is conditioned on financing. ${ }^{23}$ Even more broadly, bad faith has been defined as the overreaching interpretation of a contract term ${ }^{24}$ or as acting inconsistently with contract-based

whether the underwriter had acted improperly was a question of fact without explaining where it thought the bad faith lay precisely. See id. at 1242 . The implication is that the question of bad faith would be put to the jury in general terms.

In Andreini v. Hultgren, 860 P.2d 916, 917-18 (Utah 1993), a patient sought to void a release of tort claims he had given to his surgeon before an operation on his hand. The surgeon had presented the patient with the release immediately prior to the operation after the patient had been prepared for surgery. See id. at 918. There was some evidence that delay would worsen the operation's prospects for success. See id. at 917 . The court concluded that there was no contract between the patient and the surgeon when the release was presented, but that it was a question of fact whether there had been a prior course of unfair dealing. See id. at 921. Cheshire Oil Co., is similar though the fact-finder (a special master) ultimately rejected the duress claim. 385 A.2d at $837-40$. The plaintiff had jacked up the price of land he offered to defendant from $\$ 5,000$ to $\$ 25,000$ on the day defendant was closing on adjacent land that he had under option. See id. at 838. The court affirmed a finding of no duress while characterizing the issue of whether the plaintiff had acted unfairly as factual. See id. at 840.

In Philippine Export and Foreign Loan Guarantee Corp. v. Chuidian, 267 Cal. Rptr. 457, 460-61 (Ct. App. 1990) a Philippine corporation sought to set aside a settlement of a claim that it alleged it had entered into because the other party threatened to reveal the corporation's connections with Ferdinand Marcos if it did not. The court concluded that this might be duress because of the disproportionality of harm and benefit and held that this issue, as well as the fairness of the resulting exchange, were questions of fact for the jury. See id. at 468.

217. See Restatement (Second) of Contracts $\S 205$, cmt. a (1979).

218. See U.C.C. § 1-201 (19) (1995).

219. See Fursmidt v. Hotel Abbey Holding Corp., 10 A.D.2d 447, $450-51$ (N.Y. App. Div. 1960).

220. See Mark P. Gergen, A Cautionary Tale About Contractual Good Faith in Texas, 72 Tex. L. Rev. 1235, 1265-66 (1994) [hereinafter Gergen, Cautionary].

221. See id. at 1266.

222. See Jordan v. Duff \& Phelps, Inc., 815 F.2d 429, 438 (7th Cir. 1987); see also Gergen, Cautionary, supra note 220, at 1266 n.171 (citing similar cases).

223. See Plaisted v. Fuhr, 367 N.W.2d 541, 545 (Minn. Ct. App. 1985); Gergen, Cautionary, supra note 220, at 1266 n.172 (listing cases).

224. See Robert S. Summers, The General Duty of Good Faith-Its Recognition and Conceptualization, 67 Cornell L. Rev. 810, 813 (1982). 
expectations.225

None of these definitions of good faith ask either judge or jury to evaluate conduct based on their own view (or the community's view) of what is decent, fair, or reasonable.25 Under these definitions, the determination of the meaning of good faith begins with interpretation of the agreement. Who does this depends on the general rules governing contract interpretation, which, as stated previously, give a great deal of power to the judge. Once one identifies the purpose (or purposes) of a discretionary power, condition, or term, then the question becomes whether the party exercising that power, invoking that condition, or asserting that term did so for a reason or in a way that was consistent with that purpose (or those purposes). This is a question of fact for the jury.

For example, in a case where the issue is whether a claim of dissatisfaction with performance was in good faith, the judge will decide whether the test of satisfaction is objective or subjective and so instruct the jury. The jury will then decide whether the claim of dissatisfaction met that test.27 In a case where an at-will employee alleges that his employer fired him to prevent him from collecting a promised bonus, the judge might determine if the promise of a bonus limited the employer's discretion in firing, while the jury will determine the motive for the firing.28

These cases do not exhaust the uses or meaning of good faith. Occasionally the doctrine is used to imply contractual obligations based on trade usage or custom..$^{229}$ Generally, only specific terms that

225. See Burton, supra note 196, at 371-73.

226. Sometimes good faith is used as a performance standard in contracts with open performance terms. See U.C.C. \& 2-306(1) (1995) (stating that under an output or a requirements contract the quantity supplied or demanded must be in good faith). Courts have been maddeningly imprecise in how they formulate the good faith standard in output and requirements contracts. See Mark P. Gergen, The Use of Open Terms In Contract, 92 Colum. L. Rev. 997, 1067-71 (1992) [hereinafter Gergen, Use of Open Terms] (discussing various formulations of this standard). The precise standard is for the judge's determination. See Kansas Baptist Convention v. Mesa Operating Ltd. Partnership, 864 P.2d 204, 210 (Kan. 1993).

227. See Health Maintenance Group v. Rutledge, 459 So. 2d 889, 892 (Ala. Civ. App. 1984) (holding that whether there was good faith in claim of dissatisfaction under a contract with a condition of satisfaction is a question of fact for the jury); Hamlin v. Steward, 622 N.E.2d 535, 540 (Ind. App. 1993) (holding that whether a party acted in a good faith attempt to fulfill a condition is a question for the jury); McKay v. Farmers \& Stockmens Bank, 585 P.2d 325, 327 (N.M. Ct. App. 1978) (holding that whether there was a good faith basis for acceleration of a note is ordinarily a question of fact); McCabe/Marra Co. v. City of Dover, 652 N.E.2d 236, 245 (Ohio Ct. App. 1995) (holding that whether a party acted in a good faith attempt to fulfill a condition is a question for the jury).

228. See Mcllravy v. Kerr-McGee Corp., 119 F.3d 876, 882 (10th Cir. 1998) (affirming summary judgment for employer on claim of bad faith termination by senior employee because plaintiff had not alleged that firing interfered with any promised benefits).

229. See Gergen, Cautionary, supra note 220, at 1268-71 (discussing a number of 
can be proven by objective evidence can be introduced as a matter of trade usage or custom. 230 These restrictions prevent both judge and jury from imposing additional obligations that they believe to be fair or reasonable under the guise of usage or custom.

In a small number of cases, the determination of good faith properly turns on the decision-maker's views about what is fair or reasonable conduct. These cases involve odd circumstances that the parties would not have addressed in contracting, and on which there is no established trade practice. Unfortunately these cases are too few in number to discern a practice regarding whether the judge or jury should decide the meaning of good faith when good faith is not reducible to a rule or derived from the parties' likely understanding. In most cases, the judge decides what good faith means, often by announcing a spurious standard or rule (such as defining bad faith as malice). . $31^{2}$

To appreciate what is at stake in these cases we need to focus on a specific case For the starting point for analysis has to be the recognition that good faith cannot be defined abstractly. Carmichael $v$. Adirondack Bottled Gas Corp. ${ }^{232}$ is the strongest example I know of the view that the jury should decide what good faith means under a general standard. Plaintiff Carmichael was a widow. ${ }^{23}$ Her husband had been a gas distributor for Adirondack. ${ }^{234}$ The Carmichaels had decided to sell the distributorship back to Adirondack, but the parties had not agreed on a price when the husband was killed in a snowmobile accident. ${ }^{235}$ Under the agreement, the distributorship terminated upon his death. ${ }^{236}$ Nevertheless, Adirondack renewed its

these cases).

230. See Nanakuli Paving \& Rock Co. v. Shell Oil Co., 664 F.2d 772, 806 (9th Cir. 1981); supra note 177. The meaning of good faith was resolved by the judge in one of the more controversial good faith cases of the 1980s. See K.M.C. Co. v. Irving Trust Co., 757 F.2d 752, 761 (6th Cir. 1985). In K.M.C., a bank breached its duty of good faith by canceling a line of credit without notice, even though adequate security seemed to exist. See id. at 763. A magistrate decided that good faith required notice unless the decision to dispense with notice was a "reasonable exercise of its discretion." Id. at 759. This put to the jury only the factual question of whether the loan seemed to be insecure at the time. See id. at 761.

231. See Williams v. Jader Fuel Co., 944 F.2d 1388, 1395 (7th Cir. 1991); M/A-Com Sec. Corp. v. Galesi, 904 F.2d 134, 136 (2d Cir. 1990) (quoting Van Valkenburgh, Nooger \& Neville, Inc. v. Hayden Publ'g Co., 281 N.E.2d 142, 145 (N.Y. 1972)); Carter v. Safeway Stores, Inc., 744 P.2d 458, 461 (Ariz. Ct. App. 1987); Ellis v. Chevron U.S.A., Inc., 246 Cal. Rptr. 863, 866-68 (Ct. App. 1988); Edmond's of Fresno v. MacDonald Group, Ltd., 217 Cal. Rptr. 375, 381 (Ct. App. 1985); Carter v. Adler, 291 P.2d 111, 117 (Cal. Dist. Ct. App. 1955); Ranier v. Mount Sterling Nat'l Bank, 812 S.W.2d 154, 156-57 (Ky. 1991); Roli-Blue, Inc. v. 69/70th St. Assocs., 506 N.Y.S.2d 159, 161 (App. Div. 1986).

232. 635 A.2d 1211 (Vt. 1993).

233. See id. at 1213.

234. See id.

235. See id.

236. See id. 
buyout offer after the husband's death and indicated that it was not opposed to the widow keeping the distributorship. 23 Widow Carmichael rejected the renewed offer as too low and began to negotiate with another buyer. 238 Adirondack moved preemptively and without warning, cutting off supplies and closing the business. ${ }^{29}$ The plaintiff found a buyer for the equipment at a price slightly below that offered by Adirondack for the entire distributorship. $2 * 0$ She then turned the company's records, including the customer list, over to Adirondack at their insistence.241 The issue of whether Adirondack had acted in bad faith was submitted to the jury by the trial judge under an instruction detailing what Adirondack's duties were under the circumstances. ${ }^{242}$

Rather than analyzing this instruction in detail (there were doubtful elements), the Vermont Supreme Court held that the trial judge should have put the issue to the jury under a general instruction.2.3 The court reasoned that good faith could be defined only by the general principle that "each party promises not to do anything to undermine or destroy the other's rights to receive the benefits of the agreement."244 It added that the highly fact-specific nature of the issue made it "particularly well-suited for juries to decide" under an instruction that has "few precise analytical elements."2as

Carmichael is a compelling case because of the combination of several unusual facts. These include the accidental death of the plaintiff's husband at a young age, the initial response of the company to his death that suggested it did not care who ran the franchise, the company's abrupt and punitive response to the plaintiff's rejection of its offer, and the pressure the company applied to obtain the intangible assets of the business without paying the plaintiff. Change

237. See id

238. See id.

239. See id.

240. See id.

241. See id. at 1214.

242 See id. at 1216-17. The trial judge's instruction was:

While the contracts between the parties provided that they terminated upon the death of Philip Carmichael, Adirondack was under a duty to treat [p]laintiffs fairly and in good faith. Adirondack had a duty to advise [p]laintiffs whether it would agree to enter into a new contract with them or to allow [p]laintiffs a reasonable opportunity to find a buyer for the distributorship or to decide to sell their interest in the distributorship to Adirondack.

Id. at 1217.

243. See Carmichael, 635 A.2d at 1218.

244. Id at 1216. For a similar instruction, see Sons of Thunder, Inc v. Borden, Inc, 690 A.2d 575, 585-86 (N.J. 1997) (instructing the jury to answer the question: did the defendants "observe reasonable commercial practices of fair dealing. ... [and] refrain from doing anything that would destroy or injure the other party's right to receive the fruits of the contract").

245. Id at 1217. 
any one of these facts ${ }^{246}$ and one's opinion about the fairness of Adirondack's conduct might well change. A good way to test the court's assertion that the question of what is inappropriate conduct in this circumstance is "particularly well-suited for juries to decide" under a general standard is to ask whether the issue of good faith ought to go to the jury had Adirondack forced the widow to take its original offer by consistently insisting that the distributorship terminated at her husband's death. My guess is that few judges would have submitted the issue of good faith to the jury on these facts though people might well disagree about the reasonableness of Adirondack's conduct. ${ }^{247}$

There is no right answer to the question: how should the trial judge have put the plaintiff's bad faith claim to the jury? None of the easy answers are satisfactory. One unsatisfactory answer is to avoid the problem entirely by rejecting the doctrine of good faith or shearing it of much of its power, as some courts have done.248 Another unsatisfactory answer is to pretend, as the Carmichael court did, that there is nothing unusual in giving the jury the power to add obligations to a contract under a general standard of fairness. ${ }^{249}$ The trial judge's solution to the problem is neither easy nor satisfactory. The trial judge tried to spell out precisely what good faith meant under the circumstances of the case but further confused the issue. 250 This may explain why the Vermont Supreme Court grounded its decision upon a general standard. If the court defined good faith specifically, the trial court would have had to retry the case under the new rule.

If we put ourselves in the position of the trial judge but with the

246. For example, assume that Adirondack acted in a way that showed that it thought the husband's death was a material change, or assume that the intangible assets Adirondack acquired for nothing were clearly worthless.

247. For instance, Zapatha v. Dairy Mart, Inc., 408 N.E.2d 1370, 1380 (Mass. 1980), rejected various contract and tort claims brought upon a franchise termination, including a claim of breach of the duty of good faith and fair dealing. The court stressed that the franchisee did not show that it had made any investment that the franchisor captured by terminating the agreement. See id. at 1377.

248. See English v. Fischer, 660 S.W.2d 521, 522 (Tex. 1983); supra note 198 and accompanying text (listing relevant cases).

249. See Carmichael, 635 A.2d at 1216-17.

250. See supra note 233 and accompanying text. One flaw in the instruction is that it is inartfully drafted. The trial judge suggested three possible actions that Adirondack might take to satisfy the obligation of good faith in the disjunctive: (1) tell Carmichael whether Adirondack would allow her to continue in the business; (2) allow her to sell the business; or (3) buy the business itself. See Carmichael, 635 A.2d at 1217 . Read literally, this instruction required only that Adirondack have told Carmichael that she could not continue. Although Adirondack did not do so promptly it could argue that Carmichael suffered no harm from the delay. A second flaw is that the instruction can be read as imposing a duty on a franchisor to allow a franchise to recoup the value of its investment upon termination by sale to a third party or to the franchisor. This is novel. 
luxury of time to reflect on the meaning of good faith, it might be possible to craft an ideal jury instruction or a set of special issues the jury should consider. To my mind, the key factual issues go to the weight of Adirondack's interest in enforcing the termination-on-death clause and the intangible value of the business that Adirondack destroyed or captured. This disregards, however, the reasons for putting the issue of good faith to a jury under a general standard. To demand that a trial judge make a precise determination of what constitutes inappropriate conduct, in a situation where that issue is in great doubt, burdens both counsel and the trial judge, and increases the prospect of an error necessitating a retrial. The ultimate effect is to increase the cost of vindicating the principle of good faith.

You might think this is a good thing if you are troubled by the uncertainty created by the principle of good faith. On the other hand, if you believe that it ought to be easier to vindicate novel good faith claims, but you also believe that the definition of good faith should not be determined by the jury, there are two solutions. One is to redefine the relationship between trial judges and appellate judges. Appellate judges could defer to a trial judge's resolution of the question of what constitutes bad faith. This would be a significant change in the law. Currently, appellate courts do not defer to trial courts on non-factual issues. ${ }^{251}$ Leon Green saw the essential point here years ago. Appellate judges must cede power to trial judges if we want the law to be flexible while not yielding too much power to the jury. ${ }^{22}$ The other solution is to take factual issues from the jury. Appellate judges do defer to a trial judge's resolution of a mixed issue of law and fact.253 But this may be impermissible when a claim of bad faith turns on credibility, as they often do.

\section{ECONOMIC TORTS AND RESTITUTION}

It is not surprising that the jury usually plays a small role in deciding what is inappropriate conduct under contract law doctrines such as good faith. Traditionally, the jury has had little say on obligation in contract law. The marginalization of the jury in contract law is facilitated by rules of interpretation that give priority to writings and other objective evidence. These rules tend to eliminate factual

251. I say this with trepidation because I do not teach procedure. Two colleagues who do, Charles Alan Wright and Patrick Woolley, tell me they are unaware of any principle requiring that appellate judges defer to a trial judge's choice of instructions. Appellate courts do defer to decisions by a trial judge on issues of both fact and law in matters that are peripheral to a trial, such as decisions regarding discovery abuse.

252. See Green, Judge and Jury, supra note 67, at 393-94 ("Instead of a more or less preliminary trial and a serious appeal, there should probably be a more serious trial and an informal checking up of the trial court's work...."). Green attributed the seizure of power by appellate courts to "the unhealthy ascendancy that the jury had obtained over the trial judges." Id. at 380.

253. See Jeffs v. Stubbs, 970 P.2d 1234, 1244-46 (Utah 1998). 
disputes, particularly disputes that turn on the credibility of witnesses, and make it possible for judges to administer standards without having to submit factual issues to the jury.

I now turn to tort doctrines that protect economic interests, along with the law of restitution (the doctrines of duress and non-disclosure, examined previously, exist in both contract and restitution), to see what role the jury plays in these areas. I take issue with the view espoused in the Restatement (Second) of Torts that the jury determines what is improper interference. ${ }^{254}$ I argue that the concept of improper interference is similar to the general principle of unjust enrichment. Both concepts are non-categorical principles defining blameworthy conduct or obligation in bodies of law that are otherwise composed of rules that define blameworthy conduct or obligation in categorical terms. Understanding these concepts leads naturally to the conclusion that judges must decide their meaning in the first instance. ${ }^{255}$

Most economic torts have categorical terms. No general tort exists for negligent or unreasonable infliction of economic loss. Fraud is an example of a categorical tort. It deals with a subset of lies, those that induce others to act in a way that harms themselves or enriches the liar. Defamation in its modern form deals with another subset of lies, those that injure reputation. The issues put to the jury under these doctrines are factual, such as: "did the defendant lie?" and "did his lie have an effect that the law will remedy?" Rules that require a plaintiff to prove a lie by clear and convincing evidence enable the judge to limit the jury's discretion in fact-finding. ${ }^{256}$ Rules prohibiting

254. See Restatement (Second) of Torts $\$ 767 \mathrm{cmt} .1$ (1977).

255. The implications of my position have already been discussed in the context of the standards of fair dealing. See supra notes 252-53 and accompanying text. To require the trial judge to specify what circumstances would render interference improper or enrichment unjust in a case where the normative issue is in grave doubt burdens counsel and the trial judge, and increases the prospect of error necessitating retrial. This makes it difficult to vindicate novel claims. If you want to ease this burden but are committed to having the judge resolve the normative issue of what is improper or unjust, then you have two choices. You can let the trial judge decide the normative issue and factual issues together in a general ruling, or you can ask appellate judges to defer to the trial judge's instruction.

256. Many states impose a standard of clear and convincing evidence or substantial evidence for proof of fraud. See Europlast, Ltd. v. Oak Switch Sys., Inc., 10 F.3d 1266, 1272 (7th Cir. 1993) (applying Illinois law); Weisman v. Kaspar, 661 A.2d 530, 537 (Conn. 1995); Smith v. King, 597 P.2d 217, 220 (Idaho 1979); Modern Air Conditioning, Inc. v. Cinderella Homes, Inc., 596 P.2d 816, 824 (Kan. 1979); Eidson v. Reproductive Health Servs., 863 S.W.2d 621, 626 (Mo. Ct. App. 1993); Sauter v. St. Michael's College, 374 P.2d 134, 138 (N.M. 1962); Tice v. Tice, 672 P.2d 1168, 1171 (Okla. 1983); Pittsburgh Nat'l Bank v. Larson, 507 A.2d 867, 869 (Pa. Super. Ct. 1986). In Arkansas, a clear and convincing evidence standard applies in an action for deceit only if "alteration of a solemn writing" is involved, meaning when a party seeks reformation of the contract in equity. Nicholson v. Century 21, Ivy Realty, Inc., 818 S.W.2d 254, 257 (Ark. 1991); see Grendell v. Kiehl, 723 S.W.2d 830, 831 (Ark. 1987); see also Clay v. Brand, 365 S.W.2d 256, 260 (Ark. 1963) (suggesting that the higher 
the inference of a lie from certain commonplace events (for example, the rule that fraudulent intent in making a promise cannot be inferred from breach) ${ }^{25}$ further hem in the discretion of judge and jury. Through such rules, the law tries to prevent the values of the jury from biasing factual findings.

Sometimes these categorically defined torts have particular elements that require a normative judgment at the point of application. Typically, these normative issues are decided by the judge. For example, in a defamation case, the judge determines whether a communication carries a defamatory meaningzs and whether a privilege exists. ${ }^{259}$ In disparagement, the judge determines whether the plaintiff's interest deserves protection and whether the circumstances of a case give rise to a privilege. ${ }^{260}$ In negligent misrepresentation, the judge determines what circumstances create privity. ${ }^{261}$ If these categorically defined torts described the entire field of economic torts, then we could accurately say that it is judges who define the morality of the marketplace in tort as well as in contract. They do not, however, and therefore, further inquiry is necessary.

\section{A. Improper Interference}

Interference with contract and business relations is the catchall economic tort. ${ }^{262}$ The prima facie interference case is no more than a

standard might be applied if alleged misrepresentation is inconsistent with a specific term of the contract). Some cases refuse or fail to apply a high standard. See International Telecomms. Exch. Corp. v. MCI Telecomms. Corp., 892 F. Supp. 1520, 1542 (N.D. Ga. 1995) (applying Georgia law); V.I.P. Homes, Inc. v. Weader, 454 S.E.2d 548, 550 (Ga. Ct. App. 1995); Ciampi v. Ogden Chrysler Plymouth, Inc. 634 N.E.2d 448, 455 (IIl. App. Ct. 1994); Furr v. Thomas, 817 P.2d 1268, 1271 (Okla. 1991).

257. See Turner v. Biscoe, 171 S.W.2d 118, 119 (Tex. Comm'n App. 1943) (judgm't adopted). A variation on this rule is found in the law of defamation. Malice, which defeats the privilege of a supervisor to defame an employee, cannot be inferred from the falsity of a statement. See Davis v. Hearst, 116 P. 530, 538 (Cal. 1911); see also Gergen, Grudging Defense, supra note 96, at 1719-26 (collecting authority on the point and exploring the non-constitutional roots of the clear and convincing evidence standard in defamation).

258. See Restatement (Second) of Torts $\S 614(1)$ (1977).

259. See id. $\S 619 ; 2$ Fowler V. Harper et al., The Law of Torts $\S 5.29$ (2d ed. 1986).

260. See Restatement (Second) of Torts $\S 652(1)(b),(e)$.

261. See A.T. Kearney, Inc. v. IBM Corp., 73 F.3d 238, 241 (9th Cir. 1995) (citing Oregon law and providing an excellent review of the Oregon cases); Brown v. North Cent. F.S., Inc., 173 F.R.D. 658, 672 (N.D. Iowa 1997) ("The court, not the jury, decides whether defendants were 'in the business of supplying information' as a matter of law, in light of the facts, because the defendants' duty is always a matter for the court to decide."); Eddy v. Sharp, 245 Cal. Rptr. 211, 213 (Ct. App. 1988); Barrie v. V.P. Exterminators, Inc., 625 So. 2 d 1007, 1015 (La. 1993). Some cases interject a step to preserve an issue for the jury. The judge decides on what facts he would find a duty and then the jury decides if those facts exist. See Lindstrand v. Transamerica Title Ins. Co., 874 P.2d 82 (Or. App. 1994).

262. See generally Restatement (Second) of Torts $\$ \S 766,766 \mathrm{~A}, 766 \mathrm{~B}$ (describing the torts of intentional interference with performance of contract by a third person, 
knowing infliction of a fairly concrete economic loss (how concrete the loss must be is a function of how relations or prospective contracts that are protected from interference are defined). The tort is limited by the requirement that the defendant's conduct be "improper." 263 There are some settled rules regarding what is proper. For example, it is proper to compete for business that is not secured by contract. ${ }^{24} \mathrm{It}$ is also proper for an agent to advise his principal to breach a contract so long as he has no personal interest in the matter. ${ }^{265}$ Such rules are few, however, and they leave many issues unsettled.

The Restatement (Second) of Torts takes the position that in cases where there is no settled rule, the issue of impropriety is fact-intensive and turns on a variety of factors, including the nature of the actor's conduct, his motives, his action's proximity to the harm, and the parties' relationship.266 Policy concerns are relevant and so too are "generally accepted standards of common morality"267 or "[r]ecognized standards of business ethics and business customs and practices ... [and] concepts of fair play ...."26s Because of the openended nature of the tort, plaintiffs often use interference claims to challenge arguably unethical economic conduct that falls outside of the more categorical economic torts. ${ }^{269}$ This is precisely the function the tort was meant to serve. ${ }^{270}$ The interference tort descends from Holmes's and Pollock's work in the late nineteenth century. Holmes and Pollock argued that the existing torts did not define all wrongs

intentional interference with another's performance of his own contract, and intentional interference with prospective contractual relation).

263. Id. $\$ 766 \mathrm{~B} \mathrm{cmt.} \mathrm{a.}$

264. See id. $\S 768 \mathrm{cmt}$. b (describing the privilege to compete with others in business).

265. See id. $\$ 770$ (describing when an actor, responsible for the welfare of another, would be liable for improper interference).

266. See id. \& 767(a), (b), (f), (g).

267. Association Group Life, Inc. v. Catholic War Veterans, 293 A.2d 408, 415 (N.J. Super. Ct. App. Div. 1971) (citation omitted).

268. Restatement (Second) of Torts $\$ 767 \mathrm{cmt}$. j.

269. See Woody v. Tamer, 405 N.W.2d 213, 218 (Mich. Ct. App. 1987). In Woody, the plaintiff owned a country club subject to a bank mortgage. See id. at 214 . He sold the club to a group of buyers taking back a non-recourse note while remaining liable on the bank mortgage. See id. After several years the buyers ceased payment on the note, forcing Woody to default on the mortgage. See id. at 215 . Threatened with foreclosure by the bank, Woody gave up his interest in the club. See id. The bank stepped into his shoes on the non-recourse note letting the buyers retain the club. See $i d$. Woody claimed a conspiracy between the bank and the buyers to squeeze him out of the club. See id. He sued the bank for interfering with his contract with the buyers and the buyers for interfering with his ability to pay the bank mortgage. See id. The interference claim against the buyers got around the non-recourse provision of their note. See $i d$. at 217. The interference claim against the bank was analogous to a claim that the bank breached its duty of good faith and fair dealing under its contract with him (the mortgagee) by acting to hinder his performance, but the tort claim opened the door to punitive damages. See id. at 218-19. For my views on how the case should have come out, see Gergen, Tortious Interference, supra note 7, at 1226-31.

270. See Gergen, Tortious Interference, supra note 7, at 1200-18. 
that could be remedied in tort and they proposed the catchall principle of prima facie tort, which held that the intentional infliction of harm was prima facie wrong unless the injurer could justify his action. ${ }^{271}$

The Restatement (Second) of Torts states that the question of the impropriety of interference should be determined by the jury in a case where there is no settled rule regarding the conduct in question and where reasonable people might differ on the issue..$^{2 m}$ This statement is in a comment added in a late draft. ${ }^{273}$ The statement has been influential despite its offhand character. A number of courts have followed it. ${ }^{274}$ Prior cases tended to go in the other direction. ${ }^{275}$

271. See id. at 1206-09.

272 See Restatement (Second) of Torts $\$ 767, \mathrm{cmt} .1$.

273. See Restatement (Second) of Torts cmt. k (Council Draft No. 41, 1977).

274. See Fineman v. Armstrong World Indus., 980 F.2d 171, 211 (3d Cir. 1992) (holding the issue of propriety to be for the jury); Union Sav. Am. Life Ins. Co. v. North Cent. Life Ins. Co., 813 F. Supp. 481, 492 (S.D. Miss. 1993) (same); Association Group Life, Inc. v. Catholic War Veterans, 293 A.2d 408, 415-16 (N.J. Super. Ct. App. Div. 1971) (same); American Marble Corp. v. Crawford, 351 S.E.2d 848, 850 (N.C. Ct. App. 1987) (same); Uptown Heights Assocs. v. Seafirst Corp., 873 P.2d 438, 443 (Or. Ct. App. 1994) (same); Aylett v. Universal Frozen Foods Co., 861 P.2d 375, 379-80 (Or. Ct. App. 1993) (same). Occasional modern cases take the issue of propriety out of the hands of the jury even though the case does not fall under an established privilege. See, e.g., Midland Am. Sales-Weintraub, Inc. v. Osram Sylvania, Inc., 874 F. Supp. 164, 167 (N.D. Ohio 1995) (holding that under Ohio law "while a resolution of each of the factors outlined in the Restatement may require some factual inquiry, the ultimate question of whether an interference is improper and can, thus, support a claim for intentional interference is a question of law"); Maynard v. Caballero, 752 S.W.2d 719, 721 (Tex. App. 1988) (holding that attorney's advice regarding trial strategy to counsel of co-defendant of his client is privileged as a matter of law).

275. In the early cases the court decided the difficult policy questions that go into determining whether conduct is privileged, while the jury decided whether the facts brought the case within the privilege. See 84 A.L.R. 81 (1933) (discussing three early cases that are considered authority for giving the issue of justification to a jury). In the first case, Berry v. Donovan, 74 N.E. 603 (Mass. 1905), the issue was whether a union tortiously interfered with the plaintiff's position as an at-will employee when it induced the employer to fire in order to preserve an all-union shop. See id. at 604 . The court recognized that the central issue in the case was one of policy-did the privilege of competition extend to efforts by labor to preserve a union shop in order to better compete with their employer-and the court decided that question without even suggesting that it might present a jury issue. See id. at 605. In a second case, Order of Railway Conducters v. Jones, 239 P. 882 (Colo. 1925), the court resolved the policy question - that a union may induce an employer to fire a worker to preserve its seniority rules if the worker consented to obey those rules-and left for the jury the factual question whether the worker had consented to the union rules. See id. at 883. In the third case, Carnes v. St. Paul Union Stockyards Co., 205 N.W. 630 (Minn. 1925), the court resolved the policy question-that a stockyard association may bar from entry a person it thought engaged in unethical practices that would bring the industry into disrepute-and left for the jury the factual question whether that was the defendants' true reason for barring the plaintiff. See id. at 632. For a clear early statement that the issue of justification is for the judge, see Conrad v. Schmitz, 3 N.E.2d 868, 869 (N.Y. 1936) (Finch, J., dissenting) ("It is said that whether there is justification sufficient to warrant the courts in protecting the rights of the plaintiff rests upon the individual opinion of the judges as to what constitutes just cause, 
The position of the Restatement is untenable. Two arguments are made in favor of putting the issue of impropriety to the jury. One argument is by analogy to the issue of reasonableness in negligence. ${ }^{276}$ The other is the statement that it is good "to obtain [the jury's] common feel for the state of community mores and for the manner in which they would operate upon the facts in question."2m The analogy to negligence law is not persuasive for we could as well analogize to contract law where, as we have seen, the jury has almost no say regarding what is inappropriate conduct even when that decision is made on an ad hoc basis. ${ }^{278}$ The analogy to contract law also calls into question the assumption that it is good to give the people a voice. If this is an unalloyed good, then why are the people given so little say on normative issues in contract law? If we ask which is the better analogy - to contract law or negligence law-then contract law wins hands down because the economic interests at stake in interference cases are chiefly protected by contract law and not protected at all by negligence law.

Additionally, the proposition does not sit well with the structure of tort law. Were the proposition true, the interference tort would swallow other more categorically defined torts, almost all of which protect economic interests from knowing injury. It would become a question for the jury whether conduct that falls on the boundaries of these other torts is tortious. Consider the tort of "injurious falsehood," or what Fowler Harper and his co-authors describe as "nondefamatory, nondisparaging misrepresentations to third persons."279 For example, the defendant tells the plaintiff's customers that the plaintiff does not have the capacity to serve them. The American Law Institute struggled with defining the boundaries of this tort, ultimately adopting a compromise that held liable a defendant who knew of the falsity of his representation while taking no position on the liability of a defendant who spoke with reckless disregard for the truth out of malice or a desire to harm the plaintiff. 280 Almost all injurious falsehood cases also are cases of tortious interference..$^{281}$ If the jury decides what is improper interference in a doubtful case, then the question over which the Institute struggled regarding the impropriety of speaking in a way that the speaker knows will harm the economic interests of another with reckless disregard for the truth

sufficient justification or legal justification." (quotation omitted)).

276. See Restatement (Second) of Torts $\$ 767 \mathrm{cmt}$. 1 .

277. Id.

278. See supra part III.

279. Harper et al., supra note $259, \S 6.4$.

280. See Restatement (Second) of Torts $\S 623 \mathrm{~A}$.

281. For an example of an injurious falsehood claim packaged as an interference claim, see Comstock Silversmiths, Inc. v. Carey, 894 S.W.2d 56 (Tex. App. 1995) (holding defendant liable for tortious interference where it falsely told plaintiff's customers that the plaintiff was dying). 
would be for the jury to decide.

The same point can be made using the law of unfair trade practices. This body of law is composed largely of categorically defined wrongs having to do with passing off a product as someone else's, and other forms of misappropriation of intangible property. ${ }^{202}$ Several courts that have considered the issue have said that these categorical wrongs do not exhaust the concept of unfair practices and that other forms of commercial misconduct can be brought within the tort if concerns of policy or fairness warrant. ${ }^{233}$ The judge decides what may be an unfair practice. ${ }^{284}$ Novel claims of unfair trade practice almost always can be formulated as interference claims because it is difficult to imagine an unfair trade practice that does not involve the knowing infliction of an

282. See Restatement (Third) of Unfair Competition $\S 1$ (a) cmt. $\mathrm{g}$ (1993) (describing these as "[c]ertain recurring patterns of objectionable practices [that] form the basis of the traditional categories of liability ... these specific forms of unfair competition do not fully exhaust the scope of statutory or common law liability for unfair methods of competition, and subsection (a) therefore includes a residual category encompassing other business practices determined to be unfair.").

283. Some cases find unfair practices that do not quite fit within the established categories. See American Airlines v. Christensen, 967 F.2d 410, 414 (10th Cir. 1992) (finding it to be an unfair practice to purchase frequent flier awards and resell them in violation of the award-holder's contract with airline); Barquis v. Merchants Collection Ass'n, 496 P.2d 817, 839-40 (Cal. 1972) (finding it to be an unfair practice to file debt collection actions in improper and inconvenient venues); Twin Falls Farm \& City Distrib. v. D \& B Supply Co., 528 P.2d 1286, 1294 (Idaho 1974) (finding it to be an unfair practice to destroy competitor's sign stating that business had moved to new Iocation); see also Curtis-Universal, Inc. v. Sheboygan E.M.S., Inc., 43 F.3d 1119, 1124 (7th Cir. 1994) (accepting an expansive definition of unfair competition in holding that an insurer had a duty to defend a claim under a policy that provided for a defense of claims regarding "advertising injury").

On the ineffable character of the tort, see Restatement (Third) of Unfair Competition section 1 comment $g$ which states that:

It is impossible to state a definitive test for determining which methods of competition will be deemed unfair in addition to those included in the categories of conduct described in the preceding Comments. Courts continue to evaluate competitive practices against generalized standards of fairness and social utility. Judicial formulations have broadly appealed to principles of honesty and fair dealing, rules of fair play and good conscience, and the morality of the marketplace.

Id; see also J. Thomas McCarthy, McCarthy on Trademarks and Unfair Competition $\S \S 1: 8-1: 11$ (1996) (collecting many statements along this line).

284. This is made explicit when the standard is defined as practices that "shock judicial sensibilities." Margarete Steiff, Inc. v. Bing, 215 F. 204, 206 (S.D.N.Y. 1914); see also McCarthy, supra note 283 , $\$ 1: 9$ n.5 (listing many of these cases). One way the issue is preserved for the judge conceptually is to characterize unfair competition "s'not [as] a tort with specific elements,' but rather, [as] ... 'a general category of torts which courts recognize for the protection of commercial interests'.... [Thus, to remain viable, a common law unfair competition claim 'must identify the underlying tort which is the basis for [the claim]."' LensCrafters, Inc. v. Vision World, Inc., 943 F. Supp. 1481, 1490 (D. Minn. 1996) (quoting Zimmerman Group v. Fairmont Foods, 882 F. Supp. 892, 895 (D. Minn. 1994)). For a case in which an unusual claim of unfair competition is put to the jury under a general instruction, see Trimed, Inc v. Sherwood Medical Co., 977 F.2d 885, 889-91 (4th Cir. 1992) (considering a claim of wrongful termination of a distributorship). 
economic harm on the plaintiff. If the proposition in the Restatement is true, then whether a tort has been committed in these cases is a question for the jury.

\section{B. Unjust Enrichment}

The picture in restitution is murkier in detail but clearer on the main point. The picture is murky because the content and structure of the law of restitution are unsettled. Sometimes restitution operates as a remedy for a wrong. ${ }^{285}$ Most of the wrongs in restitution are also torts. Fraud is an example of conduct that is considered wrongful that can be remedied either by restitution or tort compensatory damages. 286 A few wrongs only may be remedied in restitution. Duress generally is treated as a basis for restitution but not tort compensatory damages. ${ }^{287}$ Historically, breach of fiduciary duty was a basis for restitution but not for tort compensatory damages, 288 though it has become commonplace to treat it as a tort.289 I will argue in the next part that abuse of a confidential relationship ought to be remedied only in restitution. .20 Abuse of confidential relationship to the side, these wrongs are defined in categorical terms that do not ask for a normative judgment about what is inappropriate conduct at the point of application (fraud is like this).291 Or, when they define inappropriate conduct in open-ended terms that do ask for a normative judgment at the point of application, the judge decides what conduct is inappropriate. We have seen that the law of duress ${ }^{292}$ and the law of non-disclosure ${ }^{293}$ are of this character.

285. It is commonplace to divide the law of restitution into multiple parts, one of which is restitution for wrongs. See Restatement of the Law of Restitution: Quasi Contracts and Constructive Trusts $\S \S 3,121-28$ (1936); Peter Birks, An Introduction to the Law of Restitution, chs. 4 \& 10 (1985) [hereinafter Birks, Introduction] (separating restitution to rectify enrichment at the plaintiff's expense from restitution for wrongs).

286. See Restatement of the Law of Restitution $\S \S 28,55$ (considering mistake of fact and mistake of law induced by misrepresentation).

287. See Douglas Laycock, The Scope and Significance of Restitution, 67 Tex. L. Rev. 1277, 1284 (1989) (mentioning duress as the "leading example" of a case where "defendant may enrich himself by means that we condemn as unjust but for which we would not impose tort liability in the absence of enrichment"); see also Cimarron Pipeline Constr., Inc. v. United States Fidelity \& Guar. Ins. Co., 848 P.2d 1161, 1165 (Okla. 1993) (holding that economic duress is not a tort).

288. See In re Evangelist, 760 F.2d 27, 29-31 (1st Cir. 1985); Kann v. Kann, 690 A.2d 509, 518-20 (Md. 1997).

289. See Restatement (Second) of Torts $\S 874 \mathrm{cmts}$. b, c (1977). Some cases characterize breach of fiduciary duty as an intentional tort. See, e.g., Klemme v. Best, 941 S.W.2d 493, 497 (Mo. 1997) (en banc) (comparing attorney malpractice and breach of fiduciary duty, which is defined as constructive fraud).

290. See infra part V.

291. See supra note 152 and accompanying text.

292. See supra notes 200-06 and accompanying text.

293. See supra notes 207-09 and accompanying text. 
Restitution can also operate as a basis for obligation in circumstances where the obligor did nothing that could be considered wrongful. ${ }^{294}$ The jury plays a small role in deciding obligation here too. ${ }^{295}$ We have already seen that the jury plays a small role in administering contract law doctrines that lay a basis for a restitution claim by invalidating a contract. 206 The same is true of the doctrines in restitution that lay a basis for undoing transfers in non-contractual settings. Even when the law asks for a value judgment at the point of application, the judge makes that value judgment.

For example, a gift can be undone if it was induced by a mistake about the donee's identity or some other "basic fact." Restatement of Restitution takes the position that a basic fact cannot be defined in the abstract, ${ }^{208}$ implying that the issue must be decided

294. See, e.g., Lamkin v. Hill, 419 A.2d 1077, 1080 (N.H. 1980) ("[I]t might be assumed that restitution is appropriate only where the defendant is initially a wrongdoer. This is not quite correct.... [A] constructive trust arises where the title to property is acquired through a mistake." (citations omitted)). But see Davidson v. Davidson, 667 So. 2d 616, 620-21 (Miss. 1995) (holding that restitution will lie only if the defendant has committed a wrong or abused a confidence). The Davidson case is an interesting spin-off from the law of insurance bad faith. The beneficiary of a life insurance policy recovered vastly more than the amount of the benefits on a claim for bad faith denial against the insurer. See id. The insured's heirs sued to recover the excess over the amount of the policy proceeds on the theory that it was a windfall and that the insured had intended to endow the named beneficiary only with the proceeds. See id. The court refused to impose a constructive trust because there was no finding that the beneficiary abused the insured's confidence. See id. at 621 .

295. Factual issues regarding unjust enrichment such as whether the defendant made beneficial use of the plaintiff's resources are decided by the jury. See St. Paul Mercury Ins. Co. v. Meeks, 508 S.E.2d 646, 648 (Ga. 1998). Whether the plaintiff acted gratuitously in rendering services is also treated as a factual issue. See Kershaw v. Tracy Collins Bank \& Trust Co., 561 P.2d 683, 685 (Utah 1977) (citing Burton v. McLaughlin, 217 P.2d 566 (Utah 1950)).

296. See supra notes $155-60,179-83$ and accompanying text (discussing the doctrines of indefiniteness, impracticability, impossibility, frustration of purpose, mutual mistake, and public policy).

When there is a binding contract not breached by the defendant, the judge usually decides whether unjust enrichment has occurred. The judge acts as decision-maker in this instance because of the interaction of the rules in contract law that make contract interpretation an issue for the judge and the principle in restitution that " $[w]$ here there exists a valid express contract covering the subject matter, there can be no implied contract." Woodard v. Southwest States, Inc., 384 S.W.2d 674, 675 (Tex. 1964). McNeilab, Inc. v. North River Insurance Co., 645 F. Supp. 525 (D.N.J. 1986), illustrates the interaction of the two. See id. at 539. The manufacturer of Tylenol sued its liability insurer to recover its expenses incurred by recalling Tylenol after a tampering incident. See id. at 527-28. McNeilab relied on Leebov v. United States Fidelity Guaranty Co., 165 A.2d 82 (Pa. 1960), where the insured was allowed to recover mitigation expenses from its liability insurer. See McNeilab, 645 F. Supp. at 531-32. The district court rejected McNeilab's claim on a motion for summary judgment primarily on the ground that mitigation expenses were not within the scope of coverage. See id. at 530-47. It rejected a restitution claim, in part, based on the principle that restitution ought not be awarded to compensate a party who could have bargained for such protection. See id. at 547-49 \& n.24.

297. Restatement of the Law of Restitution $\S 26(1)$ (b) (1936).

298. See id. cmt. c. 
on the facts of each case. Nevertheless, the existence and nature of a mistake generally is treated as a question for the judge. ${ }^{299}$ Another obligation that arises in restitution is the duty to compensate a rescuer. ${ }^{300}$ The judge decides if a rescuer acted unofficiously and to protect a sufficient interest. ${ }^{301}$ The mapped parts of restitution closely

299. Earl v. Saks \& Co., 226 P.2d 340 (Cal. 1951), is a colorful illustration. See id. at $342,244-45$. Barbee sought to set aside a gift of his fur coat to Mrs. Earl on the grounds that the gift was fraudulently induced. Mrs. Earl and Saks had secretly agreed that Mrs. Earl would pay $\$ 1000$ of the $\$ 5000$ purchase price. See id. at 342-43. Barbee thought, however, that he had bought the coat for $\$ 4000$. The trial judge refused to void the gift. See id. at 343 . The California Supreme Court reversed, which implies that it thought that the question of Barbee's motive was not one on which it had to defer to the fact-finder. See id. at 347.

In not one of the cases collected by George Palmer in Law of Restitution, and collected by Lawrence Kaplan in the 1999 Supplement, is the question of whether a mistake is of the type for which the law provides relief put to the jury. See George E. Palmer, Law of Restitution §§ 18.1-18.6 (1978 \& Cum. Supp. No. 1 1999). Still, I could not find a statement of the proposition that the sufficiency of the mistake is an issue for the judge. In many of the cases cited by Palmer, the plaintiff is seeking an equitable remedy so the issue does not arise. See, e.g., Twyford v. Huffaker, 324 S.W.2d 403, 406 (Ky. 1958) (holding mutuality of mistake unnecessary as a basis for relief to a gift-giving grantor); White v. White, 190 N.E.2d 102, 104 (Mass. 1963) (relying on the equitable doctrine, the court found no need to decide whether the mistake was one of fact or law). Even when the plaintiff seeks a legal remedy, the issue of mistake has been treated as equitable in character. See Fitzgerald v. Nelson, 79 P.2d 254, 256 (Or. 1938). In some cases, the judge decides whether a mistake is of a type that merits relief by applying a rule. Some of these rules seem valid. Thus, Palmer states as a rule that, absent detrimental reliance, a donor's mistake about his or her being married to the donee is sufficient to set aside a gift. See Palmer, supra, § 18.3. Other rules are honored mostly in the breach. The "rule" that mistake of law is not grounds for relief seems to be of this character. Palmer cites several cases reversing gifts because of a mistake of law. See id. $\$ 18.6$. His treatment of the rule, however, may be influenced by his disdain for it. A search of mistaken-gift cases collected in the Appendix to section 26 of the Restatement of the Law of Restitution revealed only one case where the issue was put to the jury. See Restatement of the Law of Restitution $\$ 26$ A (1988); see also Deskovick v. Porzio, 187 A.2d 610, 613 (N.J. Super. Ct. App. Div. 1963) (submitting to the jury the question whether justice requires restitution where a son paid the expenses of his father's last illness in the mistaken belief that his father had no resources). This case belongs in a category of cases in which restitution is regularly given, according to Palmer. See Palmer, supra, § 18.4. In Yohe v. Yohe, $353 \mathrm{~A} .2 \mathrm{~d} 417$ (Pa. 1976), the majority treated the issue whether the donor's negligence might bar relief for mistake as a question for the judge, while stating that it was for the jury to say whether the donee had abused a confidential relationship. See id. at $420-21$.

300. See Cotnam v. Wisdom, 104 S.W. 164, 166 (Ark. 1907); Restatement of the Law of Restitution $\S \S 112-17$.

301. See McNeilab, 645 F. Supp. at 558 (rejecting claim by Tylenol's manufacturer against liability insurer for mitigation expenses incurred after a tampering incident); Trott v. Dean Witter \& Co., 438 F. Supp. 842, 845 (S.D.N.Y. 1977); Scoville v. Vail Inv. Co., 103 P.2d 662, 667 (Ariz. 1940). There are rules for some situations. For example, providing necessities to a third person is deemed officious unless the defendant breached a duty to provide the same. See Restatement of the Law of Restitution $\$ 113 \mathrm{cmt}$. f. The question whether there was an emergency or whether an action was "immediately necessary" has been treated as one of fact. See, e.g., Chase Manhattan Bank v. T \& N PLC, 905 F. Supp. 107, 123 (S.D.N.Y. 1995). 
resemble the economic torts. These mainly consist of categorical rules that do not ask for a normative judgment at the point of application. When a normative judgment is asked for, it is usually treated as a question for the judge.

It is controversial whether the law of restitution is open to novel claims of unjust enrichment that do not fit within the traditional categories. A related question is what general principle may cover such claims. Peter Birks, an English scholar and perhaps the leading restitution scholar in the common law world, has said that there is no general principle while not quite closing the door to novel claims.30 Gareth Jones, an English scholar and author of the leading treatise on the subject, has said that the law of restitution is open to novel claims but he has not tried to spell out the principle..$^{303}$ American scholars have yet to address these questions systematically. ${ }^{334}$ American courts are ahead of the scholars on this point for unjust enrichment has been found in situations that do not easily fit within the traditional categories. ${ }^{305}$ Whatever principle best explains these cases, that

302 See Birks, Introduction, supra note 285, at 18-19.

303. See Peter Birks, Misnomer, in Restitution: Past, Present and Future 1, 2-4 (W.R. Cornish et al. eds., 1998) [hereinafter Birks, Misnomer].

304. See Andrew Kull, Rationalizing Restitution, 83 Cal. L Rev. 1191, 1193-95 (1995). Kull is the reporter on a planned new Restatement of Restitution. Kull's goal in his article is to establish that restitution is an autonomous body of law conferring rights that should be organized around the concept of unjust enrichment. See id. at 1196-98. He never unpacks the concept of "unjust."

305. See Anderson v. DeLisle, 352 N.W.2d 794, 796 (Minn. Ct. App. 1984). Anderson had contracted to buy real estate from the defendant. He made substantial improvements on the property, expending $\$ 25,000$, before defaulting. See id. at 795 . The trial court granted judgment notwithstanding the verdict for the defendant, reasoning that the plaintiff could not recover absent mistake or fraud by the vendor. See id. at 796. The court of appeals reversed and reinstated a judgment for the plaintiff. It reasoned:

Fraud and mistake are not the only grounds for recovery under the theory of unjust enrichment. An action for unjust enrichment may be based on failure of consideration, fraud, mistake, and situations where it would be morally wrong for one party to enrich himself at the expense of another. In this case there was no mistake or fraud by the vendors. But, DeLisles stood silent and watched Anderson make extensive improvements to their property. They contracted to retain those improvements upon default knowing that because of Anderson's financial problems there was little or no chance that he could perform under the contract. In such a situation, the jury reasonably could find that equity and good conscience require DeLisles to compensate Anderson for the improvements.

Id. (citations omitted). Numerous cases pose claims that do not easily fit within the established categories. See Murdock-Bryant Constr., Inc. v. Pearson, 703 P.2d 1197, 1200 (Ariz. 1985) ("[D]efendant [an innocent beneficiary of a contractor's fraud] may be held liable on a quantum meruit theory to make restitution for benefits received when defendant was neither a party to the contract under which plaintiff rendered services nor a party responsible for the wrong which permitted plaintiff to rescind the contract and seek restitution."); Ninth Dist. Prod. Credit Ass'n v. Ed Duggan, Inc., 821 P.2d 788, 801 (Colo. 1991); In re Estate of Peck, 497 N.W.2d 889, 890 (lowa 1993) (considering a claim for restitution by the heirs of a woman against her widower on 
principle will operate much like Holmes's and Pollock's principle of prima facie tort. The principle will signal that the law is open to novel claims of unjust enrichment and it will provide a conceptual structure for addressing the normative issue of injustice.

Whatever that principle may be, it is for the judge and not the jury to decide what constitutes unjust enrichment in the first instance in a case for which there is no settled rule. It is well established that the judge decides whether there is an obligation in restitution when the facts are not in dispute. ${ }^{306}$ Some cases go further and hold that, even in a case where the facts are disputed, it is an error to put the question of what constitutes unjust enrichment to the jury under a general instruction. ${ }^{307}$ This position has been justified on the mistaken view

the theory that he reaped a windfall when she died shortly before the dissolution of their marriage); Stevens v. Stevens, 82 A.2d 418, $422-23$ (N.H. 1951) (drawing on the principle of unjust enrichment to justify compensating a son for his services in administering his father's assets under a voided transfer); In re Estate of Zent, 459 N.W.2d 795, 800-01 (N.D. 1990) (finding that a claim for a payment for services rendered should be rejected where it was conceded that the service provider did not expect to be compensated). Often novel claims are rejected on dubious categorical principles. See Davidson v. Davidson, 667 So. 2d 616, 621-22 (Miss. 1995) (rejecting a claim on the principle that to be unjust enrichment must be the product of a wrong); supra note 294 and accompanying text.

For a strong statement regarding the openness of the law to novel claims of unjust enrichment, see Jeffs v. Stubbs, 970 P.2d 1234, $1244-46$ (Utah 1998); see also H. Jefferson Powell, "Cardozo's Foot": The Chancellor's Conscience and Constructive Trusts, 56 Law \& Contemp. Probs. 7, 14-15 (1993) (concluding that the view that restitution will lie on general equitable principles has triumphed in the United States, and attributing this triumph to decisions by Cardozo mediated through the Restatement of Restitution).

306. There is much authority for this proposition. See, e.g., Bloomgarden v. Coyer, 479 F.2d 201, 211 (D.C. Cir. 1973) ("[W] here, as here, the essential facts are not in dispute, the question whether a quasi-contract should be erected is one of law."); State Dep't of Revenue, Child Support Enforcement Div. v. Wetherelt, 931 P.2d 383, 390 n.11 (Alaska 1997) (finding that where the facts are clearly established the issue becomes one of law).

307. See U.S. East Telecomms., Inc. v. US West Communications Servs., Inc., 38 F.3d 1289, 1301-02 (2d Cir. 1994). U.S. East involved a claim by a sub-subcontractor against a general contractor for work done after default by the sub-contractor. See id. at 1292-94. The sub-subcontractor alleged that the general contractor had represented that the subcontractor would be paid. See id. at 1294. The trial judge submitted the case to the jury on the following general charge:

In order to award East damages on the basis of unjust enrichment, you must

find that East has demonstrated by a preponderance of the evidence that one, West was enriched, two, the enrichment was at East's expense, and three, the circumstances are such that equity and good conscience required West pay East for the reasonable value of what it received.

Id. at 1296. The court of appeals affirmed but on the narrow ground that while the plaintiff could not normally require restitution for the services performed under contract, New York law made an exception when the party who benefited from the services made independent representations that the service provider would pay. See id. at 1298.

For a case endorsing giving the issue of unjust enrichment to the jury under a general standard, see Gulf Life Insurance Co. v. Folsom, 907 F.2d 1115, 1119-20 (11th Cir. 1990), and Gulf Life Insurance Co. v. Folsom, 349 S.E.2d 368, 372 (Ga. 1986). 


\section{that unjust enrichment is an equitable principle. ${ }^{305}$ And it has been}

The issue was whether a mistaken payment could be recovered. See Folsom, 349 S.E.2d at 370. The Eleventh Circuit referred the case to the Georgin Supreme Court to determine whether a mistaken payment could be recovered because of conflicting Georgia statutes on the issue. After the case came back to federal court, the Eleventh circuit stated:

From this discussion we discern that the equities to be considered by the jury are (1) the degree of negligence on the plaintiff's part in erroneously paying over the money, (2) the level of good faith with which the defendant acted in receiving and retaining the money, and (3) prejudice, i.e., whether the defendant's position has so changed that it would be unfair to require him to pay the money back. Essentially, what this means is that in an action for money had and received, where the plaintiff was negligent, the plaintiff is entitled to get his money back-unless the jury decides that he doesn't deserve it back or that the defendant deserves to keep it. Under this extremely flexible equation we find it impossible to say as a matter of law that a jury could never find that Folsom is entitled to keep the money wrongfully paid by Gulf.

Folsom, 907 F.2d at 1119.

308. North Dakota cases take the position that "[a] determination of unjust enrichment is necessarily a conclusion of law because it holds that a certain state of facts is contrary to equity." Estate of Zent, 459 N.W.2d at 798. In Zent, the court invoked this principle in reversing a decision of a lower court denying compensation to a woman who provided unpaid housekeeping services for several years to her companion while he suffered from Alzheimer's. See id. at 801 . The court held that the woman could recover though she testified that she had not expected her companion to pay her because of the extraordinary nature of the services. See id. at 800-01. In Albrecht $v$. Walter, 572 N.W.2d 809 (N.D. 1997), the court invoked the same principle in reversing a decision that it would unjustly enrich the other guarantors to enforce the obligation of a co-guarantor to pay his share of a debi because the other guarantors misled the co-guarantor about the prospects for the business when he made the guaranty. See id at 813 . The North Dakota Supreme Court decided that there had been no misrepresentation and that the co-guarantor should have known as well as the others the uncertain prospects of their restaurant. See id. at 813-15. The guarantors brought the co-guarantor into the venture to run the restaurant and promised him an equity interest to be purchased out of the profits. See id. at 811 . He was pushed out when the restaurant did not do as well as expected. See id. at 811-12. He then opened a successful competing restaurant. See id. at 812. Restitution has a long history on the law side of the docket. Claims in law for restitution of money using the writ of assumpit and the fiction of an implied promise appear in the early seventeenth century. See J.H. Baker, The Use of Assumpsit for Restitutionary Money Claims 1600-1800, in Unjust Enrichment 31, 31-35 (Eltjo J.H. Schrage ed., 1995). There is an acceptance of the use of the writ of assumpsit to undo unjust transactions generally in Moses v. Macferlan, 97 Eng. Rep. 676 (K.B. 1760) where Lord Mansfield concluded that a claim for money had and received would lie:

for money got through imposition, (express, or implied) or extortion; or oppression; or an undue advantage taken of the plaintifr's situation, contrary to laws made for the protection of persons under those circumstances. In one word, the gist of this kind of action is, that the defendant, upon the circumstances of the case, is obliged by the ties of natural justice and equity to refund the money.

Id. at 681 . Baker observes that during this period the trial judge determined whether a writ might be brought under a fictional promise and he would instruct a jury on what facts it might rule for the plaintiff. See Baker, supra, at 33-35. Because courts did not preserve them, judges' opinions did not become book law. Book law on the subject begins with Moses v. Macferlan where Lord Mansfield, who sat as the trial judge, decided that the plaintiff had strong claim on the equities and put the legal 
justified on the wooden view that it is a question of duty. ${ }^{309} \mathrm{~A}$ better argument is that it inheres in the very form and structure of the law of restitution. The law of restitution is largely composed of categorical rules that do not require a normative judgment at the point of application. The judge decides whether a claim may proceed when it falls on the boundary of one of the established doctrines. Logically, the judge should also decide wholly novel claims that are grounded on a more general principle of unjust enrichment.

The Colorado Supreme Court faced the question of whether there is a general principle of unjust enrichment and the question of the role of judge and jury in working out that principle in Ninth District Production Credit Assoc. v. Ed Duggan, Inc. ${ }^{310}$ Duggan supplied feed to a feedlot to which the Association provided credit. ${ }^{311}$ The Association had a security interest in the feedlot's receivables. ${ }^{312}$ Duggan was an unsecured creditor. ${ }^{313}$ The Association enabled the feedlot to continue operating though the lot was failing, and no warning was given to Duggan that there was little prospect he would be paid for the feed he provided. ${ }^{314}$ When the feedlot folded, Duggan sought restitution from the Association for the value of the feed. ${ }^{315}$ The trial court submitted the claim to the jury on an instruction that asked if "the Defendant... accepted the benefit under such circumstances that it would be inequitable for the Defendant ... to retain the benefit without payment of the reasonable value of the corn." "'316 The Colorado Supreme Court rejected the Association's argument that no claim could ever lie in restitution by an unsecured creditor against a secured creditor for the enhancement of the value of the secured collateral.317 It rejected such a categorical rule, reasoning that such a claim might well be just if the secured creditor "initiated or encouraged the transaction." ${ }^{118}$ But the court thought it wrong to

question of whether assumpsit would lie to the full court in Westminister. See id. at 56-57.

309. See Wanaque Borough Sewerage Auth. v. Township of W. Milford, 677 A.2d 747,752 (N.J. 1996) (reasoning that the duty defines the contract "in the case of quasicontract" and "[t] he scope of the duty is a question of law to be decided by the court").

310. 821 P.2d at 795-98.

311. See id. at 790.

312. See id.

313. See id.

314. See id. at 791.

315. See id. at 792-93.

316. Id. at 799. The instruction is difficult to interpret because parts of it read as if it were an instruction on an implied-in-fact contract claim. In particular, the judge stated that to find "an implied contract to pay for goods, you must find ... the Plaintiff delivered corn ... without a specific agreement as to compensation, but with the reasonable expectation that it would be paid the reasonable value of the corn by the Defendant ...." Id.

317. See id. at 795.

318. Id. 
submit the issue to the jury without some guidance.319 The court reasoned that "[a] jury cannot be presumed to understand the interrelation of the doctrine of unjust enrichment and the law of secured transactions and therefore must be apprised of how a seeming conflict between the two is to be resolved." 300

\section{ABUSE OF A CONFIDENTIAL RELATIONSHIP}

The doctrine of abuse of a confidential relationship is at the periphery of topics that themselves are at the periphery of the modern common law. Legal treatises tend to address the doctrine under the law of constructive trusts $\mathrm{s}^{321}$ or the law of restitution. .2 I close with this most peripheral of topics because it serves as a counterpoint to, and as a reinforcement of, some of the central themes of this Article. This is the only place in the common law where the jury traditionally has been given significant normative discretion in deciding what is appropriate conduct affecting only economic interests. I see nothing objectionable in this in principle. The jury ought to decide what is appropriate conduct in dealing with close family and friends because it is a matter of "principles of common honesty." But this useful doctrine is under assault on two fronts. Plaintiffs have tried to stretch it to cover ordinary commercial relationships. In response, judges have imposed categorical limitations, some of dubious merit. A possible to understanding the limitations of the doctrine is to understand that, in defining its scope, we are merely defining the field in which the question of what is inappropriate commercial conduct is for the jury to decide. Conduct that is found to fall outside the scope of the doctrine does not foreclose a judicial determination that it is inappropriate on more general principles.

The traditional definition of a confidential relationship is quite open-ended. ${ }^{323}$ This statement from a 1965 Kansas decision is

319. See id. at $798-801$.

320. Id. at 800 .

321. See George Gleason Bogert, The Law of Trusts and Trustees $\S 482$ (2d ed. 1978); see also Scott on Trusts \& 2.5 (William Franklin Fratcher ed., 4th ed. 1987) (discussing fiduciary relationships).

322 See Dan B. Dobbs, Dobbs Law Of Remedies $\S 10.4$, at 668 (2d ed. 1993). In English civil law, the concept of abuse of a confidential relationship originated in equity where something like it flowered in the law of constructive trusts in the seventeenth and early eighteenth centuries. See Gareth Jones, The Role of Equity in the English Law of Restitution, in Unjust Enrichment 149, 152-55 (Eltjo J.H. Schrage ed., 1995).

323. See Farmer City State Bank v. Guingrich, 487 N.E.2d 758, 763 (Ill. App. Ct. 1985 ) (finding that a plaintiff may establish a fiduciary relation by "the degree of kinship, disparity of age, health, mental condition, education and business experience between the parties, and the extent to which the allegedly servient party entrusted the handling of his business and financial affairs to the other and reposed faith and confidence in him" (citation omitted)). See also Kurth v. Van Horn, 380 N.W.2d 693 (Iowa 1986) : 
representative:

Whether or not a fiduciary relationship exists and whether or not it has been abused does, to a great extent, depend on the particular facts and circumstances of each individual case. This court has refused, for that reason, to give exact definitions or fix definite boundaries for that class of human relations commonly known as fiduciary which, based on principles of common honesty, require fair dealing between parties. $^{324}$

While the statement refers to fiduciary relationships, the factual context (the issue in the case was the fairness of an exchange between parent and child) makes clear that the court had in mind abuse of a confidential relationship. The hallmark of a fiduciary relationship is an undertaking to act on behalf of or to advise another person. ${ }^{325}$ Fiduciaries must be selfless in the tasks they undertake as a fiduciary. A person may pursue his own interests in dealing with a confidant, it is just that he may not pursue them too aggressively.

Inappropriate conduct in a confidential relationship also is loosely defined. A person doing business with a confidant must disclose

Some of the indicia of a fiduciary relationship include the acting of one person for another; the having and the exercising of influence over one person by another; the reposing of confidence by one person in another; the dominance of one person by another; the inequality of the parties; and the dependence of one person upon another. Because the circumstances giving rise to a fiduciary duty are so diverse, any such relationship must be evaluated on the facts and circumstances of each individual case.

Id. at 696 (citations omitted).

The standard of undue influence is similarly open-ended. For instance in Mullins $v$. Ratcliff, 515 So. 2d 1183 (Miss. 1987), the court stated:

Undue influence is a practical, non-technical conception, a common sense notion of human behavior.... [C]ommon sense counsels against rigid, inflexible multi-part tests, particularly as the parties our law saddles with proof of the negatives are laymen, not legal technicians. Better that the scope of equitable principles be imperfectly defined than that justice be overborne by the weight of artificial rules.

Id. at 1194; see also In re Estate of Gersbach v. Warren, 960 P.2d 811, 816 (N.M. 1998)

(finding that "[s]trict definitions are not necessarily useful analytical tools" in defining undue influence).

324. Wilkinson v. Cummings, 400 P.2d 729, 732-33 (Kan. 1965) (citation omitted).

325. See Restatement (Second) of Torts $\$ 874 \mathrm{cmt}$. a (1979). First National Bank of Meeker v. Theos, 794 P.2d 1055 (Colo. Ct. App. 1990), is a fairly well-reasoned decision focusing on the importance of identifying the defendant's undertaking to act for or advise the plaintiff as the source of the duty. Unfortunately, this is in reference to abuse of a confidential relation. Usually, courts define fiduciary relationships in broader terms. For example, the Kurth court stated:

A 'fiduciary relation' arises whenever confidence is reposed on one side, and domination and influence result on the other; the relation can be legal, social, domestic, or merely personal. Such a relationship exists when there is a reposing of faith, confidence and trust, and the placing of reliance by one upon the judgment and advice of the other.

380 N.W.2d at 695-96 (quoting Black's Law Dictionary 564 (5th ed. 1979). 
material information. ${ }^{326}$ More generally, a person who does business with a confidant has the burden of showing the fairness of the transaction. ${ }^{327}$ A person may not invoke the statute of frauds or insist upon other legal formalities as a defense when sued by a confidant. ${ }^{23}$ An informal understanding between confidants on the sharing of wealth may lay the basis for a restitution claim. ${ }^{32}$ Restitution may be required within a confidential relationship for wealth acquired through the relationship even in the absence of an understanding on sharing. ${ }^{330}$ In addition, a person may not disclose secrets learned from

326. See Restatement (Second) of Contracts § 161(d) (1981).

327. See Murphy v. Wakelee, 721 A.2d 1181, 1183 (Conn. 1998); cf. Tidball v. Hetrick, 363 N.W.2d 414, 417 (S.D. 1985) (noting that due to the high degree of confidence and trust in an attorney-client relationship, attorney compensation contracts are to be closely scrutinized by the court).

328. See Cochran v. Murrah, 219 S.E.2d 421, 423 (Ga. 1975). A farm laborer asserted a claim of confidential relationship in order to overcome a release that he had signed but not read. See id. at 422 .

329. Small v. Badenhop, 701 P.2d 647 (Haw. 1985), illustrates the elasticity of the concept of confidential relationship in a suit for restitution. The plaintiffs owned two parcels of land in Hawaii, one large, one small, subject to debt. They discussed subdividing the combined parcels with the defendants, their long-time friends. See id. at 650-51. When the plaintiffs were unable to make a balloon payment due on the debt, the defendants offered to step in and informally promised to protect the plaintiffs' equity. See id. at 651 . The defendants took title to the parcels, paying the balance due on the note. See id. Later the parties discovered that the property could not be subdivided. See id. at 652 . The defendants built a home on the property that their son took over. See id. at 653 . The parties remained friends for years until the plaintiffs tried to formalize their understanding and the defendants denied the plaintiffs' interest in the property. See id. at 652-53. There is a strong statement of the flexibility of the law in this area:

Where 'confidence has been reposed and betrayed' we have not allowed technical considerations to stand as barriers to equitable relief.... [T] term fiduciary or confidential relation ... is a very broad one. It has been said that it exists, and that relief is granted, in all cases in which influence has been acquired and abused-in which confidence has been reposed and betrayed. The origin of the confidence and the source of the influence are immaterial. The rule embraces both technical fiduciary relations and those informal relations which exist whenever one man trusts in and relies upon another. The only question is, does such a relation in fact exist?

Id. at 655 (citations omitted). Russell v. Douglas, 138 So. 2d 730 (Miss. 1962), is similar. A nephew and his wife owned property subject to a mortgage that was in default. See id. at 731. His aunt paid off the mortgage, which was approximately onethird the value of the property, and she took title. See id. at 732. The nephew and his wife claimed that the Aunt did so to accommodate them. See id. at 732-33. They explained the lack of documentation by the close relation with the aunt, who came to Mississippi to help the nephew's mother before she died. See id. The nephew brought the suit after the aunt tried to evict him. See id. at 732. The court imposed a constructive trust on the aunt on the basis of a confidential relation. See id. at 733.

330. Sinclair v. Purdy, 139 N.E. 255 (N.Y. 1923), is famous for Cardozo's epigram "[i]t is not the promise only, nor the breach only, but unjust enrichment under cover of the relation of confidence, which puts the court in motion." Id. at 258. A brother had transferred money to his sister to hide it from his creditors. See id. at 256 . The decision imposes a constructive trust on the sister. See id. at 259. A common claim of this sort often arises between unmarried cohabitants. See, e.g., Bramlett v. Selman, 597 S.W.2d 80, 80 (Ark. 1980) (imposing a constructive trust to fairly divide property 
a confidant. ${ }^{331}$ However, it probably is best to keep the obligation not to disclose confidential information separate from other obligations in confidential relationships because it is based more on the character of the information than the character of the relationship. For example, it can be a wrong to disclose confidential information about a stranger.

According to the great weight of authority, the questions of the existence and breach of a confidential, or an informal fiduciary, relationship are for the jury to decide. ${ }^{332}$ There is some contrary authority. ${ }^{333}$ Some states constrain the discretion of the decisionmaker by requiring that the plaintiff establish the existence of a confidential or an informal fiduciary relationship by clear and

between gay lovers); Williams v. Lynch, 666 N.Y.S.2d 749, 749 (N.Y. App. Div. 1997) (finding a confidential relationship between unmarried cohabitants in order to justify the imposition of a constructive trust, allowing the recovery of the value of money and labor contributed by one of the cohabitants to improving the house and grounds). For a case rejecting such a claim on the theory that restitution lies only if property is obtained by commission of a wrong, see Doe v. Roe, 475 S.E.2d 783, 786-87 (S.C. Ct. App. 1996).

331. See Wilson v. IBP, Inc., 558 N.W.2d 132 (Iowa 1996); see also infra notes 34750 and accompanying text. On breach of confidence as a tort, see generally Susan M. Gilles, Promises Betrayed: Breach of Confidence as a Remedy for Invasions of Privacy, 43 Buff. L. Rev. 1, 2 (1995) [hereinafter Gilles, Promises Betrayed] (discussing the meaning of "breach of confidence and whether it will prove a viable remedy for those who seek to recover for the unwanted publication of private facts"). See also Scott L. Fast, Comment, Breach of Employee Confidentiality: Moving Toward a Common-Law Tort Remedy, 142 U. Pa. L. Rev. 431, 431 (1993) (arguing that aggressive judicial law-making is needed rather than waiting for legislatures to react to breach of employee confidentiality).

332. See In re Daisy Syst. Corp., 97 F.3d 1171, 1178 (9th Cir. 1996) (applying California law and concluding that "the existence of a fiduciary relation is a question of fact which properly should be resolved by looking to the particular facts and circumstances of the relationship at issue"); Moses v. Diocese of Colorado, 863 P.2d 310, 321 (Colo. 1993) (en banc); Dawson v. Hummer, 649 N.E.2d 653, 663 (Ind. Ct. App. 1995) (holding that whether a confidential relationship exists, for purposes of a constructive fraud claim, is a question of fact to be determined by the fact-finder); Kurth v. Van Horn, 380 N.W.2d 693, 695-96 (Iowa 1986); Kondelik v. First Fidelity Bank, 857 P.2d 687, 693 (Mont. 1993) (holding existence of a fiduciary relation is a question of fact while distinguishing a finding of covenant of good faith and fair dealing); Davis v. Church of Jesus Christ of Latter Day Saints, 852 P.2d 640, 646 (Mont. 1993) (holding that whether confidential relation existed between church and member cannot be resolved on summary judgment); Mackintosh v. California Fed. Sav. \& Loan Ass'n, 935 P.2d 1154, 1160 (Nev. 1997); L.C. v. R.P., 563 N.W.2d 799, 801 (N.D. 1997); Mancini v. Gorick, 536 N.E.2d 8, 10 (Ohio Ct. App. 1987); Allen Realty Corp. v. Holbert, 318 S.E.2d 592, 595 (Va. 1984) (finding an existence of an informal fiduciary relationship is a question of fact).

333. See Long v. Lampton, 922 S.W.2d 692, 697 (Ark. 1996) (holding that, under these facts, existence of a fiduciary duty was a question of law on the reasoning that questions of duty are for the court). Much of the contrary authority involves nondisclosure, where the issue of duty generally is treated as one for the judge. See Mallon Oil Co. v. Bowen/Edwards Assocs., 940 P.2d 1055, 1059 (Colo. App. 1997); Garrett v. BankWest, Inc., 459 N.W.2d 833, 839 (S.D. 1990); First Sec. Bank v. Banberry Dev. Corp., 786 P.2d 1326, 1329 (Utah 1990); In re Estate of Lecic, 312 N.W.2d 773, 779 (Wis. 1981). 
convincing evidence. ${ }^{34}$ Judges have begun to lay down categorical rules to preclude finding either an informal fiduciary relationship or a confidential relationship in certain circumstances. One such rule precludes finding an informal fiduciary or confidential relationship when the parties had no relationship prior to the dealings in which the alleged breach of trust occurred. ${ }^{335}$ Another such rule precludes the finding of an informal fiduciary or confidential relationship when the parties' relationship stands entirely on a business footing.."35

Such decisions respond to a spate of claims that relationships founded entirely on a business footing are confidential. ${ }^{m}$ They allege

334. This is the rule in Illinois. In Illinois, if a relationship is one which is not fiduciary as a matter of law, it may still be so as a matter of fact, but only if the party alleging the relationship presents specific, "clear and convincing evidence" of "the degree of kinship, disparity of age, health, mental condition, education and business experience between the parties, and the extent to which the allegedly servient party entrusted the handling of his business and financial affairs to the other and reposed faith and confidence in him." Farmer City State Bank v. Guingrich, 487 N.E.2d 758, 763 (IIl. App. Ct. 1985) (citation omitted). Earlier cases apply a very high evidentiary standard indeed. For instance, in Kolze v. Fordtran, 107 N.E.2d 686 (Ill. 1952), the court stated that:

The relationship may exist as a matter of law between attorney and client, guardian and ward, principal and agent, and the like, or it may be moral, social, domestic, or even personal. Where the relationship does not exist as a matter of law or is sought to be established by parol evidence, the proof must be clear, convincing, and so strong, unequivocal, and unmistakable as to lead to but one conclusion.

Id. at 690 (citation omitted). See also Clark v. Clark, 76 N.E.2d 446, 449 (Ill. 1947) (requiring clear and conclusive evidence to establish a constructive trust); Stewart v. Sunagel, 68 N.E.2d 268, 271 (IIl. 1946) (establishing a clear and convincing standard for a fiduciary relationship between parent and child).

335. See Nicholson v. Ash, 800 P.2d 1352, 1355 (Colo. Ct. App. 1990); Schlumberger Tech. Corp. v. Swanson, 959 S.W.2d 171, 177 (Tex. 1997).

336. See Northeast Gen. Corp. v. Wellington Adver., Inc., 624 N.E.2d 129, 131 (N.Y. 1993) ("If the parties find themselves or place themselves in the milieu of the 'workaday' mundane marketplace, and if they do not create their own relationship of higher trust, courts should not ordinarily transport them to the higher realm of relationship and fashion the stricter duty for them.").

337. For successful claims, see Mancuso v. United Bank of Pueblo, 818 P.2d 732 (Colo. 1991). A mother who put money in a joint account with her deadbeat son successfully brought suit against a bank under a variety of theories, including abuse of a confidential relationship, when the bank applied funds in the account against the son's debts. See id. at 735-36; see also Stokes v. Henson, 265 Cal. Rptr. 836, 836 (Ct. App. 1990) (finding an abuse of a confidential relationship between an investment advisor and client); Paine, Webber, Jackson \& Curtis, Inc. v. Adams, 718 P.2d 508, 516-18 (Colo. 1986) (discussing extensively the circumstances tending to create a fiduciary relation between securities broker and customer); Peoples Bank \& Trust Co. v. Lala, 392 N.W.2d 179, 186-89 (Iowa Ct. App. 1986) (finding an abuse of a confidential relationship when bank pressured wife of ill debtor to sign away homestead rights); Nie v. Galena State Bank \& Trust Co., 387 N.W.2d 373, 376 (Iowa Ct. App. 1986) (finding abuse of a confidential relationship when bank officer failed to disclose personal interest in property for which borrower was securing financing); Mackintosh v. California Fed. Sav. \& Loan Ass'n, 935 P.2d 1154, 1160 (Nev. 1997); Mancini v. Gorick, 536 N.E.2d 8, 10 (Ohio Ct. App. 1987) (finding an abuse of a confidential relationship when seller of property also served as architect and 
abuse in a decision to breach a contract, sever a relationship, or some other act showing indifference to the interests of the complaining party. ${ }^{338}$ They also seek punitive damages. ${ }^{339}$ These claims push the doctrine out in three directions: in scope from personal relations to business relations; in substance from guarding against self-enrichment to guarding against neglect; and in remedy from disgorgement of gain to compensation and punishment in excess of disgorgement.

Categorical limitations on the doctrine are inevitable given the pressure to expand it. The question is, what limits? An important first step is to distinguish a confidential relationship from an informal

engineer).

A series of Illinois cases illustrate the evolution of the concept from one of equity or restitution within the family to something approaching a concept of economic negligence. A half century ago, plaintiffs usually invoked the concept in suits seeking a constructive trust or to set aside a conveyance. The relations all arose within the family. See Kolze, 107 N.E.2d at 690; Stone v. Stone, 94 N.E.2d 855, 858 (Ill. 1950); Clark, 76 N.E.2d at 449-50; Stewart v. Sunagel, 68 N.E.2d 268, 271 (Ill. 1946). In Kester v. Crilly, the issue was whether a constructive trust might be imposed to enforce an oral promise to convey land notwithstanding the statute of fraud, which in Illinois is done only if the parties stand in a fiduciary relationship. See 91 N.E.2d 419, 423 (Ill. 1950); see also Farmer City State Bank, 487 N.E.2d at 762-64 (considering guarantors invocation of an informal fiduciary relationship as a basis for a duty in a negligence claim against a bank for alleged errors in preparing a guarantee agreement as well as the basis for a constructive fraud claim).

338. Many cases have rejected claims by borrowers against banks to recover a loss because the banks allegedly failed to warn about, or misrepresented, the risks in a transaction for which the banks provided financing. See Dugan v. First Nat'l Bank, 606 P.2d 1009, 1015 (Kan. 1980) (stating that existence of a fiduciary relationship is normally a question of fact, but holding that there was no such relationship as a matter of law between bank and borrower where bank did not act as financial advisor); Brae Asset Fund, L.P. v. Adam, 661 A.2d 1137, 1140 (Me. 1995) (holding that no confidential relationship existed between retired accountant and bank who had shared business interests); Ed Schory \& Sons, Inc. v. Society Nat'l Bank, 662 N.E.2d 1074, 1082 (Ohio 1996) (stating that "advice given by a creditor to a debtor in a commercial context in which the parties deal at arms' length, each protecting his or her respective interests, is insufficient to create a fiduciary relationship"); Indermill v. United Sav., 451 N.E.2d 538, 541 (Ohio Ct. App. 1982) (holding that the bank was not in a confidential relationship with the buyers who borrowed money from it). Some cases reject what are in essence claims of negligent misrepresentation against auditors or accountants not employed by the plaintiff. See Standard Chartered PLC v. Price Waterhouse, 945 P.2d 317, 334-36 (Ariz. Ct. App. 1996) (finding no fiduciary relationship between auditor and firm that relied upon its reports because plaintiff could have sought information elsewhere). Some cases reject what are in essence wrongful termination claims. See Crim Truck \& Tractor Co. v. Navistar Int'l Transp. Corp., 823 S.W.2d 591, 595-97 (Tex. 1992).

339. See Gergen, Cautionary, supra note 220, at 1249-58 (tracing the development of the tort of bad faith breach in Texas, which descended from the concept of a confidential relationship). For a more sympathetic account of this line of cases, see Eileen A. Scallen, Promises Broken vs. Promises Betrayed: Metaphor, Analogy, and the New Fiduciary Principle, 1993 U. Ill. L. Rev. 897, 897-980. Courts often define the category of contracts for which bad faith breach is a tort as those involving special relationships of trust and confidence. Scholars understand these cases as creating an independent tort of bad faith breach. Whether a contract is in the category involving special trust and confidence is an issue for the judge. 
fiduciary relationship. Some limitations can apply only to confidential relations..$^{340}$ While it leaves some injustices uncovered, ${ }^{\text {HI }}$ we can live with a categorical rule that strangers doing business together one time cannot stand in a confidential relationship. Usually people do not trust strangers in the same way they trust close family and friends. It is not unheard of for there to be an informal understanding between

340. Separating the concepts clarifies the issue when we ask what obligations a fiduciary has in dealing with his principle outside his capacity as a fiduciary. The questions then are whether the lawyer stands in a confidential relationship and when obligations attach. A lawyer may drive a hard bargain in negotiating a fee with a new client, for example, because he is not at that moment acting as a fiduciary or a confidant. A lawyer should also have the ability to deal at arms' length with a client in matters outside the scope of his representation so long as his client is aware that they are dealing at arms' length and that the lawyer does not exploit information gained through the representation.

New York cases on the obligations of a publisher to an author illustrate the virtue of particularizing the content of fiduciary obligation. Early New York cases characterized the relation between composer and publisher as fiduciary in nature to allow the composer to sue for infringement when a publisher would not. See Manning v. Miller Music Corp., 174 F. Supp. 192, 195-96 (S.D.N.Y. 1959). They would also allow a composer to sue a publisher for infringement. See Nelson v. Mills Music, Inc., 278 A.D. 311, 312 (N.Y. App. Div. 1951). Later cases recognize that a publisher is not under a fiduciary duty in all dealings with the author. The leading case is Van Valkenburgh, Nooger \& Neville, Inc. v. Hayden Publ'g Co., 281 N.E.2d 142 (N.Y 1972), which allowed a contract claim against a publisher for failure to use his best efforts in promoting a book, but held that there is no tort claim because the relation is not fiduciary. See id. at 145; see also Mellencamp v. Riva Music Ltd., 698 F. Supp. 1154, 1159-60 (S.D.N.Y. 1988) (holding that the conventional publisher-author arrangement is not a fiduciary relationship per se).

Separating the concepts also makes it possible to analogize an informal fiduciary relationship to an implied-in-fact contract. An informal fiduciary relationship is simply an implied-in-fact contract of agency. The analogy suggests that the jury should play a circumscribed role in finding informal fiduciary relationships. The question that the judge should put to the jury is whether the parties had an apparent understanding that one party would act on the behalf of the other or advise the other. See First Nat'l Bank of Meeker v. Theos, 794 P.2d 1055, 1061-62 (Colo. 1990) (requiring such an instruction).

341. See Zimpel v. Trawick, 679 F. Supp. 1502, 1503-04 (W.D. Ark. 1988). The defendant bought the plaintiff's mineral rights at a bargain price because he knew, and the plaintiff did not, that a productive well had been drilled on an adjoining property. See id. The court found there was a duty to disclose because the plaintiff was unsophisticated, old, and infirm (she negotiated on oxygen), the land was 300 miles away, and the defendant had made vague statements about how poorly the oil business was in the area. See id. at 1510-11. Alan Strudler makes this case the centerpiece of an argument that nondisclosure is best explained from a deontological perspective, to wit it protects "advantages bargainers deserve for bringing valuable information to the bargaining table." Alan Strudler, Moral Complexity in the Law of Nondisclosure, 45 UCLA L. Rev. 337, 340 (1997). His rationalization of Zimpel is cutesy: he says the case poses a moral paradox because while the plaintiff had a right not to be taken advantage of, the defendant had a right to exploit the information he obtained lawfully. See id. at 379-84. According to Strudler, the defendant should lose because the defendant created this moral paradox. See id. The defendant could have avoided his unfair advantage had he demanded that the plaintiffs able brother be present during the negotiations. See id. 
strangers that one will act as the other's agent in a business deal. ${ }^{342}$ Further, it is sensible to limit the concept of abuse of a confidential relationship to exploitation of trust for personal gain because a person who exploits the trust of family or friends to profit himself behaves worse than a person who inadvertently causes an economic injury to family or friends. ${ }^{343}$

This limitation can be imposed in two ways. One way is to limit the remedies for abuse of a confidential relationship to rescission and restitution or to estoppel. The other way is to allow the recovery of losses but to define the wrohg in a manner that requires that the wrongdoer have sought personal gain from his alleged misconduct. ${ }^{344}$ It is too late and probably a mistake to eliminate the tort remedy of compensatory damages for breach of a fiduciary duty.

A downside to limiting the scope of the concept of abuse of a confidential relationship and separating it from the concept of informal fiduciary duty is that some cases will fall through the cracks thereby opened in the law. A recurring case of this sort involves clergymen who prey sexually upon members of their congregation. Several courts have held this to be a breach of fiduciary duty or an abuse of a confidential relationship. ${ }^{345}$ It is odd to describe the priest's sin as exploiting trust for personal gain. Certainly restitution is an inadequate remedy. The relationship of priest to parishioner is not that of a family member or friend, though neither is it a business

342. Jones v. Runft, Leroy, Coffin \& Matthews, Chartered, 873 P.2d 861 (Idaho 1994), illustrates how a one-time relationship can be an informal fiduciary relationship. The defendant, an attorney, represented a venture that borrowed money from the plaintiff. See id. at 864 . The plaintiff gave the funds to the attorney to hold until certain conditions were met, one being the assignment of a partnership interest as security. See id. The attorney negligently directed that the funds be disbursed though this condition was not met. See id. The plaintiff-lender sued the attorney after the borrower defaulted and the security turned out to be non-existent. See id. at 865 .

343. For a case finding neglect of the interests of another to be abuse of a confidential relationship, see Lowery v. Guaranty Bank \& Trust Co., 592 So. 2d 79, 82 (Miss. 1991). The Lowery court found evidence to possibly hold the bank negligent when it failed to either procure life insurance or advise the debtor that he needed to do so.

344. See Barger v. McCoy Hillard \& Parks, 488 S.E.2d 215, 224 (N.C. 1997) (holding that in order to maintain claim for constructive fraud the plaintiff must show that the defendant exploited the plaintiff's trust to benefit himself).

345. See Davis v. Church of Jesus Christ of Latter Day Saints, 852 P.2d 640, 646 (Mont. 1993) (stating that breach of a fiduciary duty by a priest depends upon the existence of a "special relationship" with the congregation member); F.G. v. MacDonell, 696 A.2d 697, 704 (N.J. 1997) (noting many cases of breach of fiduciary duty and stating oddly that "[u]nlike an action for clergy malpractice, an action for breach of fiduciary duty does not require establishing a standard of care and its breach. Establishing a fiduciary duty essentially requires proof that a parishioner trusted and sought counseling from the pastor. A violation of that trust constitutes a breach of the duty." (quotation omitted)); see also Nally v. Grace Community Church, 204 Cal. Rptr. 303, 307-08 (Ct. App. 1984) (allowing the plaintiff to prevail instead on a claim of intentional infliction of emotional distress). 
relationship. Nor is the priest a fiduciary in the sense of being a person who acts on behalf of or advises his congregation, though he is expected to be personally disinterested. Judges might deal with recurrent cases like these by creating another category of fiduciarylike relationships to cover people in positions where they are supposed to serve others in a disinterested fashion without acting on another person's behalf or providing advice (the teacher-student relationship also could be put in this category).

Unusual cases will undoubtedly continue to fall through the cracks. In Wilson $v . I B P$, Inc. ${ }^{346}$ an employer hired a nurse to coordinate medical treatment of employees for workplace injuries. ${ }^{30}$ The plaintiff claimed that the nurse violated a fiduciary duty or abused a confidential relationship when she falsely told a physician, who had prescribed bed-rest, that the employee continued normal activities at home. ${ }^{348}$ The nurse did this, it was alleged, to induce the physician to say that the employee could return to light work. ${ }^{39}$ Thus, the relationship did not fit into the mold of a fiduciary relationship. ${ }^{30}$ Nor can the relationship be classified as a confidential relationship if such a relationship must be grounded outside the workplace. As tried, the case is not very interesting because the plaintiff alleged and the jury found that the nurse lied about his condition.3.31 It is only a case of over-pleading. The case is interesting if we assume that the nurse negligently misrepresented the employee's condition. The employee could not sue for misrepresentation because he did not rely on the misrepresentation. He could still sue, however, for tortious interference with his benefits if the benefits were not paid by his employer. ${ }^{352}$ But, there is something to be said for analyzing the case under a heading that emphasizes the special relationship of trust and confidence that may exist between an injured person and a healer.

The answer to the objection that limiting the scope of the doctrine may leave some injustices unrequited is that the limitations only serve to delineate the cases in which it is for the jury, and not the judge, to decide what is inappropriate conduct. Outside the context of confidential relationships a judge might still decide conduct is inappropriate under the general principles of prima facie tort and unjust enrichment. Within confidential relationships, the duty

346. 558 N.W.2d 132 (Iowa 1996).

347. See id. at 136.

348. See id.

349. See id. at 143.

350. See id.

351. See id. at 141. This was covered by a slander claim. See id. at 139. The jury awarded $\$ 4000$ in actual damages and $\$ 15,000,000$ in punitive damages, which was reduced by the trial judge to $\$ 100,000$ in punitive damages. See id. at 136 .

352. Generally, an agent is privileged to interfere in the contracts of his principal so long as his actions are not motivated by self-interest. See Gergen, Tortious Interference, supra note 7, at 1197. 
imposed can then be understood as being similar to the duty of reasonable care in negligence. It is not wrong per se to profit from dealings with kith and kin or vulnerable others who trust us, just as it is not wrong per se to act in a way that foreseeably harms others. But it is wrong enough to put the issue of the morality of the conduct to the jury.

\section{CONCLUSION}

A famous old British negligence case has a nice description of the morality of negligence law:

The liability for negligence... is no doubt based upon a general public sentiment of moral wrong doing for which the offender must pay. But acts or omissions which any moral code would censure cannot in a practical world be treated so as to give a right to every person injured by them to demand relief.... The rule that you are to love your neighbour becomes in law, you must not injure your neighbour; and the lawyer's question, Who is my neighbour? receives a restricted reply. ${ }^{353}$

By this description, negligence law is neither a system of social engineering nor an expression of abstract moral principles. It is an expression of ordinary morality. In the United States, the bedrock principle in negligence can be put this way: if a person acts in a way that foreseeably physically harms his neighbor or his neighbor's property, and if the appropriateness of his conduct is at all in doubt, then his neighbors will decide whether he should pay for the harm he caused. The statement also reminds us that people are judged under the standards of ordinary morality only in some spheres of their lives, and that the boundaries of those spheres is itself a "lawyer's question." This is not to imply that ordinary morality does not influence the law in other spheres. Of course it does, but judges have other concerns in mind that mediate the influence of ordinary morality. 354

The doctrine of abuse of a confidential relationship, at least as it once was understood, could be described in the same way: the doctrine is based upon general public sentiment of fairness that will not permit the offender to deal unfairly with others. But sharp dealings, which any moral code would censure, cannot in a practical

353. See Donoghue v. Stevenson, 1932 App. Cas. 562, 580 (appeal taken from Scot.).

354. Cardozo exemplifies a judge who strove to ground decisions on contemporary morality while working within the framework of the law. See Powell, supra note 305, at 22-24. Powell concludes the essay on a skeptical note for he observes that "Cardozo assumed the existence of a [shared] moral tradition, within the legal profession and in society generally." Id. at 26 . Powell thinks society has lost sight of that moral tradition, if it ever existed. 
world be treated so as to give a right to demand relief to every person who feels sorely treated. The rule that you are to deal fairly with others becomes in law that you are to deal fairly with family and friends who trust you by not trying to profit from their weakness. The doctrine is changing as courts respond to efforts to stretch it. In this tug of war we are in danger of losing sight of the important principle that it is a question of ordinary morality how one should deal with close family and friends.

Commercial law now stands at a crossroad because of the shift in contract law from rules to standards, along with the emergence of non-categorical standards of conduct and obligation in tort and restitution. One path courts might take is to give juries much the same power in administering these standards that they have in administering the law of negligence. On this path, the legal morality of the marketplace will become more nearly an expression of ordinary morality. Fear of the jury and dislike of legal uncertainty may impel courts down a different path. Judges may embrace rules that reach recurrent immoralities and reject or cut back doctrines that make it possible to reach unusual ones. On this path, the gap will grow between legal morality and ordinary morality. There is no right or wrong path. How could there be when what lies in balance is the desire to do what is just in the immediate case and the desire that the law be certain? My view is that courts should blaze a path somewhere between these two. On this path we would recognize that rules are the dominant but not the exclusive measures of the law's morality in the marketplace. We would also encourage and enable judges to decide what is just in cases that are not reducible to rules. 
Notes \& Observations

HeinOnline -- 68 Fordham L. Rev. 486 1999-2000 